\title{
Mechanisms of Resistance to Photodynamic Therapy
}

\author{
Adriana Casas ${ }^{a,}{ }^{*}$, Gabriela Di Venosa ${ }^{a}$, Tayyaba Hasan ${ }^{b}$, and Alcira Batlle ${ }^{a}$ \\ aCentro de Investigaciones sobre Porfirinas y Porfirias (CIPYP). CONICET and Hospital de \\ Clínicas José de San Martín, University of Buenos Aires. Córdoba 2351 1er subsuelo; Ciudad de \\ Buenos Aires, $\mathrm{CP}=1120 \mathrm{AAF}$, Argentina \\ bWellman Laboratories of Photomedicine WEL-224, Department of Dermatology, Massachusetts \\ General Hospital, Harvard Medical School, 55 Fruit Street, Boston, MA 02114, USA
}

\begin{abstract}
Photodynamic therapy (PDT) involves the administration of a photosensitizer (PS) followed by illumination with visible light, leading to generation of reactive oxygen species. The mechanisms of resistance to PDT ascribed to the PS may be shared with the general mechanisms of drug resistance, and are related to altered drug uptake and efflux rates or altered intracellular trafficking. As a second step, an increased inactivation of oxygen reactive species is also associated to PDT resistance via antioxidant detoxifying enzymes and activation of heat shock proteins. Induction of stress response genes also occurs after PDT, resulting in modulation of proliferation, cell detachment and inducing survival pathways among other multiple extracellular signalling events. In addition, an increased repair of induced damage to proteins, membranes and occasionally to DNA may happen. PDT-induced tissue hypoxia as a result of vascular damage and photochemical oxygen consumption may also contribute to the appearance of resistant cells.
\end{abstract}

The structure of the PS is believed to be a key point in the development of resistance, being probably related to its particular subcellular localization.

Although most of the features have already been described for chemoresistance, in many cases, no cross-resistance between PDT and chemotherapy has been reported. These findings are in line with the enhancement of PDT efficacy by combination with chemotherapy. The study of cross resistance in cells with developed resistance against a particular PS challenged against other PS is also highly complex and comprises different mechanisms.

In this review we will classify the different features observed in PDT resistance, leading to a comparison with the mechanisms most commonly found in chemo resistant cells.

\section{Keywords}

chemoresistance; cross resistance; PDT; photodynamic therapy; photosensitizer; resistance; apoptosis; photosensitizers; mechanisms; porphyrins; MDR

\section{INTRODUCTION}

Photodynamic therapy (PDT) involves the administration of a photosensitizer (PS) either systemically or locally, followed by illumination with visible light [1,2]. The PS absorbs light and, in the presence of oxygen, transfers the energy, producing cytotoxic oxygen species [3].

\footnotetext{
*All correspondence and proofs should be sent to: Dr. Adriana Casas, Viamonte 1881 10A, 1056 Buenos Aires, Argentina., Tel: 5411 5950 8346, Fax:: 54114811 7447., adriana@qb.fcen.uba.ar.
} 
Unlike chemotherapy and radiotherapy, PDT involves the combination of two agents: light and the PS. It is possible to obtain differences in the level of resistance when it is expressed in terms of fixed PS concentration and when it is expressed in terms of fixed light dose [4]. Some authors have increased drug dose or drug dose exposure $[4,5]$ or light dose $[6,7]$ during the induction of resistance, and in both cases high levels of resistance have been found.

The mechanisms of resistance ascribed to the PS may be shared with general mechanisms of drug resistance, and may be related to: (i) different uptake rate or efflux, (ii) altered intracellular trafficking of the drug, (iii) decreased drug activation, and (iv) increased inactivation of drug.

When the photoactivation of the PS occurs, reactive oxygen species are formed [3], and during a first stage, an increased inactivation of toxic species can occur via antioxidant enzymes [8, 9]. In addition, heat shock proteins (HSPs) play a role as intra-cellular chaperones for other proteins, folding and assisting in the establishment of proper protein conformation, preventing unwanted protein aggregation and helping to stabilize partially unfolded proteins [10] and thus help to recover from PDT damage. In a second step after photodamage, an increased repair of drug induced damage to proteins, membranes and even DNA may happen. At this stage, induction of stress response genes occurs after PDT, resulting in modulation of proliferation and cell detachment and inducing survival pathways among other multiple extracellular signaling pathways [11].

PDT resistant cell lines have only been isolated in vitro, and usually the magnitude of resistance obtained with PDT protocols is less than that reported for most drug-resistant cell lines [6]. Cell lines from multiple PDT-treated tumors have not been yet isolated. However, in vivo, other mechanisms related to host-drug or host-tumor interactions may be relevant.

In 1991, Luna and Gomer [6] isolated cell lines resistant to PDT. RIF-1 fibrosarcoma cells were exposed to two protocols of Photofrin II (PII)-PDT: short exposure (initial injury associated primarily with the plasma membrane) and long exposure to PII-PDT (associated with damage to organelles and enzymes). In both protocols, the resistant variants displayed a stable level of photosensitization, and a 2.5- to 3.0- $\log$ and 1.2- to 1.5-log increase in survival respectively at the highest light doses. In the same year, Singh et al. [5] isolated and characterized two different clones originated from the same parental cell line, exposed up to 8 cycles of PII-PDT with the long exposure protocol, obtaining the so called RIF-8A cell line. The degree of resistance was also similar (2-log difference in cell kill). When the resistant cells were injected to mice, resistance to in vivo PDT was observed. In addition, resistant cells explanted immediately following in vivo PDT, were also resistant to the treatment. However, the resistance index was lower, suggesting that the direct cytotoxic effects of PDT on the tumor cells are not sufficient to cause the PDT response, and supports the role of host-related factors such as damage to microvasculature [12]. Again using the same RIF-1 cells as the parental cell line, Mayhew et al. [4] isolated two strains resistant to polyhematoporphyrin (PHP) and to zinc (II) pyridinium-substituted phthalocyanine (ZnPCP), and demonstrated a 5.7- and 7.1-fold increase in resistance, respectively.

It has been demonstrated that the cause of resistance is highly dependant on the cell origin and the PS employed. However, it was not possible to identify any cellular characteristics that can be predictive of their ability to generate resistant PDT variants. The structure of the PS is believed to be a key point in the development of resistance, and this feature is probably related to its particular subcellular localization. The hydrophobic drug PII localize in plasma membrane or in intracellular membranes including mitochondria, depending on the incubation time [13] whereas the hydrophilic aluminium disulphonated phthalocyanine 
(AlPCS4) and Nile blue A are mainly located in lysosomes [14, 15]. Singh et al. [16] employed these 3 PS with different intracellular localization to induce PDT-resistant variants (Fig. 1). They found various degrees of resistance, and only from the colon adenocarcinoma HT29 line it was possible to generate resistant variants employing the three PS. From the bladder cell HT1376 line, only resistance to Nile blue A was achieved, whereas the SK-N-MC neuroblastoma did not develop any resistance at all. Thereafter, induced resistance appears to be towards the drug itself and not necessarily toward photosensitization.

We have demonstrated [7] that it was possible to isolate cells resistant to PDT employing a precursor of a PS. In recent years, 5-aminolevulinic acid (ALA)-mediated PDT has become one of the most promising fields in PDT. ALA is the pro-drug of the PS Protoporphyrin IX (PpIX). After ALA administration, cells generate PpIX through the haem biosynthetic pathway. ALA induces PpIX accumulation preferentially in certain tumor cells, primarily due to the reduced activity of ferrochelatase, the enzyme responsible for the conversion of PpIX into heme [16] and a relative enhancement of deaminase activity, the enzyme responsible for the passage of ALA to Uroporphyrin [17].

We developed two clones resistant to ALA-PDT from a murine mammary adenocarcinoma cell line. The clones exhibited 6.7 and 4.2 -fold increase in resistance, respectively. On the contrary, no evidence of PDT resistance was found in response of human glioma spheroids to repetitive ALA-PDT [18], showing again that resistance to PDT comprises a broad number of aspects and not all the cell types and cell models develop resistance to the same PS.

It is important to study the mechanisms of PDT resistance because this information can be used to improve combinations of treatments such as PDT plus chemotherapy or radiotherapy. It is also relevant to further elucidate the mechanisms of action of PDT, and to study the relationship between PDT cytotoxicity and cellular changes. In addition, comparison of the photosensitivity of tumors grown in vivo from cells with different PDT sensitivities induced in vitro, may also help to elucidate the role of the vasculature in PDTinduced damage [12]. Developing methods to measure PDT dosimetry, and establishing the number of PDT cycles required for optimal treatment and the cellular mechanisms modified by PDT are all necessary in lieu of an increase in the PDT applications [19-22]. In this review we will classify the different features observed in relation to PDT resistance, leading to a comparison with the mechanisms most commonly found in chemoresistant cells.

\section{PHOTOSENSITIZER ACCUMULATION}

\subsection{Photosensitizer Subcellular Distribution. The Role of Mitochondria}

RIF-1 PII-PDT-resistant clones isolated by Luna \& Gomer [6] accumulated a slightly increased amount of PS per cell, but on the other hand, a slightly lower amount of PII on a per $\mathrm{mg}$ protein basis. However, a decreased expression and function of alpha- 2 macroglobulin receptor/low density lipoprotein receptor, involved in the transport of PII, suggested that the modulation of PII uptake and/or subcellular localization occurs in PDT resistant cells [23].

The PII-PDT resistant clones isolated by Singh et al. [5] displayed also similar amounts of porphyrin fluorescence per unit cell volume compared with the parental lines. They performed colocalization studies employing Rhodamine 123 and ION-nonyl acridine orange (NAO). Rhodamine 123 accumulates in the mitochondrial matrix and is a good indicator of mitochondrial membrane function [24]. NAO binds to cardiolipins in the inner mitochondrial membrane and is an indicator of mitochondrial number density [25]. These 
studies reflected that at long time exposure to the PS, Rhodamine 123 and PII have a weaker colocalization in the resistant variants. In addition, PII competence with NAO was more marked in the resistant lines, suggesting that the inner mitochondrial membrane is a significant PII binding site and may be related to the mechanism of resistance [26].

In our laboratory [7] we found that the amount of porphyrins synthesized per cell in the resistant clones to ALA-PDT was similar to the parental cell line, but when it was expressed per mg protein, there was a 2 -fold decrease. This means that less porphyrins are available to target the same amount of proteins and, as it has already been demonstrated; proteins are a target for PDT [27]. If the amount of porphyrins and not the target molecule is the limiting factor in photodamage, this feature can lead to development of resistance.

In addition, we reported in the same clones, alterations in the enzymes of the haem pathway that produces PpIX, with a higher proportion of hydrophilic porphyrins (Table 1, Fig. 2). It has been shown that hydrophilic porphyrins such as coproporphyrin, and uroporphyrin are poor photosensitizers $[28,29]$, and this feature was found to be related to its membrane partitioning behavior and consequently, with lower cell uptake [30]. In addition, different subcellular localization of these hydrophilic porphyrins may also contribute to the resistance.

We have also found an increased number of mitochondria per cell, which is particularly important in the case of ALA-PDT, since the last steps of ALA conversion into PpIX take place in mitochondria [7]. There is little doubt that mitochondria are critical targets in the actions of PDT. PS, in particular porphyrins, significantly damage mitochondria [31, 32] causing inactivation of numerous mitochondrial enzymes, inhibition of adenosine triphosphatase and uncoupling of oxidative phosphorylation [33, 34]. Moreover, as it will be discussed, PS localized in mitocondria are able to induce apoptosis very rapidly [35, 36].

Several mitochondrial alterations have been reported in cells exposed to various selective pressures, including antineoplasic treatments [37-39]. The downregulation of mitochondrial RNA may represent a general mechanism by which cells protect themselves against oxidative stress. At least 7 of the $15 \mathrm{mRNA}$ and rRNA encoding gene products in mitochondria are down-regulated by oxidative stress, probably representing an early stage "shut down" of mitochondria [40]. Shen et al. [41] used messenger RNA differential display to identify genes that were differentially expressed, and they found a reduction of mitochondrial 16S rRNA and NADH dehydrogenase subunit 4 in the PDT-resistant variants of HT29 human colon adenocarcinoma.

Singh et al. [42] assessed the response to mesoporphyrin-PDT of a cell line lacking mitochondrial DNA, and they found that this line was extremely resistant to PDT as well as Doxorrubicin (DXR) treatment, but not to alkylating agents or $\gamma$-irradiation. Although mitochondria have been extensively involved in the apoptotic cell death [43], the resistance was not due to changes in apoptosis. DXR activation in mitochondria requires reduction to semiquinone free radicals by Complex I in mitochondria, and then it is reoxidized to reactive oxygen species. These studies indicate that free radicals produced by mitochondria must play a critical role in cell death induced by both DXR and PDT.

Changes in mitochondria of the RIF clones resistant to PII-PDT were described by Sharkey et al. [44]. The study showed that the mitochondria of the resistant RIF-8A cells were smaller, more electron dense and higher in cristae density than the parental RIF-1 cell line. The total mitochondria area per cell in the resistant line was double that of the parental line. In addition, the ATP content and succinate dehydrogenase activity of the resistant cells were higher and oxygen consumption rates were similar to the parental cell line. That is, for an equivalent rate of oxygen consumption, resistant cells contain a greater intracellular ATP 
pool, suggesting an altered energy metabolism. On the other hand, the RIF-8A resistant cell line accumulated less Rhodamine 123, suggesting a decrease in mitochondrial potential.

We found [7] that ALA-PDT resistant clones displayed higher protein content and increased number of mitochondria, together with a higher oxygen consumption. However, when normalized per protein content, the number of mitochondria was similar for both cell lines. It is also noteworthy that although the number of mitochondria is higher in the resistant cells, PpIX synthesis which takes places in mitochondria, is not increased

\subsection{Multidrug Resistance and P-Glycoprotein}

Multidrug resistance (MDR) is the major confounding factor in solid tumour chemotherapy $[45,46]$. MDR is a complex phenomenon that may be caused simultaneously by several mechanisms functioning in one and the same cell. Although various mechanisms involved in MDR can be identified, it remains a major problem in oncology. These mechanisms include: (i) the enhanced activity of drug pumps, i.e. ABC or alternative transporters, (ii) modulation of cellular death pathways, (iii) alteration and repair of target molecules, and (iv) other less common mechanisms. Together they build a complex network of cellular pathways and molecular mechanisms mediating an individual MDR phenotype [47].

P-glycoprotein (P-gp), also called ABCB1 is coded by the MDR1 gene, and it is one of the ATP-binding cassette $(\mathrm{ABC})$ drug transporters held responsible for the phenomenon of multidrug resistance acting as drug efflux pump for antineoplastics with broad substrate specificity.

No overexpression of P-gp was found in cell lines obtained from multiple PDT treatments. The RIF-1 PDT-resistant cells isolated by Luna \& Gomer [6] did not exhibit a MDR phenotype, by means of mRNA analysis of P-glycoprotein. In line with these findings, the PII-PDT resistant variant RIF-8A isolated by Singh et al. [5] from the same parental cell line, showed (i) similar uptake of DXR, (ii) no cross-resistance, and (iii) similar amounts of P-gp expression. However, the same RIF-8A cells were cross-resistant to cisplatin treatment [48].

In addition, the reverse situation is also variable, since many but not all MDR resistant cell lines have been shown to be resistant to PDT. Singh et al. [5] showed that the Chinese ovary hamster CHO-MDR line derived from multiple chemotherapy treatments, showed crossresistance upon exposure to PII-PDT, and this was correlated with a lower PII accumulation. Similarly, Kessel et al. [49], employed copper benzochlorin iminium salt, a cationic PS, and demonstrated cross-resistance to PDT in P388/ADR murine leukemia cells resistant to DXR, because of impaired cellular accumulation of the PS due to P-gp efflux pump activity.

On the other hand, Kessel and Erickson [50] have shown that the same murine leukemia P388/ADR cells were not cross-resistant to mesoporphyrin-PDT, demonstrating the dependence of the PS structure on the affinity for the P-gp.

MCF-7 TX200 mammary carcinoma cells overexpressing multidrug resistant associated protein 1 (MRP1) or P-gp showed equal intracellular accumulation of chlorins, porphyrinbased PS and pheophorbides compared to the MCF-7 control cells [51]. Moreover, MCF-7/ DXR cells (DXR resistant variant) were more sensitive to meta-tetra(hydroxyphenyl)chlorin (m-THPC)-PDT than its parental cells [52].

Robey et al. [51] suggested that the pro-PS ALA is not a P-gp substrate. They observed a negligible increase in intracellular ALA levels upon incubation of MCF-7 TX200 transfected cells with a P-gp inhibitor. Li et al. [53] also observed similar PpIX levels in 
MDR resistant leukemia cells exposed to ALA, and only small differences upon incubation with and without the P-gp inhibitor verapamil.

On the other hand, employing ALA derivatives, Chu et al. [54] showed that P-gp has certain affinity for either hexyl-ALA or PpIX. Human uterine sarcoma cells MES-SA-Dx5 overexpressing P-gp, showed reduced intracellular levels of PpIX derived from hexyl-ALA but to a limited degree, and this mechanism could be reversed by using P-gp inhibitor verapamil. P-gp expression was also related to a slight reduction in hexyl-ALA photosensitivity.

There are also some interesting but still unexplained findings about the relationship between MDR cell phenotype and PDT response. Tsai et al. [55] found that MCF-7/DXR cells accumulated a lower level of PpIX from ALA, as compared to the parental MCF-7. However, ALA-PDT was still less effective for MCF-7/DXR cells than MCF-7 cells even with similar amounts of PpIX, indicating that the resistant cells might possess intrinsic mechanisms that render them less sensitive to ALA-PDT and is not related to MDR efflux of PpIX.

Another unexpected but significant finding was that hexyl-ALA-PDT induced a drug and light dependant decrease in MDR1 mRNA levels in uterine fibrosarcoma MES-SA-Dx5 cells (resistant to DXR) together with a concomitant decreased expression of P-gp [54]. Similarly, Pheophorbide-PDT of multidrug resistant HepG2 cells induced c-Jun N-terminal Kinase activation, leading to a down-regulation of P-gp [56].

The influence of PS distribution on the MDR phenotype of P-gp overexpressing cells was reported in the last few years. Selbo et al. [57] showed that MES-SA-Dx5 cells were more resistant to PDT with disulfonated meso-tetraphenylporphine (TPPS2a). The process was not mediated by P-gp classical mechanism, as there were no differences in the uptake and efflux of TPPS2a as compared with the parental cell line. The authors suggested possible differences in endocytic vesicle localization of TPPS2a, speculating that the lysosomal targeting by PDT induces a stronger cytotoxic effect than PDT of endosomes. According to later investigations of Chu et al. [54] and Tang et al. [56], this finding may be related to an indirect downregulation of MDR, or alternatively, one of the MDR-associated mechanisms different from drug efflux.

Merlin et al. [58] found that neither Chlorin e6 accumulation nor efflux was different in MCF-7 and MCF-7/DXR overexpressing P-gp, but its subcellular distribution was different between both the cell lines. The presence of P-gp inhibitor restored the distribution of the PS and was found to potentiate the Chlorin e6-PDT to a similar extent in both cell lines.

Based on the information available, it appears that MDR confers a degree of PDT resistance in certain cases, and this resistance is strongly dependant on the structure of the PS and its affinity for the P-gp. However, there are no rules for cross resistance, and dependence on the cell type and PS type are important factors, as well as intracellular distribution of the PS.

1.2.1 Reversal of MDR Phenotype by PDT Treatments-Regarding vasculartargeted PDT, Preise et al. [59] have shown that P-gp-expressing human HT29/MDR colon carcinoma cells in culture were resistant to PDT with palladium-bacteriopheophorbide WST09 (TOOKAD). TOOKAD is a chemical entity of a new generation of hydrosoluble PS, with high binding to albumin and pure focal intravascular effect (Fig. 3). In contrast to the rest of PS, the molecule does not extravasate and remains constrained in the circulation. However, TOOKAD-PDT induces tumor necrosis with equal efficacy in HT29/MDR- 
derived xenografts and their wild type counterparts, demonstrating that the vascular-targeted PDT bypasses drug resistance.

In addition, photochemical internalisation (PCI) was reported to overcome chemoresistance in several MDR cell lines employing different PS and therapeutic drugs [57, 60, 61]. PCI involves localization of PS together with the drug of choice in endocytic vesicles within target cells, where the PS is specifically localized to the vesicular membrane [62]. Endocytosed macromolecules and PS are exposed to light, causing an efficient delivery of the drugs into the cytosol.

Lou et al. [60] showed that MCF-7 and MCF-7/ADR cells were equally sensitive to PCI with TPPS2a. In MCF-7/ADR cells preloaded with DXR, the drug was released into the cytosol after PCI treatment and entered cell nuclei, as was seen in MCF-7 cells without PCI, thus reversing the MDR phenotype by endo-lysosomal release of the drug. On the other hand, no PCI-induced increase in DOX sensitivity could be observed in MES-SA and MESSA-Dx5 cells employing TPPS2a as a PS [57].

Adigbli et al. [61] employed PCI and co-administration of hypericin with mitoxantrone without alterations in P-gp expression, and were able to overcome the resistance of bladder MGHU-1 and breast cancer MCF-7 cells and their P-gp-overexpressing MDR subclones.

Selbo et al. [57] also evaluated the reversal of resistance induced by PCI of macromolecules that are not the target of $\mathrm{ABC}$ drug pumps such as the plant toxin gelonin and adenovirus. MES-SA and MES-SA-Dx5 cells were equally sensitive to PCI of gelonin (ribosomeinactivating protein) even though the endocytosis rates were lower in the MDR cells. The two cell lines are equally sensitive to PCI of gelonin at the lower light doses. At higher light doses the MES-SA/Dx5 cells are more sensitive to PCI of gelonin than the MES-SA cells. After adenoviral infection, PCI enhanced the fraction of transduced cells substantially, in both cell lines, suggesting the potential use of PCI of macromolecular therapeutic agents that are not targets of P-gp as a strategy to kill MDR cancer cells.

\subsection{ABCG2-Mediated Transport of Photosensitizers}

In addition to P-gp, another $\mathrm{ABC}$ transporter capable of causing cancer drug resistance has been described. Overexpression of a novel member of the G subfamily of $\mathrm{ABC}$ transporters was described in the cell line MCF-7/AdrVp. The new transporter was termed the breast cancer resistance protein (BCRP), and was formally designated as ABCG2 [63, 64]. Like all members of the ABCG subfamily, ABCG2 is a half transporter. The spectrum of anticancer drugs effluxed by ABCG2 includes mitoxantrone, camptothecin-derived and indolocarbazole topoisomerase I inhibitors, methotrexate, flavopiridol, and quinazoline ErbB1 inhibitors [65]. ABCG2 is believed to function as a component of the organism's defence against toxicity by restricting the entry of genotoxins from the intestinal tract into the organism and by facilitating the removal of toxic metabolites from the organism via bile or urine [66].

Studies with an ABCG2 knockout mouse have provided evidence for the ability of the transporter to efflux PpIX and protect cells from phototoxicity [67]. Tsunoda et al. [68] have also demonstrated correlation between the expression of ABCG2 and resistance to PII-PDT. Robey et al. [51] hypothesised that it may be involved in resistance to PDT. Based on their finding that the PS Pheophorbide a, is an ABCG2 substrate [69], they explored its ability to transport PS with a similar structure. ABCG2-overexpressing NCI-H1650 MX50 bronchoalveolar carcinoma cells were found to have reduced intracellular accumulation of Pyropheophorbide a methyl ester, Chlorin e6 and PpIX from ALA. On the contrary, intracellular accumulation of hematoporphyrin IX, meso-tetra(3-hydroxyphenyl)porphyrin 
(m-THPP), and m-THPC was not altered (Fig. 4). On the other hand, ABCG2-transfected human embryonic kidney HEK-293 cells were resistant to PDT with pheophorbide a, pyropheophorbide a methyl ester, Chlorin e6 and ALA but not to m-THPC. These studies suggest that the degree of $\mathrm{ABCG} 2$ mediated-resistance changes significantly with the PS employed and cell line.

Of great importance in the outcome of PDT, it has been suggested that decreased expression of ABCG2 may be a widespread phenomenon in human cancers. Gupta et al. [70] showed down-regulation of ABCG2 mRNA with malignant change in 12 different tissues in arrays of paired normal and cancer cDNAs. They reported also down-regulation at the mRNA level of $\mathrm{ABCG} 2$ in human specimens of colorectal and cervical cancer.

In addition, tyrosine kinase inhibitors can block the function of ABCG2. Liu et al. [71] tested the effects of these inhibitors on the response of PDT-treated cells. They employed human and mouse cell lines with a range of ABCG2 expression, as well as a control cell line transfected with ABCG2: i) BCC-1 cells from human basal cell carcinoma and RIF-1 fibrosarcoma cells (high expression), ii) Colo 26 colon carcinoma cell (moderate expression) and iii) human head and neck squamous cell carcinoma line $\mathrm{FaDu}$ (no expression). Efflux of 2-(1-hexyloxethyl)-2-devinyl pyropheophorbide-a (HPPH), PpIX from ALA and Benzoporphyrin Derivative monoacid ring A (BPD-MA) was shown in ABCG2+ cells but PII and a novel derivative of HPPH conjugated to galactose were minimally transported (Fig 5). HPPH and PpIX were more effectively transported than BPD-MA, showing a PSdependent variation on the affinity for this transporter. The tyrosine kinase inhibitor Imatinib mesylate increased accumulation of HPPH, PpIX, and BPD-MA in ABCG2+ cells, but not in ABCG2- cells, and enhanced PDT efficacy both in vitro and in vivo in a RIF-1 tumour model, demonstrating that the inhibition of ABCG2 transport may enhance efficacy and selectivity of clinical PDT. The structure of the PS is a keypoint in the resitance mediated ABCG2. In this study, the multimeric molecule Photofrin is not an ABCG2 substrate, and in addition, monomeric agents but carbohydrate conjugation to a pyropheophorbide molecule blocks transport, as do the modifications in porphyrins and chlorins [51].

It still remains under debate as to whether or not Photofrin is a substrate of BCRP. Usuda et al.. [72] showed that human epidermoid carcinoma A431 cells overexpressing ABCG2, were resistant to PII-PDT but not to Mono-L-aspartyl chlorin e6 (NPe6-PDT), which has a similar structure to m-THPC (Fig 4), and the resistance was reversed by Fumitremorgin C, a non tyrosine kinase inhibitor of ABCG2. In accordance, a higher expression of ABCG2 in tumor samples obtained from patients with centrally located early lung cancers was inversely correlated with efficacy of PII-PDT but the correlation was restricted to small lesions.

Jendzelovský et al.. [73] reported for the first time the modulation of $\mathrm{ABC}$ transporters by a PS. They showed an increased activity of MRP1 and ABCG2 in HT-29 colon cancer cells treated with hypericin treatment without light. In addition to baseline ABCG2 expression, hypoxia, which is very common in tumors, has been found to up-regulate expression of ABCG2 and to increase cell survival by decreasing intracellular accumulation of heme and other porphyrins [74]. Therefore, hypoxia may inhibit PDT not only because the photodynamic process requires oxygen, but also through ABCG2-mediated decrease in intracellular photosensitizer levels.

To sum up, similarly to P-gp, resistance to PDT conferred by ABCG2 transporter varies significantly with the cell line and the PS employed, and ABCG2 inhibitors can reverse this PDT resistant phenotype. 


\section{DNA ALTERATIONS AND GENE EXPRESSION}

PDT activates several signaling pathways, which in turn alter the expression of many different downstream genes. After PDT, inhibition of DNA and RNA polymerases and synthesis of DNA, RNA and protein have been demonstrated [41]. Some of the signal transduction pathways triggered by PDT are stress responses aimed at cell protection, while others are likely to contribute to the cell death process. Many PS bind to various cytoplasmic membranes but are not found in the nucleus and do not bind to DNA. Nevertheless, some DNA damage is produced that can lead to mutagenesis, the extent of which is dependent on the PS, the cellular repair properties, and the target gene [75]. Moreover, a number of investigators have shown that DNA damage is induced following PDT [76-79].

\subsection{DNA Repair and Karyotype}

Cell variants resistant to PII-PDT derived from the radiation-induced murine RIF cells [5] are cross resistant to UV light. And the LY-R murine leukaemia cell line, which is deficient in the repair of UV-induced DNA damage, is also cross-sensitive to PDT [78,80]. This suggests some overlap in the type of cellular damage induced by UV and PDT and/or an overlap in the pathways for the repair from damage.

DiProspero et al. [81] employed an assay for adenovirus DNA synthesis as an indicator of recovery from PDT in the RIF-8A cells resistant to PII-PDT. An increased capacity for viral DNA synthesis was observed in the RIF-8A cells compared with the parental cells, suggesting that the increased resistance to PDT resulted from an elevated recovery and/or repair from DNA damage. The capacity of UV-irradiated cells for viral DNA synthesis was also greater for RIF-8A cells, indicating a cross-resistance to UV. While RIF parental cell line shows a mixture of diploid and tetraploid subpopulations, some of the RIF PDTresistant variants have a complete tetraploid phenotype [6], suggesting that DNA damage is somewhat involved in photodamage.

On the other hand, employing the C3H 10T 1/2 mouse embryo cell system, Gomer et al.., [82] found that at the DNA level, PII-PDT does not induce any mutations. In addition, the effect of loss of DNA mismatch repair activity on the sensitivity to m-THPC-PDT was tested employing DNA mismatch repair-deficient cells, and it was found that this feature did not contribute to PDT resistance [83]. This controversy suggests that upon certain conditions, the DNA damage can influence resistance to PDT depending on PDT conditions, the PS employed, and the cell model used.

\subsection{Induction of Early Response Genes and Signal Transduction Pathways}

Activation of the early response genes does not require protein synthesis and is usually of a transient nature. Oxidants such as physical, biological, and chemical stresses including ultraviolet irradiation, growth factors, and tumor promoters induce a family of early response genes $[84,85]$. Protein products of the early response genes act as transcription factors and thereby regulate the expression of a variety of genes via specific regulatory domains. The application of high-resolution microarray platforms to the gene expression after PDT has revealed the involvement of several genes related to survival signals that could be responsible of the development of resistance to PDT. Early-response genes mostly upregulated after PDT-mediated oxidative stress encodes transcription factors such as JUN, FOS, MYC, EGR-1, NF-kB, ERK, JNK and p38MAPK, among others [11, 86-90] (Table 2).

FOS and JUN play a role in cell proliferation, apoptosis, and stress response [91] are generally upregulated by stress and cell damage, and are the most commonly induced early response genes after PDT. The JUN and FOS proteins together form the activator protein-1 
(AP-1), which has a function in apoptosis modulation, cell proliferation, and cell survival. Krammer group studied gene expression after ALA-PDT employing cDNA-array techniques. They found a strong induction of expression of the immediate early genes c-JUN and c-FOS, FOSB and p55-c-FOS after ALA-PDT of the squamous cell carcinoma line A-431 [11, 90, 91]. Similarly, ALA-PDT induced continuous upregulation of c-FOS in one normal urothelial (UROtsa) and two tumor cell lines (RT4, urothelial; HT29, colonic) [92]. Accordingly, Luna et al.. [86] have shown that PII-PDT mediates induction of FOS through protein kinase-mediated signal transduction pathways.

Pheophorbide-PDT of multidrug resistance HepG2 cells induces c-JUN N-terminal Kinase activation leading to activation of intrinsic apoptotic caspases and down-regulation of P-gp [56].

Activation of several cell survival signal transduction pathways including protein kinase $\mathrm{C}$ (PKC) [92], Etk/Bmx tyrosine kinase [94], protein kinase B (PKB/Akt) [95, 96], mitogenactivated protein kinases (MAPK) [97], Phosphatidylinositol 3-kinase (PI3K) [96, 97], and extracellular signal regulated kinases (ERKs) [98] have also been reported after PDT treatment.

CDNA arrays were also used as a tool to discover several signal transduction pathways induced by PDT treatment. Hypericin-PDT was found to induce in the human squamous cell carcinoma cell line A-431 several genes involved in various metabolic processes, stressinduced cell death, autophagy, proliferation, inflammation and carcinogenesis thus pinpointing the coordinated induction of a cluster of genes involved in the unfolded protein response pathway after endoplasmic reticulum stress and in antioxidant response [90].

Mitogen-activated protein kinases (MAPK) signal transduction pathways are involved in the regulation of numerous physiological processes during development and in response to stress. Analysis of PDT-treated cells after p38MAPK inhibition or silencing unraveled that the induction of an important subset of differentially expressed genes regulating growth and invasion, as well as adaptive mechanisms against oxidative stress, is governed by this stressactivated kinase. P38 MAPKs are members of the MAPK family, and p38MAPK inhibition blocked autonomous regrowth and migration of cancer cells escaping PDT-induced cell death [99].

Sanovic et al. [90] found that the most highly upregulated gene following hypericin- PDT of A-431 cells model is DUSP1, the dual specificity phosphatase 1. DUSP1 is an early immediate gene acting as inactivator of MAPK, and it is overexpressed after oxidative/heat stress and growth factors [100]. Upregulation after PDT reached a maximum of 243-fold which is very likely to be induced by oxidative stress. Being a negative regulator of ERK, JNK or p38MAPK, DUSP1 is presumably the main switch for inactivating all these pathways, especially proliferation signaling, and inducing apoptosis [90]. DUSP1, was both up-regulated in normal and tumor cells after ALA-PDT [92].

Following exposure to stress agents, various degrees of histone $\mathrm{H} 3$ modification at the DUSP1 chromatin may occur and it has been suggested that chromatin remodelling after stress contributes to the transcriptional induction of DUSP1 [101]. A concomitant upregulation of $\mathrm{H} 3 \mathrm{~b}$ was also found in Hypericin-PDT treated cells, thus suggesting that DUSP1 is possibly activated via $\mathrm{H} 3$ histone modifications [90]. Similar results were found by Buytaert et al. [99] with an upregulation of the genes encoding for histones $\mathrm{H} 2 \mathrm{~A}$ and H2B after hypericin-PDT. 
ETR101 is another immediate early gene involved in cellular stress response, of which mRNA levels were up-regulated in colonic HT29 cells after ALA-PDT but down-regulated in tumor urotheilal RT4 cells [92], showing some cell line specificity.

The growth and differentiation factor 15 (GDF15) protein is a signal transducion factor in cellular response to injuries and seems to be expressed in an organ-independent manner and after a severe deadly stimulus as a cellular response and in attempt to survive. GDF15 gene was found to be regulated following ALA-PDT. The normal urothelial cell line UROtsa with apoptotic behavior following photodynamic therapy showed no regulation of this gene. On the other hand, RT4 tumor urothelial as well as HT29 tumor colon cells with a clear necrotic response to photodynamic therapy showed a strong activation of GDF15 RNA expression levels [92].

Ras proteins comprise a group of small GTP-binding proteins with essential roles in controlling the activity of crucial signaling pathways regulating normal cellular proliferation [102]. Mutations at the hot-spots in Ras proteins lead to defects in GTPase activity and constitutive activation of downstream signals. Ras proteins are constitutively activated in around 20 to $30 \%$ of human tumors, indicating the importance of this signaling pathway during carcinogenesis. Indeed, constitutive activation of Ras protein contributes significantly to several aspects of the malignant phenotype, including the alteration of tumor-cell growth and invasiveness [102, 103]. In this sense, it has been described that overexpression of Ras proteins are also involved in the resistance to cell death [104, 105].

We have found that Ras oncogene confers resistance to ALA-PDT [106] as well as PDT with other PS such as PII, merocyanine 540 (MC540), BPD-MA, acridine orange and mTHPC [107] (Fig. 6). In the mammary Ras transfected cells employed, PII, BPD-MA and mTHPC mainly localizes in mainly mitochondria and endoplasmatic reticulum. On the other hand, acridine orange exhibits a lysosomal pattern and MC540 is localized in plasma membrane, Golgi, mitochondria and reticulum. In this case, PS of very different structure and subcellular localization, are equally resistant to photodynamic treatment, showing that Ras oncogene induced resistance, appears to be toward PDT and not toward a particular PS.

It has also been shown that oncogenic activation of H-Ras as well as PI3K in murine keratinocytes can prevent cell death induced by immunological disruption of E-cadherin adhesion [96]. In addition, Zn-phthalocyanine (Zn-PC)-PDT photodamage is bypassed in cells showing constitutive activation of H-Ras and PI3K concomitant with the expression of phosphorylated Akt (Fig 6).

\section{APOPTOSIS, AUTOPHAGY AND SIGNAL TRANSDUCTION PATHWAYS ASSOCIATED WITH PROGRAMMED CELL DEATH. THE ROLE OF PS SUBCELLULAR LOCALIZATION}

The induction of apoptosis by most physiological stimuli or toxic agents, proceeds through a series of signaling pathways, and PDT, as it has been previously addressed, has been found to upregulate numerous signaling pathways. Some of these signals act as mediators or promoters of apoptosis in PDT-treated cells, and some are stress responses whose function is to promote repair or tolerance of damage [108], which can be related to the appearance of resistance.

Several indirect evidences indicate that the complex machinery of apoptosis is directly related to induction of resistance particularly in models of gene transfections. However, a few studies have demonstrated direct evidence of altered apoptosis pathways in cells rendered resistant to PDT by multiple treatments. 
The initial step in the photodynamic process involves localization of the photosensitizing agent at subcellular loci. These can be highly specific or quite broad, and have been reported to include the endoplasmic reticulum (ER), mitochondria, Golgi, lysosomes (Fig 7) and plasma membrane (Fig 8). Most PS are relatively hydrophobic and will be attracted to membranes. There are some exceptions to this rule, e.g., the sulfonated porphyrins/ phthalocyanines and NPe6. Even these molecules, although having substituents that render them watersoluble, bind to membranes because of their hydrophobic ring systems [109]. Kessel group have extensively studied subcellular localization of PS and its relationship with the type of cell death [36].

Depending on localization of the photosensitizing agent, the process can induce photodamage to the endoplasmic reticulum, mitochondria, plasma membrane, and/or lysosomes. When ER or mitochondria are targeted, antiapoptotic proteins of the $\mathrm{Bcl}-2$ family are especially sensitive to photodamage. However, targeting of the plasma membrane by a PS may lead to either a marked delay or inhibition of apoptosis and rescue responses are initiated, even if other sub-cellular sites such as antiapoptotic proteins are also targeted for photodamage $[35,110]$ (Fig 7).

The same group [111] evaluated the PDT responses to two structurally related photosensitizing agents, using P388 murine leukemia cells. Photodamage mediated by tin etiopurpurin (SnET2) involved lysosomes and mitochondria and yielded a rapid apoptotic response within $1 \mathrm{~h}$ after PDT. A drug analog, tin octaethylpurpurin amidine (SnOPA), targeted lysosomes, mitochondria and cell membranes; apoptotic nuclei were not observed until $24 \mathrm{~h}$ after PDT. These results suggest that membrane photodamage can delay or prevent an apoptotic response to PDT thus resulting in resistance to PDT. Similarly, Dellinger et al. [112] reported that cells exposed briefly to a high concentration of Photofrin, then irradiated, exhibited an aborted form of apoptosis and attributed this to leakage of cytoplasmic material through photodamaged membranes.

To provide an explanation for the ability of SnOPA and a monocationic porphyrin (MCP) (Fig 8) to delay or inhibit the apoptotic response to mitochondrial or lysosomal photodamage, Kessel group tested the hypothesis that this might derive from relocalization of PS during irradiation, resulting in photoinactivation of enzymes required for the apoptotic process [110] They provided evidence that relocalization to the cytosol occurs during irradiation.

Fluorescence localization studies on three sensitizers: SnET2, 9-capronyloxy-tetrakis (methyoxyethyl) porphycene (CPO) and m-THPC which had initially been classified as targeting mitochondria, revealed that these agents bind to a variety of intracellular membranes [113]. The apoptotic response to these PS is derived from selective photodamage to the antiapoptotic protein $\mathrm{Bcl}-2$ while leaving the proapoptotic protein bax unaffected. Both CPO and m-THPC induced rapid apoptotic response whereas SnET2 was also associated with lysosomal photodamage eliciting a delayed apoptotic response.

A different localization pattern was observed using two dicationic porphyrins bearing positively charged $-\mathrm{N}(\mathrm{CH} 3) 3$ groups on adjacent or opposite phenyl groups attached to the bridging carbons of a porphyrin structure. The compound were 5,10-di[4-(Ntrimethylaminophenyl)-15,20-diphenylporphyrin (DADP-a) and 5,15-di[4-(Ntrimethylaminophenyl)-10,20-diphenylporphyrin (DADP-o) respectively (Fig 7) [114]. DADP-a is an amphyphillic structure that can penetrate the plasma membrane and selectively binds to mitochondria. The DADP-o structure has a different charge distribution, resulting in lysosomal affinity. DADP-a- PDT resulted in a rapid loss of the mitochondrial membrane potential, usually a prelude to apoptotic cell death. In contrast, DADP-o-PDT 
induced extensive lysosomal photodamage, being the first pathway more efficacious than the latter.

NPe6 (Fig 7) is an amphiphilic PS that bind to endosomal/lysosomal membranes. Upon exposure to light, such membranes will be damaged and become leaky before significant inactivation of lysosomal enzymes can occur. PDT employing NPe6 induces apoptotic response to lysosomal photodamage reflecting an indirect effect mediated by the apoptotic lysosomal pathway involving release of cathepsin B and cleavage of Bid to a truncated form. The latter product can interact with mitochondria resulting in release of cytochrome c, following activation of casapses -3 and -9 . This could result in apoptotic response if release of lysosomal enzymes causes sufficient mitochondrial degradation to facilitate release of cytochrome $\mathrm{c}$ into the cytosol, triggering the apoptotic program [115].

Both apoptosis and autophagy can occur after PDT, autophagy being associated with enhanced survival at low levels of photodamage to some cells [116], serving as a prosurvival response via the recycling of damaged organelles. Autophagy offers protection from the phototoxic effects of low-dose PDT, but can serve as an alternate death mode when the PDT dose is increased [117, 118].

\subsection{Activation of Caspases}

According to Almeida et al. [119], who have reviewed intracellular signaling mechanisms in PDT, two major apoptotic pathways have been characterized, the death receptor mediated and the mitochondria-mediated. In both pathways, the activation of initiator caspases (caspase- 8 or caspase 9) leads to the activation of effector caspases (caspase 3, caspase 6, and caspase 7). In addition, the lysosomal pathway is a prelude for the mitochondriamediated apoptosis after lysosomal photodamage [115].

As addressed above, monocationic PS such as MCP were initially localized in the plasma membrane, and during the first minutes of irradiation, porphyrins migrated to the cytosol [110]. If irradiation continues, photodamage to procaspases -3 and -9 occurs, thereby preventing an apoptotic response. These results may not necessarily be applicable to any PS that initially binds to the plasma membrane, but indicate that the absence of an apoptotic response can result from photodamage to critical elements of the apoptotic program.

Wild et al. [92] studied RNA expression and protein profiling of a normal cell line (UROtsa, urothelial) and two tumor cell lines (RT4, urothelial; HT29, colonic) following ALA-PDT. Whereas RNA expression of CASP8 was unchanged in the 3 cell lines, a delayed activation of caspase- 8 protein was only found in UROtsa cells, whereas no changes were seen in both tumor cell lines, leading to the conclusion that activation of the casapase 8 pathway may serve as a secondary way for the cell to ensure demise in case of damage. Accordingly, Granville et al. [120], found an activation of caspase 8 in HeLa cells treated with BPD-MAPDT, although they have also found activation of caspases 3, 6 and 7 after PDT.

Ruhdorfer et al. [11] studied the alteration of the gene expression pattern in the squamous cell carcinoma A-431 after ALA-PDT by cDNA-array technique, and found that the product of the 'Fas-associated via death domain' (FADD) gene was strongly induced. FADD is as an adaptor molecule which interacts with different cell surface molecules and transmits apoptotic signals to the cell. The receiver is procaspase-8, which in the death-inducing signaling complex is activated to caspase- 8 , leading to the execution of apoptotic cell death.

\subsection{Expression of Apoptotic and Antiapoptotic Proteins}

The Bcl-2 family of proteins acts at a central decision point in the apoptotic pathway. The family is divided into two functional groups: i) antiapoptotic members: Bcl-2, Bcl-XL and 
CED-9 and ii) proapoptotic members including Bax, Bak, BNIP3, as well as the BH3-only subfamily (Bik, Blk, Hrk, BimL, Bad, Bid) [121, 122] (Table 3).

Activation of antiapoptotic Bcl-2 proteins have been early observed after PDT-treatment $[123,124]$, thus being a mechanism supposed to be altered in PDT resistant cells. As explained above, when the mitochondria and/or the endoplasmic reticulum are targeted by photodynamic therapy, photodamage to the anti-apoptotic protein Bcl-2 is observed. On the other hand, lysosomal photodamage ultimately results in activation of the pro-apoptotic protein Bid, also leading to apoptosis [36].

Shen et al. [41] examined the expression of apoptosis-regulating genes in PDT resistant cells. They found an increased expression of Bcl-2, and heat shock protein 27 (HSP27) together with downregulation of Bax in the HT29 cell PDT-resistant variants. On the other hand, they found an increased expression of the proapoptotic BNIP3 by the use of mRNA differential display, and confirmed by Northern blotting and Western blotting. In addition, the mutant of the tumor suppressor protein, p53 was reduced substantially in the PDTresistant variants. The same group reported that PDT-resistant HT29 cell lines showed a significant increase in cisplatin sensitivity concomitant with an increase in both spontaneous and cisplatin-induced apoptosis. Cisplatin sensitivity of the PDT-resistant HT29 variants was also correlated with increased BNIP3 and decreased mutant p53 protein levels, but not HSP27 protein levels [125].

The relevance of the involvement of $\mathrm{Bcl}-2$ was supported by the fact that $\mathrm{CHO}$ cells transfected with the antiapoptotic protein were two times more resistant to PDT [126, 127]. Granville et al. [123] subsequently confirmed the ability of overexpressed Bcl-2 to suppress apoptosis in HL60 cells treated with BPD-MA-PDT. This group also found that overexpressed Bcl-2 or Bcl-xL did not prevent the release of cytochrome $\mathrm{c}$ from mitochondria but instead blocked the activation of several caspases [120]. In addition, human gastric adenocarcinoma MGC803 cells transfected with the antisense Bcl-2 sequence in a retrovirus vector followed by treatment with hypocrellin-PDT rendered more sensitive to PDT [128]. Antisense Bcl-2 also sensitized A-431 cells to Pc 4-PDT [124].

However, the usefulness of Bcl-2 expression as a predictor of PDT response is controversial. Kawaguchi et al. [129] showed no correlation between expression of Bcl-2 or p53 and local recurrence after PDT in a series of biopsies of squamous cell carcinomas of the bronchus previous to treatment with PII-PDT. The levels of Bcl-2 have also been measured in biopsies of esophageal tumors treated with PII-PDT, but again no apparent correlation was found [130]. On the contrary, a screening of biopsies from patients with esophageal cancer treated with PDT suggested that Bcl-2 expression is associated with favorable response to PDT [131]. This finding can be explained by experimental studies showing that PDT induces selective degradation of the Bcl-2 protein, leading to apoptosis by decreasing the $\mathrm{Bcl}-2 / \mathrm{Bax}$ ratio. On the other hand, no association of p53 with response to PDT was noticed.

Xue et al. [132] found that photodamage to Bcl-2 could be induced by Pc 4-PDT in several different cell lines, including human tumor lines. Usuda et al. [133] found that PDT with the same PS, sensitized breast cancer MCF-7c3 cells through Bcl-2 damage. Human breast cancer MCF-7c3 cells expressing stably transfected procaspase-3 were chosen based on its efficient induction of apoptosis in response to Pc 4-PDT. MCF-7c3 cells were transfected with wild-type Bcl-2 or certain deletion mutants lacking one of the membrane anchorage regions (each of which can be photodamaged) which resulted in relative resistance to Pc 4PDT. This indicates that the deleted regions, which include a caspase- 3 cleavage site, are not necessary for the inhibition of PDT-induced apoptosis. In contrast, Bcl-2 mutants, lacking the C-terminal transmembrane domain and do not bind to membrane which is not 
photodamaged, afforded no protection. These results indicate that the extent of Bcl-2 photodamage may determine the sensitivity of cancer cells to apoptosis and to overall cell killing caused by PDT. Furthermore, overexpression of Bcl-2 also inhibited the activationassociated conformational change of the proapoptotic protein Bax, and higher doses of $\mathrm{Pc} 4$ PDT were required to activate Bax in cells expressing high levels of Bcl-2.

MCF-7c3 cells treated with Bax antisense oligonucleotides resulted in a 50\% inhibition of PDT-induced apoptosis. Similarly, following Pc 4-PDT, apoptosis was completely blocked in Bax-negative human prostate cancer DU-145 cells, and restoration of Bax expression restored apoptosis. However, despite the inhibition of apoptosis, the Bax-negative DU-145 cells were as photosensitive as Bax-replete MCF-7c3 cells, suggesting that for Pc 4-PDT, the commitment to cell death occurs prior to Bax activation [134].

A similar pattern of Bcl-2 photodamage and cell death is found for other PS. Usuda et al. [135] showed that PII-PDT damaged Bcl-2 and induced apoptosis. However, NPe6-PDT did not damage Bcl-2 and showed a delayed apoptosis as compared with PII-PDT. Bcl-2 overexpressing cells were considerably more resistant to NPe6-PDT than parental MCF-7c3 cells, concluding that PII-PDT damages different molecular targets, and that the extent of Bcl-2 photodamage can determine the sensitivity of cancer cells to apoptosis and to overall cell killing caused by PDT using the mitochondrion-targeting photosensitizer PII, but not the PS lysosomal-targeting NPe6. On the other hand, NPe6-PDT can induce lysosome disruption and initiate the intrinsic apoptotic pathway, since the use of small interfering RNA for Bid afforded a significant protection against cell NPe6-PDT in human lung adenocarcinoma cells [136].

Ichinose et al. [137] demonstrated that overexpression of wild-type Bcl-2 conferred also relative resistance of MCF-7 cells to PDT with ATX-s10, a PS which localizes not only to mitochondria but also to lysosomes. Pharmacological inhibition of lysosomal cathepsins B and D, protected MCF-7c3 cells from apoptosis caused by ATX-s10-PDT, showing that photolysosomal damage can initiate apoptotic response and this apoptotic pathway can be regulated by photodamage to $\mathrm{Bcl}-2$ via mitochondrial damage. Caruso et al. [138] reported resistance to NPe6-PDT of Tao variant of 1c1c.7 murine hepatoma cells having lysosomal fragility, revealed as reduced cathepsin B and D activities of endosomes/lysosomes. The onset of apoptosis was delayed, and the magnitude of the apoptotic response was muted in Tao cells exposed to NPe6-PDT.

P53 is a tumor suppressor protein, and also the most frequently mutated gene in human tumors. The increased p53 levelslead to transcription of target genes, cell cycle arrest, or apoptotic cell death depending on the cell type or context [139, 140]. Cells lacking functional p53 fail to undergo these responses, resulting in continued proliferation in the face of genetic damage, subsequent genetic instability, and tumor progression. P53-deficient cancer cells are often less responsive to chemotherapy, which lead to the suspicion that it could be somewhat involved in PDT resistance. However, there are no reports of downregulation of this protein in cells induced resistant to PDT.

Zhang et al. [128] showed that wild-type p53 transfected-HT29 human colorectal carcinoma cells were approximately two times more sensitive to PDT using a hypocrellin as PS. Similarly, human promyelocytic leukemia HL60 cells expressing wild type p53 were more sensitive to cell killing by PDT, with either PII or tin ethyl etiopurpurin I (SnET2), than cells in which the p53 genes were deleted or inactive. All of these cell lines underwent rapid apoptosis in response to PDT [141]. LS513 human colon carcinoma cell line expressing wild-type p53 was also more sensitive to PII-PDT compared to the mutated [142]. In addition, normal fibroblasts were more sensitive to PII-PDT than immortalized fibroblasts 
from a patient with Li-Fraumeni syndrome, in which the only p53 allele was mutated [144]. On the other hand, the introduction of the viral oncoprotein E6 to abrogate p53 function in LS513 and MCF-7 cells did not alter their PDT sensitivity [144].

In spite of the broad evidence of the role of p53 on photodynamic sensitivity, no association of p53 with response to PDT was found in two screenings of biopsies of patients treated with PDT $[129,131]$.

An interesting and unexpected finding was the role of p53 in porphyrin-PDT-mediated cell death by direct interaction with the drug, which leads to its accumulation and induction of p53-dependent cell death both in the dark and upon irradiation [145].

\subsection{Autophagy and the Ubiquitin-Proteasome System}

In mammalian cells, the autophagy-lysosomal system, in addition to the ubiquitinproteasome system, represents one of the proteolytic systems for the clearance of PDTdamaged organelles and irreversibly oxidized cytosolic proteins, which are prone to crosslinking and formation of protein aggregates. Accumulating evidence indicates that PDT can stimulate autophagy with functional consequences varying from cytoprotection to the activation of autophagic cell death. The role of autophagy in PDT has been extensively reviewed by Reinners [109]. The induction of autophagy is a common outcome in PDT protocols. It occurs in a variety of cell types, and is not limited to PS that accumulate in specific organelles. PS that preferentially accumulate in late endosomes/lysosomes (i.e., NPe6), ER (i.e., hypericin, CPO), mitochondria (i.e., mTHPC, BPD-MA), or ER + mitochondria (i.e., Pc 4) all induced autophagy following irradiation.

In cells with defective apoptosis, authophagy it is believed to play a crucial role for cell sensitivity to PDT [146]. Loss of Bcl-2 function could lead to the initiation of autophagy [117]. There may also be an autophagic response to the photodamage of ER and/or mitochondria, in an attempt to recycle injured organelles, supporting the hypothesis that authopahy can serve as a protective mechanism $[117,147]$.

Dewaele et al. [148] attenuated macroautophagy using knockdown of the autophagyassociated protein Atg5 or chemical inhibition with 3-methyladenine. This resulted in reduced clearance of oxidatively damaged proteins and increased apoptosis in the Hypericin -PDT treated cells, thus revealing a cytoprotective role of macroautophagy in PDT. Paradoxically, genetic loss of macroautophagy improved clearance of oxidized proteins and reduced photokilling since up-regulation of chaperone-mediated autophagy (CMA) in Atg5(-/-) cells compensated for macroautophagy loss and increased cellular resistance to PDT.

Hypericin-PDT was also reported to induce a cytoprotective autophagic response in melanoma cells [149]. In addition, Atg7 knockdown of leukemia L1210 cells treated with CPO-PDT were more sensitive to the parental cells [109]. To sum up, stimulation of autophagy in apoptosis-competent cells increases cellular resistance to photokilling in PDT protocols. However, the same may not hold for cells incapable of mounting an apoptotic response. For example, knockdown of Atg7 increases resistance to Pc4-PDT in apoptosisresistant MCF7 cells and Hypericin-PDT treatment of Bax-/-Bak-/- double knockout MEFs develop a much stronger autophagic response than their apoptosis-competent wildtype counterparts [109].

Carbonylation leads to exposure of hydrophobic patches within proteins, resulting in their partial unfolding, which favors their ubiquitination followed by recognition and degradation by proteasomes [150]. The ubiquitin-proteasome system (UPS) has been shown to play an 
important cytoprotective role through degradation of oxidatively modified proteins [150, 151]. Treatment with proteasome inhibitors is also associated with formation of intracellular protein aggregates, increased endoplasmic reticulum stress, and unfolded protein response induction in tumor models [152].

Szokalska et al. [153] observed that PII-PDT leads to carbonylation of cellular proteins and induction of unfolded protein response. Pretreatment of tumor cells with proteasome inhibitors sensitized EMT6, C-26 and HeLa cells to PDT-mediated cytotoxicity. Combination of these inhibitors and PDT led to potentiated antitumor effects, thus envisaging a possible role of the UPS in the resistance to PDT.

\subsection{Lipid-Derived Second Messengers: Ceramide}

De novo ceramide can be associated with apoptotic sensitization after oxidative stress [154], and sphingomyelin synthases (SMS) have been shown to regulate cell growth and apoptosis. It has been demonstrated that de novo sphingolipids are associated with initiation of apoptosis after photodamage with Pc 4 -PDT [155]. The same group [156] have shown that overexpression of SMS1 is accompanied by attenuated ceramide response and apoptotic resistance after Pc 4-PDT and that RNA interference-dependent downregulation of SMS was associated with increased apoptosis after photodamage.

\subsection{Phosphatidylinositol-3 Kinase}

Among the many known signal transduction pathways, PI3K has been shown to promote cell survival and resistance to apoptosis [157]. Human prostate LNCaP cancer cells expressing a dominant-negative epithelial and endothelial derived tyrosine kinase (EtK) (substrate of PI3K) were resistant to Pc 4-PDT, suggesting that the PI3-kinase/Etk pathway is involved in the protection of prostate carcinoma cells from apoptosis in response to PDT.

\subsection{Calcium/Calmodulin-Dependent Kinases}

Apoptosis is highly influenced by calcium as a mediator of signal transduction [158, 159]. In this regard, calcium/calmodulin-dependent kinases (CaM-Ks) rescue cancer cells from reactive oxygen intermediates by inducing the activation of antiapoptotic signaling pathways, such as Akt, ERK, and NF-kappaB in many different cell types. Rodriguez-Mora et al. [160] found that when MCF-7 cells were treated with PDT in the presence of a CaM-K inhibitor a greater level of cell killing was observed. In support of this finding, CaM-K inhibition increases hydrogen peroxide-induced apoptosis in MCF-7 cells through ERK phosphorylation.

\section{CELLULAR ANTIOXIDANT DEFENCE MECHANISMS}

PDT is well known to be antagonized by cellular antioxidant defence mechanisms, such as the glutathione system, superoxide dismutases (SOD), catalase or lipoamide dehydrogenase [161-164].

Human breast cancer MCF-7 cells transfected with the glutathione peroxidase gene were protected from PDT damage [165] due to removal of lipid hydroperoxides in living cells after ${ }^{1} \mathrm{O}_{2}$ exposure. In addition, Dabrowski et al. [163] found that PDT toxicity induced by Hypericin was reduced in human kidney 293 cells over-expressing glutathione S-transferase P1-1. Overexpression of glutathione peroxidase-4 reversed nutrient-sensing protein kinase mTOR down-regulation and blocked macroautophagy progression and apoptosis.

Detoxification by glutathione conjugation has been correlated with drug resistance in cancer [167]. Some correlations on the involvement of glutathione system were found in cells 
resistant to PDT. Luna \& Gomer [6] found a slight increase in the reduced glutathione levels in the RIF PII-PDT resistant cells, without any alterations in either glutathione peroxidase or superoxide dismutase levels. On the other hand, no differences in glutathione levels were found in the RIF-8A resistant variant characterized by Singh group [48]. In our ALA-PDT resistant clones [7] we found that the reduced glutathione content expressed on the basis of cell number increased two-fold. However, when expressed per $\mu \mathrm{g}$ protein no difference was observed among the cell lines. It is difficult to evaluate the impact of GSH due to the different protein content of the resistant lines. However the ratio of GSH: endogenous porphyrins, is higher in the resistant clones, and so is the ability to detoxify cytotoxic species per molecule of sensitizer.

In addition, the expression of the SOD2 isoform was shown to be regulated differently by ALA-PDT based on the cell origin. RNA SOD2 expression was up-regulated in tumor urothelial RT4 cells, not regulated in tumor colonic HT29, and slightly down-regulated in normal urothelial UROtsa cells [92] after ALA-PDT treatment.

\section{HEAT SHOCK PROTEINS}

Transcriptional and translational expression of heat shock proteins (HSPs) are associated with modulating cellular damage induced by various stresses including heat, oxidation, chemical exposure [168] and PDT [9]. HSP27, HSP34, HSP60, HSP70, HSP90, HSP110 $[169,170]$, glucose regulated proteins GRPs (GRP74, GRP78, and GRP100) [171] and HO-1 [172] have also been involved in defending PDT damage. Some of these proteins are presumed to be associated with rescue response of cells after PDT.

Upon PDT treatment, the RIF PII-PDT resistant cells [6] exhibited an increase in HSP70 and HO-1 mRNA, but these changes were not reflected in a higher protein synthesis. The same group has previously found that hyperthermia resistant cells overexpressing HSP70 were not cross resistant to PDT [173].

Verwanger and colleagues [91] photosensitized the human squamous cell carcinoma cells A-431 with ALA-PDT and employed the cDNA array technique to find increased expression of HSP70. They also found increased expression of HO-1 following dark incubation with ALA. The HO-1 expression did not increase further by irradiation. Hence the increased expression of HO-1 was probably caused by the need for heme degradation.

Hanlon et al. [174] found a higher expression of HSP60, which is a chaperone protein mainly found in mitochondria both in PDT resistant variants of colon cancer cells HT29 and in fibrosarcoma PDT resistant RIF-8A cells. In 2002, the same group [175] analyzed the expression of stress proteins in the same HT29 cells resistant to PII-PDT by means of microarray technology. They found an increase in HSP27 mRNA that is known to be part of the signaling pathway leading to apoptosis. Stable transfected cells with HSP27 complementary DNA showed an increased survival to PII-PDT suggesting that this protein plays a role in the resistance to PDT. Shen et al. [41] also found an increased expression of HSP27 mRNA in the HT29 human colon adenocarcinoma PDT-resistant variants.

Several studies have shown that various proteins involved in cellular stress response are induced after PDT treatment [35]; for instance, HSP1 was found to be phosphorylated and consequently activated after Pc 4-PDT of mouse lymphoma L5178Y cells [176].

Induction of HO-1 with hemin or stable transfection of colon adenocarcinoma C-26 cells with a plasmid vector encoding HO-1, increased resistance of tumor cells to PDT-mediated cytotoxicity. On the other hand, zinc (II) protoporphyrin IX, a HO-1 inhibitor, markedly 
augmented PDT-mediated cytotoxicity towards C-26 and human ovarian carcinoma MDAH2774 cells [177].

Cells pretreated with a calcium ionophore to increase overexpression of GRP, developed resistance to PDT within 16-h porphyrin exposure [171]. The study also indicated elevated levels of mRNA encoding, GRP-78, GRP-94 and an increase in GRP protein synthesis in RIF-1 cells exposed to 16-h porphyrin incubation prior to light exposure. However, a short (1h) porphyrin incubation prior to light treatment was associated with only minimal increases in GRP mRNA levels or GRP protein synthesis, indicating that specific targets of oxidative damage (modulated by porphyrin subcellular localization) are correlated with PDT-mediated GRP induction. In addition, a transient elevation of GRP mRNA levels in transplanted mouse mammary carcinomas following PDT was observed in vivo.

\section{MORPHOLOGY, CELL ADHESION, CYTOSKELETON AND METASTASES}

The extracellular matrix (ECM) is composed of collagens, elastin, proteoglycans and noncollagenous glycoproteins such as fibronectin and laminin. The ECM forms a complex, three-dimensional network among the cells of different tissues in an organ-specific manner. ECM is a dynamic structure that interacts with cells and generates signals through feedback loops to control the behavior of cells. Thus, ECM macromolecules are bioactive and modulate cellular events such as adhesion, migration, proliferation, differentiation, and survival [178].

Cell-to-ECM adhesion is regulated by specific cellular adhesion molecules known as integrins. Integrins are alpha-beta heterodimeric adhesion receptors that relay signals bidirectionally across the plasma membrane between the extracellular matrix, cell-surface ligands, cytoskeletal and signaling effectors [179]. The onset of drug-resistance to chemotherapy phenotypes is often associated with altered expression of adhesion and cytoskeletal components $[180,181]$.

Recently, it has become clear that cell-cell and cell-matrix interactions result in cytoskeletal reorganization and the activation of multiple signal transduction pathways that directly influence cell survival, growth and differentiation. Experimental evidence shows that antiapoptotic pathways initiated by cell adhesion are operative in tumor cells and, furthermore, cause resistance to mechanistically distinct cytotoxics. The phenomenon has been called cell adhesion-mediated drug resistance (CAM-DR), and is based on the observation that cells that adhere to ECM components are protected from apoptosis induced by chemotherapeutic agents [182].

Cell adhesion to ECM proteins improves cell survival during radiation therapy. Integrinmediated cell-matrix interactions impact favourably on normal and tumor cell survival after irradiation. Similarly to CAM-DR, this phenomenon is called cell adhesion-mediated radioresistance[183]. Cell size reduction and reduced adhesion to ECM proteins are found to be parameters associated with reversal of radioresistance induced by cells overexpressing integrin-linked kinases [184].

Inhibition of cell adhesion by PDT with BPD-MA was shown in 1997 by Margaron et al. [185]. In addition, it was demonstrated that downregulation of several adhesion molecules such as fibronectin could be the reason for the transient decrease in adhesion of human ovarian OVCAR 3 cancer cells to collagen IV, fibronectin, laminin and vitronectin after Verteporfin photosensitization [186].

The adhesive protein fibronectin and its integrin receptors play an important role in tumor development. Tumor cells are generally less adhesive than normal cells thereby contributing 
to tumor cell detachment and metastasis. Rudhorfer et al. [11] observed a dramatic downregulation of the fibronectin gene after ALA-PDT of the squamous cell carcinoma line A-431. This downregulation may simply characterize the beginning of the rounding up and the detachment process of cells after heavy damage. As a side effect, migration in vitro and metastasis in vivo, respectively, could be facilitated. After PDT of colon carcinoma cell lines with external porphyrin-based PS, a transient decrease in adhesiveness and in adhesion molecules expression was found [187]. According to the authors the decrease in adhesiveness could account for the decreased metastatic potential of PDT-treated cancer cells. However, either increased [188] or decreased [189] impact on metastasic ability of the PDT-surviving cells is likely to occur, and these differences may be ascribed to the different PS, light doses, cell model and even location of the tumor.

It has been described an effect of PDT on either decreasing or increasing adhesion to plastic, ECM and to endothelial cells [186, 190, 191]. PDT using BPD-MA inhibited cell adhesion, with no significant differences between matrices and without altering integrin expression [185]. In addition, PDT reduces invasiveness of smooth muscle cells and reduces fibroblast migration, generating a matrix barrier to invasive vascular cell migration, inhibiting experimental intimal hyperplasia [192]. Although the effects of PDT on the ECM are not well understood, it is clear that PDT induces changes in ECM.

One of the cellular PDT targets is cytoskeleton [193]. Three major eukaryotic cytoskeletal proteins are actin, tubulin and intermediate filaments. Any disturbances in these systems have been related to tumor progression and metastasis [191]. Changes in the cell shape (cell attachment, cytoskeleton) in the course of apoptosis execution promote the formation of apoptotic bodies. The clearance of the bodies is done mainly by cells of the immune system. A special case of apoptosis is 'anoikis, i.e., apoptosis induced by cell detachment of anchorage-dependent cells [195].

Extracellular signals, cell-detachment and cell shaping processes receive or transmit their information via intracellular signaling pathways such as p53MAPK, ERK1/2 or JNK. As cited above, Sanovic et al. [90] found promotion of p38MAPK, ERK, JNK and Ras signaling pathways supporting survival and/or apoptosis after Hypericin-PDT.

Sanovic et al. [90] also found upregulation of NEDD9 (neuronal precursor cell-expressed, developmentally down-regulated 9 (human enhancer of filamentation 1 (HEF1)) belonging to the CAS protein family after PDT. This protein localizes at focal adhesion sites, and its early upregulation could participate in apoptosis induction and execution. The NEDD9 overexpression is likely to activate JNK kinases, induce apoptosis and accelerate transition of 'flat' attached cells to rounded mitotic cells.

Integrins mediate cell adhesion and engage in crosstalk with different growth factor receptors. Phosphorylation of these receptors may occur following the binding of a growth ligand to the receptor and also occur by binding to integrins, without ligand binding. Genes encoding integrin $\beta 1$, integrin 3 and integrin 6 were downregulated after Hypericin-PDT [90]. As a consequence, reduced signal transduction from ECM and impaired cell adhesion in the early phase of damage processing has appeared, all required for cell cycle stop and apoptosis. Similarly, downregulation of integrin 2 and $\beta 3$ precursors after Hypericin-PDT were found in a bladder cancer cell model by Buytaert et al. [99]. Downregulation of thrombospondin-1, which is a ligand for integrin $\beta 1$, was also observed in Hypericin-PDT treated A-431 cells [90]. The downregulation of the thrombospondin-1 precursor was also found after Hypericin-PDT by Buytaert et al. [99]. It has been demonstrated that $\beta 1$ integrins play a role in cell detachment and apoptosis induction triggered by loss of E- 
cadherin following PDT with ZnPc [196], thus reinforcing the hypothesis of a role of integrins downregulation on the promotion of cell detachment and apoptosis.

The upregulation of the Rho family GTPase 3 (RhoE) by Hypericin-PDT is also likely to contribute to the process of cell detachment and the control of rearrangements of the actin cytoskeleton, since it inhibits integrin based focal adhesions and formation of actin stress fibres leading to cell rounding. [90]. Another detachment mechanism affected by PDT is the overexpression of Pleckstrin homology-like domain, family A, member 1 (PHLDA1), which also contributes to significant changes in cell morphology and decreased cell adhesion [90].

We have found that our ALA-PDT resistant cells were less invasive and migrant in vitro. The cells were also less metastatic in vivo compared to the parental LM3 adenocarcinoma cells. In addition, anchorage-dependent adhesion was also impaired in vivo in the resistant clones, evidenced by the lower tumor uptake, latency time and growth rate. However, both of the clones showed higher in vitro binding to the ECM protein collagen I, without overexpression of $\beta 1$ integrin, which is the main molecule involved in collagen I binding [197]. In addition, the resistant clones exhibited also loss of actin stress fibers, as well as disorganized the actin cortical rim. E-cadherin, $\beta$-catenin (cell-cell adhesion proteins) and vinculin (cytoskeleton-associated protein) distribution was also disorganized, without differential expression in Western blot assays [197]. The reorganization of these cytoskeletal and adhesion proteins can probably be correlated with the lower metastatic phenotype.

Vimentin is a major cytoskeletal protein degraded in response to various inducers of apoptosis $[198,199]$. In cells transfected with a caspase-resistant vimentin, apoptosis driven by PDT was partly suppressed and delayed, suggestingthat vimentin confers resistance to PDT by impairing caspase-3 translocation [200].

Plating efficiency of some of the PII-PDT resistant variants was reduced to 36-43\% [6]. When the PII-PDT resistant variant cells were injected in syngenic mice, the number of cells required to produce tumors was 1,000 to 10,000 times higher than nonresistant cells. From our view point, this feature may also be related to changes in the extracellular matrix of the PDT resistant clones. Similarly, we have found an impairment of plating efficiency in our variants resistant to ALA-PDT [189], which was correlated with lower tumor take when injected to mice. In addition, when various cell lines with different histologies were exposed to PII-PDT, a general association was noted between PDT sensitivity and the plating efficiency, but no association was observed on PS uptake [201].

As addressed above, the fact that cellular shape is an important factor in the regulation of cell sensitivity to mitogens, it becomes evident that the proliferative rate is anchorage dependent [202]. The cellular shape is dictated by the extracellular material upon which the cells rest (in vivo condition) and by the substrate upon which the cells are maintained (in vitro condition). The substrate itself may, in turn, induce the cells to manufacture their extracellular material and specific cell surface proteins which control the cellular shape [203].

In our laboratory [7], we tested the hypothesis that cells would loose resistance upon ALAPDT of cells in suspension, based on the observation that resistant clones spread more than the parental cell line. In this study we also observed that the resistance indices of the cells did not change. ALA-PDT was also performed in cells attached to fibronectin, but no differences in the resistant indices of the clones were observed.

Cell size has been suggested to be somewhat related to resistance to chemotherapy [204]. Similarly, there are some evidences that cell size can be related to PDT resistance as well. PII-PDT resistant variants from RIF fibrosarcoma cells [6] were larger and had an increased 
protein content; similar to the resistant variants isolated by Sharkley et al. [44]. An increased cell spreading together with an increased number of cells per colony was also observed. In addition, when several human leukemia cell lines and normal lymphocytes were tested, it was found that the resistance to BPD-MA-PDT was related to the cell sizes, with the smallest cells being the most vulnerable [205]. We also found [7] a 2-fold increase in the volume and protein content of ALA-PDT resistant variants as compared to the parental line. Similarly, plasma membrane is the main target for PDT damage [206] and since larger cells have a greater surface area, the treatment could be less effective in the resistant clones.

\section{INDUCTION OF CYCLOOXYGENASES}

Cyclooxygenases (COX) catalyze the conversion of arachidonic acid to prostaglandin (PG) $\mathrm{H}_{2}$, the immediate substrate for a number of cell specific prostaglandin and tromboxane synthases. The production and release of Prostaglandin PGE2 and other prostanoids contribute to the development of important immunomodulatory responses. Two isoforms, COX-1 and COX-2, have been identified and their expression is regulated differently. COX-1 is constitutively expressed in most cell types and may be responsible for housekeeping functions. By contrast, the expression of COX-2, which is regulated both at the transcriptional and post-transcriptional level, is barely detectable in normal tissues but is rapidly induced in response to tumor promoters, oncogenes, cytokines, and mitogens [207209]. A growing body of evidence suggests an association of COX-2 with tumor development, aggressive biological tumor behavior, resistance to standard cancer treatment, and adverse patient outcome [210].

Controversial results have been observed in cancer cells with modulated metabolism of arachidonic acid prior to PDT. It was found that PDT employing porphyrin- and chlorinbased photosensitizers induces the expression of COX-2 with subsequent release of PGE2 [211, 212]. Conversely, the combination of PDT with the selective NS-398 COX-2 inhibitor, resulted in enhanced photodamage in RIF-1 fibrosarcomas [211]. Similarly, Henderson and Donovan [213] and Penning et al.. [214] demonstrated that non specific COX-2 inhibitor indomethacin increased the sensitivity of tumor cells to PDT. At the same time NS-398 caused upregulation of COX-2 and induced apoptosis resistance in HeLa cells on hypericinPDT [212, 215]. On the other hand, Kleban et al., [216] found that the arachidonic acid inhibitors inhibitors with known COX-independent action potentiated Hypericin-PDT, and the inhibitors of COX attenuated PDT. PII-PDT also induced the expression of COX-2 gene in C-26 cells [217]. The study also showed that the administration of a selective COX-2 inhibitor potentiated antitumor effects after PDT, but not during or before PDT.

Some recent reports have implicated p38 MAPK in the upregulation of the inducible COX-2. Overexpression of WT-p38 MAPK increased cellular resistance to PDT-induced apoptosis by blocking COX-2 up-regulation [212]. Phospholipase A2 inhibition caused an increase in the levels of free arachidonic acid, protected bladder cancer cells from Hypericin-PDT mediated apoptosis and attenuated the activation of p38 MAPK [215].

On the other hand, the inhibitor of endogenous PG synthesis indomethacin, increased resistance of glioma cells to PDT. The endothelial cells did not show an increase in resistance. In contrast to the studies performed using radiotherapy, exogenous PGs decreased the surviving fraction of human endothelial cells and glioma C6 cells treated by PII-PDT [218].

Kleban et al. [216] modulated arachidonic acid metabolism prior to Hypericin-PDT. They found the inhibition of lipooxigenase (LOX) activity upon PDT. The combination of lowdose Hypericin-PDT and 5, 12-LOX and 12-LOX inhibitors intensively strikes cell survival and proliferation. 


\section{NITRIC OXIDE}

Nitric oxide (NO) is a gaseous radical that can play either a cytotoxic or a cytoprotective role depending on the cell type and the experimental paradigm selected in the pathology.

Several pathways were found to be involved in chemoresistance mediated by NO. In malignant astrocytes, NO has been found to modulate radioresistance and chemoresistance against nitrosourea derivatives [219]. In neuroblastoma cells, NO inhibition of the transcription factor and proto-oncogene NMYC activity and expression of a large set of ATP binding cassette transporters influence the chemoresistance phenotype [220]. Inducible NO synthase also confers chemoresistance in head and neck cancer by modulating survivin [221]. In cisplatin-resistant ovarian cancer cells, blocking all NO synthases dramatically reverses the resistant phenotype through induction of apoptosis [222].

NO itself is not an effective oxidant, but can be converted to strong damaging oxidants under biological conditions. However, $\mathrm{NO}$ on its own may act as an antioxidant at low concentrations in lipid membranes by scavenging chain propagating oxyl and peroxyl radicals [223]. Radical interception by NO could contribute to overall cellular resistance to peroxidative stress. If this occurs during PDT, it might compromise treatment efficacy. Niziolek et al. [224] showed that photokilling, could be strongly suppressed by low, nontoxic levels of exogenous NO.

NO can elicit long-term cytoprotective antioxidant responses. The effects in this case are indirect; i.e., responsible NO is no longer on the scene when the oxidative challenge is presented. For example, endogenous NO produced via cytokine induction of nitric oxide synthase elicited similar long-term hyperresistance to $\mathrm{H}_{2} \mathrm{O}_{2}$ or high-level $\mathrm{NO}$ cytoxicity in hepatocytes $[225,226]$.

Similarly, hyperresistance to ALA-PDT was detected approximately $8 \mathrm{~h}$ post SPNO (exogenous NO donor), and maximized approximately after $20 \mathrm{~h}$ [227]. And in addition to its immediate radical-quenching effects, NO can evoke a delayed cytoprotective response in PpIX-sensitized COH-BR1 cells, since a concomitant increase in HO-1 levels and ferritin was observed. This observation suggested that a cytoprotective mechanism with mobilization of "signaling" iron was involved. The same group reported in 2010 [227] that NO has remarkable ability to support apoptosis. COH-BR1 tumor cells in glucosecontaining medium died after ALA-PDT mainly due to necrosis with a low level of apoptosis. SPNO inhibited necrosis when introduced before PDT treatment at a nontoxic concentration but supported apoptosis such that the latter became predominant in the remaining cell death. Accompanying this was a large increase in caspase-3/7 activation. SPNO-supported apoptosis was more pronounced when glucose-deprived cells were compared with glucose-replenished, SPNO-treated counterparts. SPNO plus glucose also suppressed plasma membrane-damaging lipid peroxidation and loss of cellular ATP under photostress. The NO effect on PDT resistance is attributed to membrane protection with maintenance of sufficient glycolytic ATP to sustain apoptosis. They have also extrapolated the results of NO protection to PDT with other PS such as MC540 [228], a lipophilic dye that localizes primarily in the plasma membrane. Photodamage of MC540-sensitized mouse lymphocytic leukemia L1210 cells was inhibited when SPNO was introduced either immediately before or after light exposure. The mechanism of protection is related to interceptation of propagating radicals such as 5alpha-OOH, definitive singlet oxygen adduct of plasma membrane cholesterol.

In our laboratory [229] we found that the NO-resistant variant of murine breast adenocarcinoma LM3-SNP obtained after successive exposures to the NO donor sodium nitroprusside had no cross-resistance to ALA-PDT treatment. We have also induced 
resistance to ALA-PDT in LM3-SNP cells after multiple cycles of photodynamic treatment, showing that resistance to NO did not interfere in the development of PDT resistance. In addition, we found that various cell lines with different NO production levels were equally responsive to ALA-PDT [230]. Furthermore, the modulation of NO levels did not modify the intrinsic response of various cells lines to PDT treatment.

Bhowmick [231] et al. reported evidence for increased tumor cell resistance due to inducible NO synthase (iNOS) upregulation in a PDT model. After ALA-PDT treatment of breast tumor COH-BR1 cells, iNOS was upregulated, while other NOS isoforms were unaffected. Exposing cells to the NOS inhibitor L-NAME during photochallenge enhanced caspase-3/7 activation and apoptotic killing, suggesting that iNOS was cytoprotective. Consistently, a NO scavenger enhanced ALA-PDT-induced caspase-3/7 activation and apoptotic death.

\section{SURVIVIN}

Discovered 10 years ago, survivin has a dual role in the smooth progress of mitosis and in apoptosis resistance. Survivin plays an important physiological role in development, but it is absent in differentiated adult tissues. In contrast, aberrant survivin expression is found in most human cancers because of the activation of various signaling pathways. A complex survivin network appears to intersect multiple pathways in cell biology, related to several molecular partners and fine subcellular localizations. Based on its pro-oncogenic properties, basic and translational studies have shown a growing interest in survivin that has led to consider it as a prognostic marker and a promising target for anti-tumoral therapies. Initially, survivin was described as an inhibitor of caspase-9. However, over the last years, research studies have shown that the role of survivin in cancer pathogenesis is not limited to apoptosis inhibition but it also involves the regulation of the mitotic spindle checkpoint. Survivin also promotes angiogenesis and chemoresistance [232]. In various tumors, high survivin levels are correlated with poor prognosis, decreased apoptosis, increased angiogenesis, and chemoresistance in cancer cells [233, 234].

Survivin binds to HSP90 in cells and is therefore considered a HSP90 client protein [235]. HSP90 provides the necessary intracellular chaperone environment for proper folding and maturation of a variety of client proteins, many of which are involved in signal transduction and cell proliferation. A derivative of the antibiotic Geldanamycin, 17-allylamino-17demethoxygeldanamycin (17-AAG), interferes with proper binding of client proteins, such as survivin and leads to misfolding of client proteins, ubiquination, and proteasome degradation.

Ferrario et al. [236] found in the human melanoma cell line YUSAC2/T34A-C4 that PII and chlorin-based PDT induced increased expression and phosphorylation of survivin together with increased PDT-mediated apoptosis and cytotoxicity. PDT treatment of melanoma cells expressing an inducible dominant-negative survivin gene, resulted in increased cleavage of the caspase substrate.

In addition, human BT-474 breast cancer cells treated with the combination of PDT and 17AAG exhibited decreased expression of phosphorylated survivin, phosphorylated Akt, and Bcl-2. The decreased expression of these client proteins was accompanied by higher apoptotic indices and increased cytotoxicity, showing for the first time that targeting survivin and possibly other HSP90 client proteins improves PDT responsiveness in vitro [236].

ALA-PDT induced apoptosis and G0/G1 phase arrest in cervical cancer Me180 cells. ALAPDT also suppressed the mRNA and protein expression of survivin in Me180 cells [237]. 
Immunohistochemistry of ALA-PDT treated Me180 tumors showed remarkable downregulation of protein expression and mRNA of survivin [238].

Ferrario, [239] examined the effects of a combined modality protocol involving PDT and 17-AAG in mouse mammary carcinoma cells and tumors. PDT increased the expression of the anti-apoptotic and pro-angiogenic proteins survivin, Akt, HIF1-alpha, MMP-2 and VEGF in tumor tissue and 17-AAG significantly decreased the protein expression. Tumor bearing mice treated with PDT and 17-AAG had improved long-term tumoricidal responses when compared with individual treatment protocols. In conclusion, survivin has recently shown to be involved indirectly in resistance to PDT, and at the same time, as a target for PDT. However, to the best of our knowledge, upregulation of survivin was not found in PDT resistant cells.

\section{HYPOXIA}

Tumor hypoxia is a therapeutic concern since it can reduce the effectiveness of radiotherapy, some $\mathrm{O}_{2}$-dependent cytotoxic agents, and photodynamic therapy [240]. Tumor hypoxia can also negatively impact therapeutic outcome by inducing changes in the proteome and genome of neoplastic cells. Tumor hypoxia enhances survival and malignant progression by enabling the cells to overcome nutrient deprivation or to escape their hostile environment. The selection and clonal expansion of these favorably altered cells further aggravate tumor hypoxia and support a vicious circle of increasing hypoxia and malignant progression while concurrently promoting the development of a more treatment-resistant disease.

PDT-induced tissue hypoxia as a result of vascular damage and photochemical oxygen consumption may limit the efficacy of this treatment. A mechanism that protect tumor cells against PDT-mediated damage is stabilization of hypoxia-inducible factor1 (HIF1)-alpha [131,241]. It was reported that PDT induces hypoxia and expression of the vascular endothelial growth factor (VEGF) via the HIF1-alpha pathway, with subsequent promotion of tumor angiogenesis, thus enhancing tumor proliferation and survival. By DNA microarray analysis Okunaka et al. [242] demonstrated that VEGF mRNA expression was induced in the lung cancer cell line SBC-3 after ATX-s10-PDT.

Human esophageal normal Het-1A cell line induced with high-expression of HIF-1alpha by cobalt chloride-mediated chemical, clearly showed resistance to ALA-PDT. Moreover, transfection of the cells with anti-HIF1-alpha short interfering RNA (siRNA) knocked down the HIF-1alpha expression and restored the photosensitivity of the cells to ALA-PDT. However, HIF-1alpha expression was not induced by cobalt chloride in tumour esophageal KYSE-70 and KYSE-450 cell lines, and hence no difference in cell survival was found after ALA-PDT [179].

Some strategies have been developed in order to overcome PDT resistance due to hypoxia. It has been hypothesised [243] that by controlled temporary endo or peri-vascular occlusion of the collateral arterial branches upstream of the tumor, it is possible to redirect blood flow through the principal artery of the downstream tumor. The concept called "arterial flow focalization" increase oxygen supply, thus decreasing hypoxia-driven resistance to PDT. In addition, hypoxic cells can be also a preferential target of bioreductive drugs and hypoxiadirected gene therapy [244, 245].

\section{CROSS-RESISTANCE BETWEEN PDT AND OTHER THERAPIES}

Several investigators have looked into PDT susceptibility of cells resistant to various anticancer treatments (Table 4). Particularly, cells with either induced or transfected MDR have been tested for cross resistance with PDT, however these results have been conflicting. 
Some cells resistant to chemotherapy were found to be slightly more susceptible to PDT [52, 246, 247]. In general, about one third of the reports showed cross resistance to PDT in chemotherapy, radiotherapy and hyperthermia resistant cells, whereas the rest of the models showed no resistance.

In addition, some researchers have challenged if cell lines resistant to PDT are also resistant to chemotherapy, radiotherapy or hyperthermia (Table 5). Again, some cell lines were found to be cross resistant and others were not. One third of reports showed cross resistance and two thirds showed no cross resistance to chemotherapy etc in PDT resistant cells. In our laboratory, we found that ALA-PDT resistant clones were not resistant either to UV and hyperthermia treatment or to chemotherapy with DXR, cisplatin, methotrexate, 5Fluorouracil and Mitomycin C treatment [7].

In the particular case of cross resistance to cisplatin, a 2-fold decrease in the number of platinum-DNA adducts were found, when the PII-PDT resistant cells RIF-8A were exposed to the drug [48]. Since several mitochondrial alterations have been described for this cell line with subsequent resistance to antineoplastic treatment, the authors hypothesize that an increased repair activity could result in an increased energy demand, and consequently a higher mitochondrial activity.

Cisplatin resistance-associated overexpressed protein (LUC7A) was cloned by Nishii et al. [248] from cisplatin-resistant cell lines. LUC7A mRNA was down-regulated in the colon cancer cell line HT29 after ALA-PDT and not regulated in two bladder cancer cell lines [92]. The fact that cisplatin resistance was not induced after PDT in those cell lines may provide a basis for combinatory therapy regimens. Lottner et al. [249] combined the cytostatic activity of cisplatin/oxaliplatin and the photodynamic effect of hematoporphyrin in the same molecule employing hematoporphyrin-platinum(II) conjugates. They found synergistic antiproliferative effects in vitro against J82 bladder cancer cells and UROtsa using four different hematoporphyrin-platinum(II) conjugates (Fig 9).

A PDT-mediated DXR transient resistance has been described for Chinese hamster fibroblasts after a single treatment of PII-PDT under short or long exposure times to the PS [250]. ATP depletion and cell cycle changes were positively correlated with decrease in drug sensitivity. However, induction of glucose-regulated stress proteins, antioxidant enzymes activities and intracellular drug levels were not responsible for the drug resistance.

Guo et al. [251] found that breast cancer MCF-7 cells resistant to paclitaxel and doxorubicin treatment were efficiently treated with the photoactivable drug calphostin $\mathrm{C}$, through a mechanism that involves the induction of cytoplasmic vacuolization without activation of typical apoptotic pathways. Calphostin C, is not a classical PS, but it is a photoactivable inhibitor of phorbol-responsive protein kinase $\mathrm{C}$ isoforms [252].

Cross resistance of PDT resistant cells to UV light has been shown by DiProspero et al. [81] and Zacal et al. [125]. There are differences in sensitivity according to the UV illumination wavelength. For example, PDT-resistant HT29 human colon adenocarcinoma cells were cross-resistant to long-wavelength UVA (320-400 nm) but not to short-wavelength UVC $(200-280 \mathrm{~nm})$. The authors found that increased expression of Hsp27 and BNip3 and decreased expression of mutant p53 correlated with increased resistance to UVA. In contrast, increased expression of Hsp27 and BNip3 correlated with increased sensitivity to UVC, whereas increased expression of mutant p53 showed no significant correlation with sensitivity to UVC [253]. 
The study of cross resistance in cells with developed resistance against a particular PS challenged against other PS of similar or different characteristics (Table 6) is highly complex. Often cross-resistance is related to the structure of the PS.

The PII-PDT resistant RIF-8A cells were cross resistant to incubation with PpIX but not to ALA-induced PpIX, implying that the differences in mitochondrial localization and/or binding depending on the source of PpIX may be crucial in the outcome of PDT. Upon incubation of RIF-8A cells with ALA, PpIX fluorescence was higher than that obtained in the parental RIF-1 cells. Subcellular localization of PpIX was quite similar in both the strains. In addition a good correlation with Rhodamine123 fluorescence was observed in both lines. On the contrary, when exogenous PpIX was added, a strong correlation was seen in parental RIF-1 cells with Rh-123 fluorescence, but a weak correlation was found in RIF-8A cells between exogenous PpIX and mitochondrial sites [26].

We found that our ALA-PDT resistant clones from mammary carcinoma cells exhibited a slight resistance to exogenous protoporphyrin IX treatment but no cross resistance to BPDMA and MC540 photosensitization. However intracellular accumulation of the three PS per protein was equal in both parental and resistant clones, showing that PS content is not crucial for photodynamic resistance in all the cases [7]. ALA ester derivatives hexyl-ALA and undecanoyl-ALA did show cross resistance with ALA-PDT (Fig 10), although both lypophyllic ALA derivatives do not enter the cell through the same transporter [254] and are probably not effluxed by the same mechanism [255]. This reinforces the hypothesis that cross resistance depends on PpIX formed from ALA or ALA derivatives and not ALA itself.

Mayhew et al. [4] found that the strains resistant to PDT with the anionic compound PHP exhibited cross resistance to other anionic PS such as i) exogenous PpIX, ii) Zn (II) tetrasulphonated phthalocyanine (TSPC) and iii) Zn (II) tetraglycine-substituted phthalocyanine (TGly) (Fig 11). However, the PHP-PDT resistant cells were not resistant to PDT with the cationic PS Zn-PCP and m-THPC, the neutral PS mTPyP (Fig 12) and PpIX from ALA.

However, the resistant variants to PDT with the cationic PS Zn-PCP did not exhibit cross resistance to any of the PS employed above mentioned PS, either the anionic (Fig 11) or the neutral and cationic (Fig 12). The conclusion of these studies was that there are at least two distinct mechanisms of PDT-resistance in these RIF-1 cells, and that the PHP-resistance is likely to depend, to some extent, upon the physical nature of the PS. Zn-PCP resistant RIF-1 cells are, on the contrary, not cross resistant to any other PS, and this is likely to be due to the alteration of a single cellular target, which is not shared with any other PS.

Luna \& Gomer [6] found that the 16 h-PII PDT-resistant variants exhibited cross-resistance to a $1 \mathrm{~h}$-PII PDT incubation protocol. The short incubation of PS is generally associated with plasma membrane damage, whereas extended incubation is usually believed to result in damage to specific cellular organelles $[6,256]$. However, the $1 \mathrm{~h}$ PII PDT-resistant variants did not exhibit resistance to the extended $16 \mathrm{~h}$ PII incubation PDT protocol. Mayhew et al. [4] found in their resistant variants, cross-resistance to short exposure to PHP (a compound equivalent to PII) and long exposure protocols. Such varying results employing similar PS suggest that the mechanisms of resistance are multiple and different for each induction protocol. 


\section{DO PDT RESISTANT CELLS AND CHEMORESISTANT CELLS SHARE THE MECHANISMS OF RESISTANCE?}

Nearly any type of chemoresistances is a multifactorial process involving induction of drugdetoxifying mechanism, quantitative and qualitative modification of drug targets, arrest of cell cycle, regulation of DNA replication or reparation mechanisms, and modulation of apoptosis. These modifications are acquired in response to a selection pressure by the drug treatment (acquired resistance) or expressed by cells already resistant and that will never respond to the drug treatment (intrinsic resistance). The specific mechanisms for chemoresistance have been extensively reviewed elsewhere [257, 258, 259].

Table 7 compares the mechanisms of resistance to PDT and chemotherapy. Although there are specific causes of PDT resistance, most of the features of PDT resistance have already been described for chemoresistance. The fact that in many cases no cross-resistance has been reported between both the treatments is in line with the enhancement of PDT efficacy by combination with chemotherapy [260-266]. On the other hand, in many cases, the same common features can be induced by different but overlapping pathways which can lead to cross resistance.

\section{CONCLUSIONS AND FUTURE DIRECTIONS}

As in chemo- and radiation resistance, the mechanisms of resistance associated with PDT are complex and are reviewed in this article. The salient aspects of PDT-induced resistance mechanisms discussed here are: i) induction of resistance after multiple PDT treatments, ii) modulation of protein expression leading to resistance, iii) induction of specific genes involved in the mechanisms of resistance, and iv) studies of alterations in gene expression after PDT treatment.

An understanding of these resistant mechanisms could potentially help design new and robust treatments strategies such as combination of PDT with chemo or other therapies. Although chemoresistance is well established, in many cases, no cross-resistance between PDT and chemotherapy has been reported. For example, protective mechanisms such as damage to DNA repair help the chemotherapy escape process, but this resistance mechanism is very limited in PDT treated cells. In addition, the new cDNA array techniques provide the tools to further study the role of multiple survival pathways, demonstrating that PDT resistance, similar to chemoresistance, is a multifactorial phenomenon. The lack of cross resistance between PDT treatments with different PS in many studies confirms the complexity of the resistance processes and the specificity of the cell death pathways with each PS. As PDT evolves into a first line therapy, it is crucial to understand these resistance mechanisms and develop efficient treatment strategies to overcome these.

\section{Acknowledgments}

The authors would like to thank the CONICET and the Agencia Nacional de Promoción Científica y Tecnológica (PICT 2008-0047 and PICT 2006-1809) for finantial assistance. TH acknowledges finantial support from PO1 CA084203 and RC1CA146337 grants.

\section{Abbreviations}

17-AAG 17-allylamino-17-demethoxygeldanamycin

ABC ATP-binding cassette

ALA 5-aminolevulinic acid 


\begin{tabular}{|c|c|}
\hline AlS2PC & aluminium disulphonated phthalocyanine \\
\hline AP-1 & activator protein- 1 \\
\hline BCRP & breast cancer resistant protein \\
\hline BPD-MA & Benzoporphyrin Derivative monoacid ring A \\
\hline CAM-DR & cell adhesion-mediated drug resistance \\
\hline Cam-ks & calcium/calmodulin-dependent kinases \\
\hline COX & cyclooxygenase \\
\hline CPO & [9-capronyloxy-tetrakis(methoxyethyl) porphycene] \\
\hline $\mathbf{C R}$ & cross resistant \\
\hline DADP-a & 5,10-di[4-(N-trimethylaminophenyl)-15,20-diphenylporphyrin \\
\hline DADP-o & 5,15-di[4-(N-trimethylaminophenyl)-10,20-diphenylporphyrin \\
\hline DXR & doxorrubicin \\
\hline $\mathbf{E C M}$ & extracellular matrix \\
\hline Etk & epithelial and endothelial tyrosine kinase \\
\hline $\mathbf{E R}$ & endoplasmic reticulum \\
\hline ERK & extracellular signal regulated kinases \\
\hline FADD & Fas-associated via death domain \\
\hline GDF15 & growth and differentiation factor 15 \\
\hline GRP & glucose regulated protein \\
\hline HIF1 & hypoxia-inducible factor 1 \\
\hline HO-1 & heme oxygenase 1 \\
\hline HSP & heat shock proteins \\
\hline НРPH & 2-(1-hexyloxethyl)-2-devinyl pyropheophorbide-a \\
\hline iNOS & inducible NO synthase \\
\hline LOX & lipooxigenase \\
\hline $\mathbf{L U C 7 A}$ & Cisplatin resistance-associated overexpressed protein \\
\hline MAPK & mitogen-activated protein kinase \\
\hline MCP & monoctionic porphyrin \\
\hline MC540 & merocyanin 540 \\
\hline MDR & multidrug resistance \\
\hline m-THPC & meta-tetra(hydroxyphenyl)chlorin \\
\hline MRP1 & multidrug resistant associated protein 1 \\
\hline mTPyP & meso-tetra (4-pyridyl) porphine \\
\hline m-THPC & 5,10,15,20-tetra(meta-hyroxyphenyl) chlorin \\
\hline m-THPP & meso-tetra(3-hydroxyphenyl)porphyrin \\
\hline NAO & ION-nonyl acridine orange \\
\hline
\end{tabular}




\begin{tabular}{ll} 
NO & nitric oxide \\
NPe6 & Mono-L-aspartyl chlorin e6 \\
NR & nonresistant \\
UPS & ubiquitin-proteasome system \\
PCI & photochemical internalisation \\
P-gp & P-glycoprotein \\
PDT & Photodynamic Therapy \\
PI3K & Phosphatidylinositol 3-kinase \\
PpIX & Protoporphyrin IX \\
PS & photosensitizer \\
Pc4 & Phthalocyanine 4 \\
PII & Photofrin II \\
PHP & polyhematoporphyrin \\
PG & prostaglandin \\
SMS & sphingomyelin synthases \\
SnET2 & tin ethyl etiopurpurin I \\
SOD & superoxide dismutase \\
SPNO & spermine NONOate \\
TOOKAD & palladium-bacteriopheophorbide WST09 \\
TPPS2a & disulfonated meso-tetraphenylporphine \\
TSPC & Zn (II) tetrasulphonated phthalocyanine \\
TGly & Zn (II) tetraglycine-substituted phthalocyanine \\
VEGF & vascular endothelial growth factor \\
Zn-PC & Zn-phthalocyanine \\
Zn-PCP & zinc (II) pyridinium-substituted phthalocyanine \\
& \\
\hline
\end{tabular}

\section{References}

1. Gomer, CJ. Photodynamic Therapy. Pergamon Press; Oxford, England: 1987.

2. Dougherty TJ. Photodynamic Therapy-new approaches. Semin Surg Oncol. 1989; 5:6-16. [PubMed: 2652248]

3. Weishaupt K, Gomer C, Dougherty T. Identification of singlet oxygen as the cytotoxic agent in photoactivation of a murine tumour. Cancer Res. 1976; 36:2326-2329. [PubMed: 1277137]

4. Mayhew S, Vernon D, Schofield J, Griffiths J, Brown S. Investigation of cross-resistance to a range of photosensitizers, hyperthermia and UV light in two radiation-induced fibrosarcoma cell strains resistant to photodynamic therapy in vitro. Photochem Photobiol. 2001; 73:39-46. [PubMed: 11202364]

5. Singh G, Wilson B, Sharkey S, Browman G, Deschamps P. Resistance to photodynamic therapy in radiation induced fibrosarcoma-1 and chinese hamster ovary-multi-drug resistant cells in vitro. Photochem Photobiol. 1991; 54:307-312. [PubMed: 1838198]

6. Luna M, Gomer C. Isolation and initial characterization of mouse tumor cells resistant to porphyrinmediated photodynamic therapy. Cancer Res. 1991; 51:4243-4249. [PubMed: 1831066] 
7. Casas A, Perotti C, Ortel B, Di Venosa G, Saccoliti M, Batlle A, Hasan T. Tumor cell lines resistant to ALA-mediated photodynamic therapy and possible tools to target surviving cells. Int J Oncol. 2006; 29:397-405. [PubMed: 16820882]

8. Henderson B, Miller A. Effects of scavengers of reactive oxygen and radical species on cell survival following photodynamic treatment in vitro: comparison to ionizing radiation. Radiat Res. 1986; 108:196-205. [PubMed: 3097749]

9. Gomer C, Ryter S, Ferrario A, Rucker N, Wong S, Fisher A. Photodynamic Therapy-mediated oxidative stress can induce the expression of heat shock proteins. Cancer Res. 1996; 56:2355-2360. [PubMed: 8625311]

10. Shackley DC, Haylett A, Whitehurst C, Betts CD, O'Flynn K, Clarke NW, Moore JV. Comparison of the cellular molecular stress responses after treatments used in bladder cancer. BJU Int. 2002; 90:924-932. [PubMed: 12460358]

11. Ruhdorfer S, Sanovic R, Sander V, Krammer B, Verwanger T. Gene expression profiling of the human carcinoma cell line A-431 after 5-aminolevulinic acid-based photodynamic treatment. Int J Oncol. 2007; 30:1253-1262. [PubMed: 17390029]

12. Adams K, Rainbow A, Wilson B, Singh G. In vivo resistance to Photofrin-mediated Photodynamic Therapy in radiation-induced fibrosarcoma cells resistant to in vitro Photofrin-mediated Photodynamic therapy. J Photochem Photobiol. 1999; 49:136-141.

13. Morgan J, Potter WR, Oseroff AR. Comparison of photodynamic targets in a carcinoma cell line and its mitochondrial DNA-deficient derivative. Photochem Photobiol. 2000; 71:747-57. [PubMed: 10857372]

14. Peng Q, Moan J, Farrants GW, Danielsen HE, Rimington C. Location of P-II and AlPCS4 in human tumor LOX in vitro and in vivo by means of computer-enhanced video fluorescence microscopy. Cancer Lett. 1991; 58:37-47. [PubMed: 1828713]

15. Lin CW, Shulok JR, Kirley SD, Cincotta L, Foley JW. Lysosomal localization and mechanism of uptake of Nile blue photosensitizers in tumor cells. Cancer Res. 1991; 51:2710-2719. [PubMed: 2021950]

16. Van Hillesberg R, van der Berg J, Kort W, Terpstra O, Wilson J. Selective accumulation of endogenously produced porphyrins in a liver metastasis model in rats. Gastroenterology. 1992; 103:647-651. [PubMed: 1386052]

17. Navone N, Polo C, Frisardi A, Batlle A. Mouse mammary carcinoma PBGase and hydroxymethylbilane synthetase. Comp Biochem Physiol B. 1991; 98:67-71. [PubMed: 2060282]

18. Madsen SJ, Sun CH, Tromberg BJ, Hirschberg H. Repetitive 5-aminolevulinic acid-mediated photodynamic therapy on human glioma spheroids. J Neurooncol. 2003; 62:243-250. [PubMed: 12777075]

19. Calzavara-Pinton P. Repetitive photodynamic therapy with topical delta-aminolaevulinic acid as an appropriate approach to the routine treatment of superficial non-melanoma skin tumours. $\mathrm{J}$ Photochem Photobiol B. 1995; 29:53-57. [PubMed: 7472803]

20. Salim A, Leman J, McColl J, Chapman R, Morton C. Randomized comparison of photodynamic therapy with topical 5-fluoruracil in Bowen's disease. Br J Dermatol. 2003; 148:539-543. [PubMed: 12653747]

21. Willey A, Mehta S, Lee PK. Reduction in the Incidence of Squamous Cell Carcinoma in Solid Organ Transplant Recipients Treated with Cyclic Photodynamic Therapy. Dermatol Surg. 2010; 36:652-658. [PubMed: 19889154]

22. Mathews MS, Angell-Petersen E, Sanchez R, Sun CH, Vo V, Hirschberg H, Madsen SJ. The effects of ultra low fluence rate single and repetitive photodynamic therapy on glioma spheroids. Lasers Surg Med. 2009; 41:578-584. [PubMed: 19731298]

23. Luna M, Ferrario A, Rucker N, Gomer C. Decreased expression and function of alpha-2 macroglobulin receptor/low density lipoprotein receptor-related protein in photodynamic therapyresistant mouse tumor cells. Cancer Res. 1995; 55:1820-1823. [PubMed: 7728745]

24. Bernal S, Shapiro H, Chen L. Monitoring the effect of anticancer drug on L1210 cells by a mitochondrial probe, rhodamine 123. Int J Cancer. 1982; 30:219-224. [PubMed: 7129675] 
25. Maftah A, Petit J, Rainaud M, Julien R. 10-N nonyl acridine orange: a fluorescent probe which stains mitochondria independently of their energetic state. Biochem Biophys Res Commun. 1989; 164:185-190. [PubMed: 2478126]

26. Wilson B, Olivo M, Singh G. Subcellular localization of Photofrin and aminolevulinic acid and Photodynamic cross-resistance in vitro in radiation-induced fibrosarcoma cells sensitive or resistant to Photofrin-mediated Photodynamic Therapy. Photochem Photobiol. 1997; 65:166-176. [PubMed: 9066298]

27. Hilf R, Smail D, Murant R, Leakey P, Gibson S. Hematoporphyrin derivative induced photosensitivity of mitochondrial succinate dehydrogenase and selected cytosolic enzymes of R3230AC mammary adenocarcinomas of rats. Cancer Res. 1984; 44:1483-1488. [PubMed: 6231099]

28. Nelson JS, Sun CH, Berns MW. Study of the in vivo and in vitro photosensitizing capabilities of uroporphyrin I compared to photofrin II. Lasers Surg Med. 1986; 6:131-136. [PubMed: 2941630]

29. Okunaka T, Eckhauser ML, Kato H, Bomaminio A, Yamamoto H, Aizawa K, Sarasua MM, Koehler KA. Correlation between photodynamic efficacy of differing porphyrins and membrane partitioning behavior. Lasers Surg Med. 1992; 12:98-103. [PubMed: 1535406]

30. Strauss WS, Sailer R, Schneckenburger H, Akgun N, Gottfried V, Chetwer L, Kimel S. Photodynamic efficacy of naturally occurring porphyrins in endothelial cells in vitro and microvasculature in vivo. J Photochem Photobiol. 1997; 39:176-184.

31. Musser DA, Oseroff AR. The use of tetrazolium salts to determine sites of damage to the mitochondrial electron transport chain in intact cells following in vitro photodynamic therapy with Photofrin II. Photochem Photobiol. 1994; 59:621-626. [PubMed: 8066121]

32. Hilf R. Mitochondria are targets of photodynamic therapy. J Bioenerg Biomembr. 2007; 39:85-89. [PubMed: 17334915]

33. Boegheim JP, Lagerberg JW, Dubbelman TM, Tijssen K, Tanke HJ, Van Der Meulen J, Van Steveninck J. Photodynamic effects of hematoporphyrin derivative on the uptake of rhodamine 123 by mitochondria of intact murine L929 fibroblasts Chinese ovary K1 cells. Photochem Photobiol. 1988; 48:613-620. [PubMed: 2977224]

34. Salet C, Moreno G. Photosensitization of mitochondria. Molecular and cellular aspects. J Photochem Photobiol B: Biol. 1990; 5:133-150.

35. Moor AC. Signaling pathways in cell death and survival after photodynamic therapy. J Photochem Photobiol B. 2000; 57:1-13. [PubMed: 11100832]

36. Kessel D. Death pathways associated with photodynamic therapy. Med Laser Appl. 2006; 21:219224. [PubMed: 19890442]

37. Denis-Pouxveil C, Riesinger I, Buhler C, Brdiczka D, Murat J. Regulation of mitochondrial hexokinase in cultured HT29 human cancer cells. An ultrastructural and biochemical study. Biochim Biophys Acta. 1987; 902:335-348. [PubMed: 3620464]

38. Tumilowicz J, Nichols W, Cholon J, Greene A. Definition of a continuous human cell line derived from neuroblastoma. Cancer Res. 1970; 30:2110-2118. [PubMed: 5459762]

39. Zinkewich-Peotti K, Andrews P. Loss of cis-diamminedichloroplatinum(II) resistance in human ovarian cells selected fro rhodamine 123 resistance. Cancer Res. 1992; 52:1902-1906. [PubMed: 1551119]

40. Crawford DR, Wang Y, Schools GP, Kochheiser J, Davies KJ. Down-regulation of mammalian mitochondrial RNAs during oxidative stress. Free Radic Biol Med. 1997; 22:551-559. [PubMed: 8981048]

41. Shen XY, Zacal N, Singh G, Rainbow AJ. Alterations in mitochondrial and apoptosis-regulating gene expression in photodynamic therapy-resistant variants of HT29 colon carcinoma cells. Photochem Photobiol. 2005; 81:306-313. [PubMed: 15560738]

42. Singh K, Russell J, Sigala B, Zhang Y, Williams J, Keshav K. Mitochondrial DNA determines the cellular response to cancer therapeutic agents. Oncogene. 1999; 18:6641-6646. [PubMed: 10597269]

43. Wang X. The expanding role of mitochondria in apoptosis. Genes \& Development. 2001; 15:29222933. [PubMed: 11711427] 
44. Sharkey S, Wilson B, Moorehead R, Singh G. Mitochondrial alterations in Photodynamic Therapyresistant cells. Cancer Res. 1993; 53:4994-4999. [PubMed: 8402690]

45. Roninson IB, Chin JE, Choi KG, Gros P, Housman DE, Fojo A, Shen DW, Gottesman MM, Pastan I. Isolation of human mdr DNA sequences amplified in multidrug-resistant KB carcinoma cells. Proc Natl Acad Sci USA. 1986; 83:4538-4542. [PubMed: 3459187]

46. Gros P, Ben Neriah YB, Croop JM, Housman DE. Isolation and expression of a complementary DNA that confers multidrug resistance. Nature. 1986; 323:728-731. [PubMed: 3022150]

47. Lage H. An overview of cancer multidrug resistance: a still unsolved problem. Cell Mol Life Sci. 2008; 65:3145-3167. [PubMed: 18581055]

48. Moorehead R, Armstrong S, Wilson B, Singh G. Cross-resistance to cisplatin in cells resistant to Photofrin-mediated Photodynamic Therapy. Cancer Res. 1994; 54:2556-2559. [PubMed: 7909492]

49. Kessel D, Woodburn K, Skalkos D. Impaired accumulation of a cationic photosensitizing agent by a cell line exhibiting multidrug resistance. Photochem Photobiol. 1994; 60:61-63. [PubMed: 8073077]

50. Kessel D, Erickson C. Porphyrin photosensitization of multi-drug resistant cell types. Photochem Photobiol. 1992; 55:397-399. [PubMed: 1561237]

51. Robey RW, Steadman K, Polgar O, Bates SE. ABCG2-mediated transport of photosensitizers: potential impact on photodynamic therapy. Cancer Biol Ther. 2005; 4:187-194. [PubMed: 15684613]

52. Teiten M, Bezdetnaya L, merlin J, Bour-Dill C, Pauly M, Dicato M, Guillemin F. Effect of metatetra(hydrophenyl)chlorin (mTHPC)-mediated photodynamic therapy on sensitive and multidrugresistant human breast cancer cells. J Photochem Photobiol B. 2001; 62:146-152. [PubMed: 11566278]

53. Li W, Zhang W, Ohnishi K, Yamada I, Ohno R, Hashimoto K. 5-aminolevulinic acid-mediated photodynamic therapy in multidrug resistant leukemia cells. J Photochem Photobiol. 2001; 60:7986.

54. Chu ES, Yow CM, Shi M, Ho RJ. Effects of photoactivated 5-aminolevulinic acid hexyl ester on MDR1 over-expressing human uterine sarcoma cells. Toxicol Lett. 2008; 181:7-12. [PubMed: 18625294]

55. Tsai T, Hong RL, Tsai JC, Lou PJ, Ling IF, Chen CT. Effect of 5-aminolevulinic acid-mediated photodynamic therapy on MCF-7 and MCF-7/ADR cells. Lasers Surg Med. 2004; 34:62-72. [PubMed: 14755426]

56. Tang PM, Zhang DM, Xuan NH, Tsui SK, Waye MM, Kong SK, Fong WP, Fung KP. Photodynamic therapy inhibits P-glycoprotein mediated multidrug resistance via JNK activation in human hepatocellular carcinoma using the photosensitizer pheophorbide a. Mol Cancer. 2009; 8:56. [PubMed: 19646254]

57. Selbo PK, Weyergang A, Bonsted A, Bown SG, Berg K. Photochemical internalization of therapeutic macromolecular agents: a novel strategy to kill multidrug-resistant cancer cells. J Pharmacol Exp Ther. 2006; 319:604-612. [PubMed: 16902053]

58. Merlin JL, Gautier H, Barberi-Heyob M, Teiten MH, Guillemin F. The multidrug resistance modulator SDZ-PSC 833 potentiates the photodynamic activity of chlorin e6 independently of Pglycoprotein in multidrug resistant human breast adenocarcinoma cells. Int J Oncol. 2003; 22:733739. [PubMed: 12632062]

59. Preise D, Mazor O, Koudinova N, Liscovitch M, Scherz A, Salomon Y. Bypass of tumor drug resistance by antivascular therapy. Neoplasia. 2003; 5:475-480. [PubMed: 14965440]

60. Lou PJ, Lai PS, Shieh MJ, MacRobert AJ, Berg K, Bown SG. Reversal of doxorubicin resistance in breast cancer cells by photochemical internalization. Int J Cancer. 2006; 119:2692-2698. [PubMed: 16991130]

61. Adigbli DK, Wilson DG, Farooqui N, Sousi E, Risley P, Taylor I, Macrobert AJ, Loizidou M. Photochemical internalisation of chemotherapy potentiates killing of multidrug-resistant breast and bladder cancer cells. Br J Cancer. 2007; 97:502-512. [PubMed: 17667930]

62. Berg K, Selbo PK, Prasmickaite L, Tjelle TE, Sandvig K, Moan J, Gaudernack G, Fodstad O, Kjølsrud S, Anholt H, Rodal GH, Rodal SK, Høgset A. Photochemical internalization: a novel 
technology for delivery of macromolecules into cytosol. Cancer Res. 1999; 59:1180-1183. [PubMed: 10096543]

63. Doyle LA, Yang W, Abruzzo LV, Krogmann T, Gao Y, Rishi AK, Ross DD. A multidrug resistance transporter from human MCF-7 breast cancer cells. Proc Natl Acad Sci USA. 1998; 95:15665-15670. [PubMed: 9861027]

64. Allikmets R, Schriml LM, Hutchinson A, Romano-Spica V, Dean M. A human placenta-specific ATP-binding cassette gene (ABCP) on chromosome 4q22 that is involved in multidrug resistance. Cancer Res. 1998; 58:5337-5339. [PubMed: 9850061]

65. Doyle LA, Ross DD. Multidrug resistance mediated by the breast cancer resistance protein BCRP (ABCG2). Oncogene. 2003; 22:7340- 7358. [PubMed: 14576842]

66. Haimeur A, Conseil G, Deeley RG, Cole SP. The MRP-related BCRP/ABCG2 multidrug resistance proteins: biology substrate specificity regulation. Curr Drug Metab. 2004; 5:21-53. [PubMed: 14965249]

67. Jonker JW, Buitelaar M, Wagenaar E, Van Der Valk MA, Scheffer GL, Scheper RJ, Plosch T, Kuipers F, Elferink RP, Rosing H, Beijnen JH, Schinkel AH. The breast cancer resistance protein protects against a major chlorophyll-derived dietary phototoxin and protoporphyria. Proc Natl Acad Sci USA. 2002; 99:15649-15654. [PubMed: 12429862]

68. Tsunoda Y, Usuda J, Imai K, Kubota M, Maehara S, Ohtani K. The expression of BCRP/ABCG2 causes resistance to Photofrin-PDT. Jpn J Laser Surg Med. 2008; 28:355-361.

69. Robey RW, Steadman K, Polgar O, Morisaki K, Blayney M, Mistry P, Bates SE. Pheophorbide a is a specific probe for ABCG2 function and inhibition. Cancer Res. 2004; 64:1242-1246. [PubMed: 14973080]

70. Gupta N, Martin PM, Miyauchi S, Ananth S, Herdman AV, Martindale RG, Podolsky R, Ganapathy V. Down-regulation of BCRP/ABCG2 in colorectal and cervical cancer. Biochem Biophys Res Commun. 2006; 343:571-577. [PubMed: 16554028]

71. Liu W, Baer MR, Bowman MJ, Pera P, Zheng X, Morgan J, Pandey RA, Oseroff AR. The tyrosine kinase inhibitor imatinib mesylate enhances the efficacy of photodynamic therapy by inhibiting ABCG2. Clin Cancer Res. 2007; 13:2463-2470. [PubMed: 17438106]

72. Usuda J, Tsunoda Y, Ichinose S, Ishizumi T, Ohtani K, Maehara S, Ono S, Tsutsui H, Ohira T, Okunaka T, Furukawa K, Sugimoto Y, Kato H, Ikeda N. Breast cancer resistant protein (BCRP) is a molecular determinant of the outcome of photodynamic therapy (PDT) for centrally located early lung cancer. Lung Cancer. 2009; 67:198-204. [PubMed: 19477032]

73. Jendzelovský R, Mikes J, Koval' J, Soucek K, Procházková J, Kello M, Sacková V, Hofmanová J, Kozubík A, Fedorocko P. Drug efflux transporters, MRP1 and BCRP, affect the outcome of hypericin-mediated photodynamic therapy in HT-29 adenocarcinoma cells. Photochem Photobiol Sci. 2009; 8:1716-1723. [PubMed: 20024169]

74. Krishnamurthy P, Ross DD, Nakanishi T, Bailey-Dell K, Zhou S, Mercer KE, Sarkadi B, Sorrentino BP, Schuetz JD. The stem cell marker Bcrp/ABCG2 enhances hypoxic cell survival through interactions with heme. J Biol Chem. 2004; 279:24218-24225. [PubMed: 15044468]

75. Oleinick NL, Evans HH. The photobiology of photodynamic therapy: cellular targets and mechanisms. Radiat Res. 1998; 150(5 Suppl):S146-156. [PubMed: 9806617]

76. Gomer C. DNA damage and repair in $\mathrm{CHO}$ cells following hematoporphyrin photoradiation. Cancer Lett. 1980; 11:161-167. [PubMed: 7459844]

77. Fiel RJ, Datta-Gupta E, Mark E, Howard J. Induction of DNA damage by porphyrin photosensitizers. Cancer Res. 1981; 41:3543-3545. [PubMed: 7020932]

78. Ramakrishnan N, Oleinick N, Clay M, Horng M, Artunes A, Evans H. DNA lesions and DNA degradation in mouse lymphoma L5178Y cells after photodynamic treatment sensitized by chloroaluminium phthalocyanine. Photochem Photobiol. 1989; 50:373-378. [PubMed: 2780828]

79. Crute J, Walh A, Bambara R, Murant R, Gibson S, Hilf R. Inhibition of mammalian DNA polymerases by hematoporphyrin derivative and photoradiation. Cancer Res. 1986; 46:153-159. [PubMed: 3940188]

80. Evans H, Rerko R, Mencl J, Clay M, Artunez A, Oleinick N. Cytotoxic and mutagenic effects of the photodynamic action of chloroaluminium phthalocyanine and visible light in L5178Y cells. Photochem Photobiol. 1989; 49:43-47. [PubMed: 2717667] 
81. DiProspero L, Singh G, Wilson B, Rainbow A. Cross-resistance to Photofrin-mediated Photodynamic Therapy and UV light and recovery from Photodynamic Therapy damage in Rif-8A mouse fibrosarcoma cells measured using viral capacity. J Photochem Photobiol. 1997; 38:143151.

82. Gomer C, Rucker N, Murphree A. Transformation and mutagenic potential of porphyrin photodynamic therapy in mammalian cells. Int J Radiat Biol Relat Stud Phys Chem Med. 1988; 53:651-659. [PubMed: 2965114]

83. Schwarz V, Hornung R, Fedier A, Fehr M, Walt H, Haller U, Fink D. Photodynamic therapy of DNA mismatch repair-deficient and proficient tumour cells. Br J Cancer. 2002; 86:1130-1135. [PubMed: 11953861]

84. Crawford D, Zbinden I, Amstad P, Cerutti P. Oxidant stress induces the proto-oncogenes c-fos and c-myc in mouse epidermal cells. Oncogene. 1988; 3:27-32.

85. Buscher M, Rahmsdorf HJ, Litfin M, Karin M, Herrlich P. Activation of the c-fos gene by UV and phorbol ester: different signal transduction pathways converge to the same enhancer element. Oncogene. 1988; 3:301-311. [PubMed: 2849742]

86. Luna M, Wong S, Gomer CJ. Photodynamic therapy mediated induction of early response genes. Cancer Res. 1994; 54:1374-1380. [PubMed: 8118827]

87. Kick G, Messer G, Plewig G, Kind P, Goetz AE. Strong and prolonged induction of c-jun and c-fos proto-oncogenes by photodynamic therapy. Br J Cancer. 1996; 74:30-36. [PubMed: 8679454]

88. Nakagawa H, Matsumiya T, Sakaki H, Imaizumi T, Kubota K, Kusumi A, Kobayashi W. Kimura Expression of vascular endothelial growth factor by photodynamic therapy with mono-L-aspartyl chlorin e6 (NPe6) in oral squamous cell carcinoma. Oral Oncol. 2007; 43:544-550. [PubMed: 17257889]

89. Granville DJ, Carthy CM, Jiang H, Levy JG, McManus BM, Matroule JY, Piette J, Hunt DW. Nuclear factor-kappaB activation by the photochemotherapeutic agent verteporfin. Blood. 2000; 95:256-262. [PubMed: 10607710]

90. Sanovic R, Krammer B, Grumboeck S, Verwanger T. Time-resolved gene expression profiling of human squamous cell carcinoma cells during the apoptosis process induced by photodynamic treatment with hypericin. Int J Oncol. 2009; 35:921-939. [PubMed: 19724930]

91. Verwanger T, Sanovic R, Aberger F, Frischauf AM, Krammer B. Gene expression pattern following photodynamic treatment of the carcinoma cell line A-431 analysed by cDNA arrays. Int J Oncol. 2002; 21:1353-1359. [PubMed: 12429988]

92. Wild PJ, Krieg RC, Seidl J, Stoehr R, Reher K, Hofmann C, Louhelainen J, Rosenthal A, Hartmann A, Pilarsky C, Bosserhoff AK, Knuechel R. RNA expression profiling of normal and tumor cells following photodynamic therapy with 5-aminolevulinic acid-induced protoporphyrin IXin vitro. Mol Cancer Ther. 2005; 4:516-528. [PubMed: 15827324]

93. Rasch MH, Tijssen K, Lagerberg JW, Corver WE, VanSteveninck J, Dubbelman TM. The role of protein kinase $\mathrm{C}$ activity in the killing of Chinese hamster ovary cells by ionizing radiation and photodynamic treatment. Photochem Photobiol. 1997; 66:209-213. [PubMed: 9277139]

94. Xue LY, Qiu Y, He J, Kung HJ, Oleinick NL. Etk/Bmx, a PH-domain-containing tyrosine kinase, protects prostate cancer cells from apoptosis induced by photodynamic therapy or thapsigargin. Oncogene. 1999; 18:3391-3398. [PubMed: 10362360]

95. Zhuang S, Kochevar IE. Singlet oxygen-induced activation of Akt/protein kinase B is independent of growth factor receptors. Photochem Photobiol. 2003; 78:361-371. [PubMed: 14626664]

96. Espada J, Galaz S, Sanz-Rodríguez F, Blázquez-Castro A, Stockert JC, Bagazgoitia L, Jaén P, González S, Cano A, Juarranz A. Oncogenic H-Ras and PI3K signaling can inhibit E-cadherindependent apoptosis and promote cell survival after photodynamic therapy in mouse keratinocytes. J Cell Physiol. 2009; 219:4-93.

97. Kocanova S, Buytaert E, Matroule JY, Piette J, Golab J, de Witte P, Agostinis P. Induction of heme-oxygenase 1 requires the p38MAPK and PI3K pathways and suppresses apoptotic cell death following hypericin-mediated photodynamic therapy. Apoptosis. 2007; 12:731-741. [PubMed: 17219054] 
98. Tong Z, Singh G, Rainbow AJ. Sustained activation of the extracellular signal-regulated kinase pathway protects cells from photofrin-mediated photodynamic therapy. Cancer Res. 2002; 62:5528-5535. [PubMed: 12359764]

99. Buytaert E, Matroule JY, Durinck S, Close P, Kocanova S, Vandenheede JR, de Witte PA, Piette J, Agostinis P. Molecular effectors and modulators of hypericin-mediated cell death in bladder cancer cells. Oncogene. 2008; 27:1916-1929. [PubMed: 17952126]

100. Keyse SM, Emslie EA. Oxidative stress and heat shock induce a human gene encoding a proteintyrosine phosphatase. Nature. 1992; 359:644-647. [PubMed: 1406996]

101. Li J, Gorospe M, Hutter D, Barnes J, Keyse SM, Liu Y. Transcriptional induction of MKP-1 in response to stress is associated with histone $\mathrm{H} 3$ phosphorylation-acetylation. Mol Cell Biol. 2001; 21:8213-8224. [PubMed: 11689710]

102. Barbacid M. ras genes. Annu Rev Biochem. 1987; 56:779-827. [PubMed: 3304147]

103. Downward J. Targeting RAS signalling pathways in cancer therapy. Nat Rev Cancer. 2003; 3:1122. [PubMed: 12509763]

104. Santibanez JF, Hurtado C. Ha-Ras sensitizes transformed mouse skin cells to anisomycin-induced apoptosis. FEBS Lett. 2005; 579:6459-6464. [PubMed: 16288745]

105. Wakabayashi Y, Mao JH, Brown K, Girardi M, Balmain A. Promotion of Hras-induced squamous carcinomas by a polymorphic variant of the Patched gene in FVB mice. Nature. 2007; 445:761765. [PubMed: 17230190]

106. Rodriguez L, Di Venosa G, Batlle A, Macrobert A, Casas A. Response to ALA-based PDT in an immortalised normal breast cell line and its counterpart transformed with the Ras oncogene. Photochem Photobiol Sci. 2007; 6:1306-1310. [PubMed: 18046486]

107. Rodriguez L, Di Venosa G, Schickinger S, Batlle A, MacRobert A, Casas A. Resistencia a la Terapia Fotodinámica en células transfectadas con el oncogen H-ras. Medicina (B Aires). 2007; 67:79.

108. Oleinick NL, Morris RL, Belichenko I. The role of apoptosis in response to photodynamic therapy: what, where, why, and how. Photochem Photobiol Sci. 2002; 1:1-21. [PubMed: 12659143]

109. Reiners JJ Jr, Agostinis P, Berg K, Oleinick NL, Kessel D. Assessing autophagy in the context of photodynamic therapy. Autophagy. 2010; 6:7-18. [PubMed: 19855190]

110. Kessel D. Relocalization of cationic porphyrins during photodynamic therapy. Photochem Photobiol Sci. 2002; 1:837-840. [PubMed: 12659521]

111. Kessel D, Luo Y, Deng Y, Chang CK. The role of subcellular localization in initiation of apoptosis by photodynamic therapy. Photochem Photobiol. 1997; 65:422-426. [PubMed: 9077123]

112. Dellinger M. Apoptosis or necrosis following Photofrin photosensitization: influence of the incubation protocol. Photochem Phorobiol. 1996; 64:182-187.

113. Kessel D, Castelli M. Evidence that Bcl-2 is the target of three photosensitizers that induce a rapid apoptotic response. Photochem Photobiol. 2001; 74:318-322. [PubMed: 11547571]

114. Kessel D, Luguya R, Vicente MG. Localization and photodynamic efficacy of two cationic porphyrins varying in charge distribution. Photochem Photobiol. 2003; 78:431-435. [PubMed: 14653572]

115. Kessel D, Luo Y, Mathieu P, Reiners JJ Jr. Determinants of the apoptotic response to lysosomal photodamage. Photochem Photobiol. 2000; 71:196-200. [PubMed: 10687394]

116. Kessel D, Oleinick NL. Initiation of autophagy by photodynamic therapy. Methods Enzymol. 2009; 453:1-16. [PubMed: 19216899]

117. Kessel D, Arroyo AS. Apoptotic and autophagic responses to Bcl-2 inhibition and photodamage. Photochem Photobiol Sci. 2007; 6:1290-1295. [PubMed: 18046484]

118. Kessel D, Oleinick NL. Photodynamic therapy and cell death pathways. Methods Mol Biol. 2010; 635:35-46. [PubMed: 20552338]

119. Almeida RD, Manadas BJ, Carvalho AP, Duarte CB. Intracellular signaling mechanisms in photodynamic therapy. Biochim Biophys Acta. 2004; 1704:59-86. [PubMed: 15363861] 
120. Granville DJ, Carthy CM, Jiang H, Shore GC, McManus BM, Hunt DW. Rapid cytochrome c release, activation of caspases 3: 6: 7 and 8 followed by Bap31 cleavage in HeLa cells treated with photodynamic therapy. FEBS Lett. 1998; 437:5-10. [PubMed: 9804161]

121. Reed JC. Bcl-2 family proteins. Oncogene. 1998; 17:3225-3236. [PubMed: 9916985]

122. Gross A, McDonnell JM, Korsmeyer SJ. BCL-2 family members and the mitochondria in apoptosis. Genes. 1999; 13:1899-1911.

123. Granville DJ, Jiang H, An MT, Levy JG, McManus BM, Hunt DW. Bcl-2 overexpression blocks caspase activation and downstream apoptotic events instigated by photodynamic therapy. $\mathrm{Br} \mathbf{J}$ Cancer. 1999; 79:95-100. [PubMed: 10408699]

124. Srivastava M, Ahmad H, Gupta S, Mukhtar H. Involvement of Bcl-2 and Bax in photodynamic therapy mediated apoptosis. J Biol Chem. 2001; 276:15481-15488. [PubMed: 11278320]

125. Zacal N, Espiritu M, Singh G, Rainbow AJ. Increased BNip3 and decreased mutant p53 in cisplatin-sensitive PDT-resistant HT29 cells. Biochem Biophys Res Commun. 2005; 331:648657. [PubMed: 15850808]

126. He J, Agarwal M, Larkin H, Friedman L, Xue L, Oleinick N. The induction of partial resistance to photodynamic therapy by the protooncogene BCL-2. Photochem Photobiol. 1996; 64:845852. [PubMed: 8931384]

127. Kim H, Luo Y, Li G, Kessel D. Enhanced apoptotic response to photodynamic therapy after bcl-2 transfection. Cancer res. 1999; 59:3429-3432. [PubMed: 10416606]

128. Zhang WG, Ma LP, Wang SW, Zhang ZY, Cao GD. Antisense bcl-2 retrovirus vector increases the sensitivity of a human gastric adenocarcinoma cell line to photodynamic therapy. Photochem Photobiol. 1999; 69:582-586. [PubMed: 10333765]

129. Kawaguchi T, Yamamoto S, Naka N, Okishio K, Atagi S, Ogawara M, Hosoe S, Kawahara M, Furuse K. Immunohistochemical analysis of Bcl-2 protein in early squamous cell carcinoma of the bronchus treated with photodynamic therapy. Br J Cancer. 2000; 82:418-423. [PubMed: 10646898]

130. McGarrity TJ, Peiffer LP, Granville DJ, Carthy CM, Levy JG, Khandelwal M, Hunt DW. Apoptosis associated with esophageal adenocarcinoma: influence of photodynamic therapy. Cancer Lett. 2001; 163:33-41. [PubMed: 11163106]

131. Koukourakis M, Corti L, Skarlatos J, Giatromanolaki A, Krammer B, Blandamura S, Piazza M, Verwanger T, Schnitzhofer G, Kostandelos J, Beroukas K. Clinical and experimental evidence of Bcl-2 involvement in the response to photodynamic therapy. Antinacer Res. 2001; 21:663-668.

132. Xue LY, Chiu SM, Oleinick NL. Photochemical destruction of the Bcl-2 oncoprotein during photodynamic therapy with the phthalocyanine photosensitizer Pc 4. Oncogene. 2001; 20:3420 3427. [PubMed: 11423992]

133. Usuda J, Azizuddin K, Chiu SM, Oleinick NL. Association between the photodynamic loss of Bcl-2 and the sensitivity to apoptosis caused by phthalocyanine photodynamic therapy. Photochem Photobiol. 2003; 78:1-8. [PubMed: 12929741]

134. Chiu SM, Xue LY, Usuda J, Azizuddin K, Oleinick NL. Bax is essential for mitochondrionmediated apoptosis but not for cell death caused by photodynamic therapy. Br J Cancer. 2003; 89:1590-1597. [PubMed: 14562036]

135. Usuda J, Hirata T, Ichinose S, Ishizumi T, Inoue T, Ohtani K, Maehara S, Yamada M, Tsutsui H, Okunaka T, Kato H, Ikeda N. Tailor-made approach to photodynamic therapy in the treatment of cancer based on Bcl-2 photodamage. Int J Oncol. 2008; 33:689-696. [PubMed: 18813781]

136. Wan Q, Liu L, Xing D, Chen Q. Bid is required in NPe6-PDT-induced apoptosis. Photochem Photobiol. 2008; 84:250-257. [PubMed: 18173728]

137. Ichinose S, Usuda J, Hirata T, Inoue T, Ohtani K, Maehara S, Kubota M, Imai K, Tsunoda Y, Kuroiwa Y, Yamada K, Tsutsui H, Furukawa K, Okunaka T, Oleinick NL, Kato H. Lysosomal cathepsin initiates apoptosis, which is regulated by photodamage to $\mathrm{Bcl}-2$ at mitochondria in photodynamic therapy using a novel photosensitizer, ATX-s10 (Na). Int J Oncol. 2006; 29:349355. [PubMed: 16820876]

138. Caruso JA, Mathieu PA, Joiakim A, Leeson B, Kessel D, Sloane BF, Reiners JJ Jr. Differential susceptibilities of murine hepatoma 1c1c7 and Tao cells to the lysosomal photosensitizer NPe6: 
influence of aryl hydrocarbon receptor on lysosomal fragility and protease contents. Mol Pharmacol. 2004; 4:1016-1028. [PubMed: 15044632]

139. Shaw P, Bovey R, Tardy S, Sahli R, Sordat B, Costa J. Induction of apoptosis by wild-type p53 in a human colon tumor-derived cell line. Proc Natl Acad Sci USA. 1992; 89:4495-4499. [PubMed: 1584781]

140. Siognov RV, Haupt Y. The cellular response to p53: the decision between life and death. Oncogene. 1999; 18:6145-6157. [PubMed: 10557106]

141. Fisher AMR, Danenberg K, Banerjee D, Bertino JR, Danenberg P, Gomer CJ. Increased photosensitivity in HL60 cells expressing wild-type p53. Photochem Photobiol. 1997; 66:265270. [PubMed: 9277147]

142. Fisher AM, Rucker N, Wong S, Gomer CJ. Differential photosensitivity in wild-type and mutant p53 human colon carcinoma cell lines. J Photochem Photobiol. 1998; 42:104-107.

143. Tong Z, Singh G, Rainbow AJ. The role of the p53 tumor suppressor in the response of human cells to photofrin-mediated photodynamic therapy. Photochem Photobiol. 2000; 71:201-210. [PubMed: 10687395]

144. Fisher AMR, Ferrario A, Rucker N, Zhang S, Gomer CJ. Photodynamic therapy sensitivity is not altered in human tumor cells after abrogation of p53 function. Cancer Res. 1999; 59:331-335. [PubMed: 9927042]

145. Zawacka-Pankau J, Krachulec J, Grulkowski I, Bielawski KP, Selivanova G. The p53-mediated cytotoxicity of photodynamic therapy of cancer: recent advances. Toxicol Appl Pharmacol. 2008; 232:487-497. [PubMed: 18721824]

146. Xue LY, Chiu SM, Oleinick NL. Atg7 deficiency increases resistance of MCF-7 human breast cancer cells to photodynamic therapy. Autophagy. 2010; 6:248-255. [PubMed: 20083906]

147. Kessel D, Reiners JJ Jr. Apoptosis and autophagy after mitochondrial or endoplasmic reticulum photodamage. Photochem Photobiol. 2007; 83:1024-1028. [PubMed: 17880495]

148. Dewaele M, Martinet W, Rubio N, Verfaillie T, de Witte PA, Piette J, Agostinis P. Autophagy pathways activated in response to PDT contribute to cell resistance against ROS damage. J Cell Mol Med. 2010 [In press].

149. Davids LM, Kleemann B, Cooper S, Kidson SH. Melanomas display increased cytoprotection to hypericin-mediated cytotoxicity through the induction of autophagy. Cell Biol Int. 2009; 33:1065-1072. [PubMed: 19596456]

150. Grune T, Merker K, Sandig G, Davies KJ. Selective degradation of oxidatively modified protein substrates by the proteasome. Biochem Biophys Res Commun. 2003; 305:709-718. [PubMed: 12763051]

151. Dunlop RA, Rodgers KJ, Dean RT. Recent developments in the intracellular degradation of oxidized proteins. Free Radic Biol Med. 2002; 33:894-906. [PubMed: 12361801]

152. Lee AH, Iwakoshi NN, Anderson KC, Glimcher LH. Proteasome inhibitors disrupt the unfolded protein response in myeloma cells. Proc Natl Acad Sci USA. 2003; 100:9946-9951. [PubMed: 12902539]

153. Szokalska A, Makowski M, Nowis D, Wilczynski GM, Kujawa M, Wójcik C, Mlynarczuk-Bialy I, Salwa P, Bil J, Janowska S, Agostinis P, Verfaillie T, Bugajski M, Gietka J, Issat T, Glodkowska E, Mrówka P, Stoklosa T, Hamblin MR, Mróz P, Jakóbisiak M, Golab J. Proteasome inhibition potentiates antitumor effects of photodynamic therapy in mice through induction of endoplasmic reticulum stress and unfolded protein response. Cancer Res. 2009; 69:4235-4243. [PubMed: 19435917]

154. Carracedo A, Geelen MJ, Diez M, Hanada K, Guzman M, Velasco G. Ceramide sensitizes astrocytes to oxidative stress: protective role of cannabinoids. Biochem J. 2004; 380:435-440. [PubMed: 14979873]

155. Wispriyono B, Schmelz E, Pelayo H, Hanada K, Separovic D. A role for the de novo sphingolipids in apoptosis of photosensitized cells. Exp Cell Res. 2002; 279:153-165. [PubMed: 12213223]

156. Separovic D, Semaan L, Tarca AL, Awad Maitah MY, Hanada K, Bielawski J, Villani M, Luberto C. Suppression of sphingomyelin synthase 1 by small interference RNA is associated 
with enhanced ceramide production and apoptosis after photodamage. Exp Cell Res. 2008; 314:1860-1868. [PubMed: 18374917]

157. Burow ME, Weldon CB, Melnik LI, Duong BN, Collins-Burow BM, Beckman BS, McLachlan JA. PI3-K/KT regulation of NF-kappaB signaling events in suppression of TNF-induced apoptosis. Biochem Biophys Res Commun. 2000; 271:342-334. [PubMed: 10799299]

158. Krebs J. The role of calcium in apoptosis. Biometals. 1998; 11:375-382. [PubMed: 10191500]

159. Levy-Strumpf N, Kimchi A. Death associated proteins (DAPs): from gene identification to the analysis of their apoptotic and tumor suppressive functions. Oncogene. 1998; 17:3331-3340. [PubMed: 9916995]

160. Rodriguez-Mora OG, Lahair MM, Evans MJ, Kovacs CJ, Allison RR, Sibata CH, White KS, McCubrey JA, Franklin RA. Inhibition of the CaM-kinases augments cell death in response to oxygen radicals and oxygen radical inducing cancer therapies in MCF-7 human breast cancer cells. Cancer Biol Ther. 2006; 5:1022-1030. [PubMed: 16855386]

161. Kliukiene R, Maroziene A, Nivinskas H, Cenas N, Kirveliene V, Juodka B. Biochem Mol Biol Int. 1997; 41:707-713. [PubMed: 9111932]

162. Golab J, Nowis D, Skrzycki M, Czeczot H, Baranczyk-Kuzma A, Wilczynski GM, Makowski M, Mroz P, Kozar K, Kaminski R, Jalili A, Kopec' M, Grzela T, Jakobisiak M. Antitumor effects of photodynamic therapy are potentiated by 2 -methoxyestradiol. A superoxide dismutase inhibitor. $\mathrm{J}$ Biol Chem. 2003; 278:407-414. [PubMed: 12409296]

163. Dolgachev V, Oberley LW, Huang TT, Kraniak JM, Tainsky MA, Hanada K, Separovic D. A role for manganese superoxide dismutase in apoptosis after photosensitization. Biochem Biophys Res Commun. 2005; 332:411-417. [PubMed: 15894290]

164. Oberdanner CB, Plaetzer K, Kiesslich T, Krammer B. Photodynamic treatment with fractionated light decreases production of reactive oxygen species and cytotoxicity in vitro via regeneration of glutathione. Photochem Photobiol. 2005; 81:609-613. [PubMed: 15686441]

165. Wang H, Qian S, Schafer F, Domann F, Oberley L, Buettner G. Phospholipid hydroperoxide glutathione peroxidase protects against singlet oxygen-induced cell damage of photodynamic therapy. Free Radic Biol Med. 2001; 30:825-835. [PubMed: 11295525]

166. Dabrowski MJ, Maeda D, Zebala J, Lu WD, Mahajan S, Kavanagh TJ, Atkins WM. Glutathione S-transferase P1-1 expression modulates sensitivity of human kidney 293 cells to photodynamic therapy with hypericin. Arch Biochem Biophys. 2006; 449:94-103. [PubMed: 16546115]

167. Borst P, Evers R, Kool M, Wijnholds J. A family of drug transporters: the multidrug resistanceassociated proteins. J Natl Cancer Inst. 2000; 92:1295-1302. [PubMed: 10944550]

168. Schlesinger M. Heat shock proteins. J Biol Chem. 1990; 265:12111-12114. [PubMed: 2197269]

169. Gomer CJ, Luna M, Ferrario A, Rucker N. Increased transcription and translation of heme oxygenase in Chinese hamster fibroblasts following photodynamic stress or Photofrin II incubation. Photochem Photobiol. 1991; 53:275-279. [PubMed: 1826371]

170. Curry PM, Levy JG. Stress protein expression in murine tumor cells following photodynamic therapy with benzoporphyrin derivative. Photochem Photobiol. 1993; 58:374-379. [PubMed: 8234472]

171. Gomer CJ, Ferrario A, Rucker N, Wong S, Lee AS. Glucose regulated protein induction and cellular resistance to oxidative stress mediated by porphyrin photosensitization. Cancer Res. 1991; 51:6574-6579. [PubMed: 1835901]

172. Jozkowicz A, Was H, Dulak J. Heme oxygenase-1 in tumors: is it a false friend? Antioxid Redox Signal. 2007; 9:2099-2117. [PubMed: 17822372]

173. Gomer C, Rucker N, Wong S. Porphyrin photosensitivity in cell lines expressing a heat-resistant phenotype. Cancer Res. 1990; 50:5365-5368. [PubMed: 2143688]

174. Hanlon J, Adams K, Rainbow A, Gupta R, Singh G. Induction of HSP60 by Photofrin-mediated photodynamic therapy. J Photochem Photobiol. 2001; 64:55-61.

175. Wang H, Hanlon J, Rainbow A, Espiritu M, Singh G. Up-regulation of HSP27 plays a role in the resistance of human colon carcinoma HT29 cells to photooxidative stress. Photochem Photobiol. 2002; 76:98-104. [PubMed: 12126313] 
176. Xue LY, He J, Oleinick NL. Rapid tyrosine phosphorylation of HS1 in the response of mouse lymphoma L5178Y-R cells to photodynamic treatment sensitized by the phthalocyanine Pc 4 . Photochem Photobiol. 1997; 66:105-113. [PubMed: 9230709]

177. Nowis D, Legat M, Grzela T, Niderla J, Wilczek E, Wilczynski GM, Głodkowska E, Mrówka P, Issat T, Dulak J, Józkowicz A, Waś H, Adamek M, Wrzosek A, Nazarewski S, Makowski M, Stokłosa T, Jakóbisiak M, Gołab J. Heme oxygenase-1 protects tumor cells against photodynamic therapy-mediated cytotoxicity. Oncogene. 2006; 25:3365-3374. [PubMed: 16462769]

178. Järveläinen H, Sainio A, Koulu M, Wight TN, Penttinen R. Extracellular matrix molecules: potential targets in pharmacotherapy. Pharmacol Rev. 2009; 61:198-223. [PubMed: 19549927]

179. Askari JA, Buckley PA, Mould AP, Humphries MJ. Linking integrin conformation to function. J Cell Sci. 2009; 122:165-170. [PubMed: 19118208]

180. Cianfriglia M, Yassen A, Tombesi M, Samoggia P, Barca S, Caserta M. Expression of lymphocyte homing receptor gene is lost in multi-drug-resistant variant of human lymphoblastoid CCRF-CEM cells. Int J Cancer. 1991; 49:394-397. [PubMed: 1917137]

181. Thompson E, Paik S, Brunner N, Sommers C, Zugmaier G, Clarke R, Shima T, Torri J, Donhaue S, Lippman M, Martin G, Dickson R. Association of increased basement membrane invasiveness with absence of estrogen receptor and expression of vimentin in human breast cancer cell lines. $\mathrm{J}$ Cell Physiol. 1992; 150:534-544. [PubMed: 1537883]

182. Hazlehurst LA, Dalton WS. Mechanisms associated with cell adhesion mediated drug resistance (CAM-DR) in hematopoietic malignancies. Cancer Metastasis Rev. 2001; 20:43-50. [PubMed: 11831646]

183. Cordes N, Meineke V. Cell adhesion-mediated radioresistance (CAM-RR): extracellular matrixdependent improvement of cell survival in human tumor and normal cells in vitro. Strahlenther Onkol. 2003; 179:337-344. [PubMed: 12740661]

184. Cordes N. Overexpression of hyperactive integrin-linked kinase leads to increased cellular radiosensitivity. Cancer Res. 2004; 64:5683-5692. [PubMed: 15313908]

185. Margaron P, Sorrenti R, Levy JG. Photodynamic therapy inhibits cell adhesion without altering integrin expression. Biochim Biophys Acta. 1997; 1359:200-210. [PubMed: 9434126]

186. Runnels JM, Chen N, Ortel B, Kato D, Hasan T. BPD-MA mediated photosensitization in vitro and in vivo: cellular adhesion and beta1 integrin expression in ovarian cancer cells. Br J Cancer. 1999; 80:946-953. [PubMed: 10362101]

187. Rousset N, Vonarx V, Eleouet S, Carre J, Kerninon E, Lajat Y, Patrice T. Effects of photodynamic therapy on adhesion molecules and metastasis. J Photochem Photobiol B. 1999; 52:65-73. [PubMed: 10643074]

188. Momma T, Hamblin MR, Wu HC, Hasan T. Photodynamic therapy of orthotopic prostate cancer with benzoporphyrin derivative: local control and distant metastasis. Cancer Res. 1998; 58:54255431. [PubMed: 9850075]

189. Casas A, Di Venosa G, Vanzulli S, Perotti C, Mamome L, Rodriguez L, Simian M, Juarranz A, Pontiggia O, Hasan T, Batlle A. Decreased metastatic phenotype in cells resistant to aminolevulinic acid-photodynamic therapy. Cancer Lett. 2008; 271:342-351. [PubMed: 18662847]

190. Foultier M, Vonarx-Coinsmann V, Cordel S, Combre A, Patrice T. Modulation of colonic cancer cell adhesiveness by haematoporphyrin derivative photodynamic therapy. J Photochem Photobiol. 1994; 23:9-17.

191. Vonarx V, Foultier M, de Brito X, Anasagasti L, Morlet L, Patrice T. Photodynamic therapy decreases cancer colonic cell adhesiveness and metastatic potential. Res Exp Med. 1995; 195:101-116.

192. Overhaus M, Heckenkamp J, Kossodo S, Leszcynski D, La Muraglia G. Photodynamic therapy generates a matrix barrier to invasive vascular cell migration. Circ Res. 2000; 86:334-340. [PubMed: 10679486]

193. Lee C, Wu S, Chen L. Photosensitization by 3,3'-dihexyloxacarbocyanine iodide: specific disruption of microtubules and inactivation of organelle motility. Cancer Res. 1995; 55:20632069. [PubMed: 7743503] 
194. Lambrechts A, Troys M, Ampe C. The actin cytoskeleton in normal and pathological cell motility. Int J Biochem Cell Biol. 2004; 36:1890-1909. [PubMed: 15203104]

195. Ruoslahti E. Fibronectin and its integrin receptors in cancer (Review). Adv Cancer Res. 1999; 76:1-20. [PubMed: 10218097]

196. Galaz S, Espada J, Stockert JC, Pacheco M, Sanz-Rodriguez F, Arranz R, Rello S, Canete M, Villanueva A, Esteller M, Juarranz A. Loss of E-cadherin mediated cell-cell adhesion as an early trigger of apoptosis induced by photodynamic treatment. J Cell Physiol. 2005; 205:86-96. [PubMed: 15880654]

197. Casas A, Sanz-Rodriguez F, Di Venosa G, Rodriguez L, Mamone L, Blázquez A, Jaén P, Batlle A, Stockert JC, Juarranz A. Disorganisation of cytoskeleton in cells resistant to photodynamic treatment with decreased metastatic phenotype. Cancer Lett. 2008; 270:56-65. [PubMed: 18513853]

198. Giese G, Schmidt J, Gilbert M, Albrecht R, Traub P. TPA induces apoptosis in MPC-11 mouse plasmacytoma cells grown in serum-free medium. Biol Cell. 1997; 89:99-111. [PubMed: 9351190]

199. Hashimoto M, Inoue S, Ogawa S, Conrad C, Muramatsu M, Shackelford D, Maliah E. Rapid fragmentation of vimentin in human skin fibroblasts exposed to tamoxifen: a possible involvement of caspase-3. Biochem Biophys Res Commun. 1998; 247:401-406. [PubMed: 9642140]

200. Belichenko I, Morishima N, Separovic D. Caspase-resistant vimentin suppressed apoptosis after photodynamic treatment with a silicon phthalocyanine in Jurkat cells. Arch Biochem Biophys. 2001; 390:57-63. [PubMed: 11368515]

201. Perry R, Matthews W, Mitchell J, Russo A, Evans S, Pass H. Sensitivity of different human lung cancer histologies to Photodynamic Therapy. Cancer Res. 1990; 50:4272-4276. [PubMed: 2142015]

202. Dodson JW, Hay ED. Secretion of Collagen by Corneal Epithelium. II. Effect of the Underlying Substratum on Secretion and Polymerisational Epithelial Cell Products. J Exptl Zool. 1974; 789:51-72. [PubMed: 4209943]

203. Gospodarowicz D, Greenburg G, Birdwell CR. Determination of cellular shape by the extracellular matrix and its correlation with the control of cellular growth. Cancer Res. 1978; 38:4155-4171. [PubMed: 359133]

204. Brambilla E, Moro D, Gazzeri S, Brichon P, Nagy-Mignotte H, Morel F, Jacrot M, Brambilla C. Cytotoxic chemotherapy induces cell differentiation in small-cell lung carcinoma. J Clin Oncol. 1991; 9:50-61. [PubMed: 1702146]

205. Richter A, Kelly B, Chow J, Liu D, Towers G, Dolphin D, Levy J. Preliminary studies on a more effective phototoxic agent than hematoporphyrin. J Natl Cancer Inst. 1987; 79:1327-1332. [PubMed: 3480384]

206. Girotti A. Photodynamic lipid peroxidation in biological systems. Photochem Photobiol. 1990; 51:497-509. [PubMed: 2188273]

207. Smith WL, De Witt DL, Garavito RM. Cyclooxygenases: structural, cellular, and molecular biology. Annu Rev Biochem. 2000; 69:145-182. [PubMed: 10966456]

208. Williams CS, Mann M, DuBois RN. The role of cyclooxygenases in inflammation, cancer, and development. Oncogene. 1999; 18:7908-7916. [PubMed: 10630643]

209. Cao Y, Prescott SM. Many actions of cyclooxygenase-2 in cellular dynamics and in cancer. J Cell Physiol. 2002; 190:279-286. [PubMed: 11857443]

210. Liao Z, Mason KA, Milas L. Cyclo-oxygenase-2 and its inhibition in cancer: is there a role? Drugs. 2007; 67:821-845. [PubMed: 17428102]

211. Ferrario A, Von Tiehl K, Wong S, Luna M, Gomer CJ. Cyclooxygenase-2 inhibitor treatment enhances photodynamic therapy-mediated tumor response. Cancer Res. 2002; 62:3956-3961. [PubMed: 12124326]

212. Hendrickx N, Volanti C, Moens U, Seternes OM, de Witte P, Vandenheede JR, Piette J, Agostinis P. Up-regulation of cyclooxygenase-2 and apoptosis resistance by p38 MAPK in hypericinmediated photodynamic therapy of human cancer cells. J Biol Chem. 2003; 278:52231-52239. [PubMed: 14557269] 
213. Henderson BW, Donovan JM. Release of prostaglandin E2 from cells by photodynamic treatment in vitro. Cancer Res. 1989; 49:6896-6900. [PubMed: 2531034]

214. Penning LC, Keirse MJ, Van Steveninck J, Dubbelman TM. Ca(2+)-mediated prostaglandin E2 induction reduces haematoporphyrin-derivative-induced cytotoxicity of T24 human bladder transitional carcinoma cells in vitro. Biochem J. 1993; 292(Pt 1):237-240. [PubMed: 8503851]

215. Hendrickx N, Dewaele M, Buytaert E, Marsboom G, Janssens S, Van Boven M, Vandenheede JR, de Witte P, Agostinis P. Targeted inhibition of p38alpha MAPK suppresses tumor-associated endothelial cell migration in response to hypericin-based photodynamic therapy. Biochem Biophys Res Commun. 2005; 337:928-935. [PubMed: 16214108]

216. Kleban J, Mikes J, Szilárdiová B, Koval J, Sacková V, Solár P, Horváth V, Hofmanová J, Kozubík A, Fedorocko P. Modulation of hypericin photodynamic therapy by pretreatment with 12 various inhibitors of arachidonic acid metabolism in colon adenocarcinoma HT-29 cells. Photochem Photobiol. 2007; 83:1174-1185. [PubMed: 17880512]

217. Makowski M, Grzela T, Niderla J, ŁAzarczyk M, Mróz P, Kopeé M, Legat M, Strusińska K, Koziak K, Nowis D, Mrówka P, Wasik M, Jakóbisiak M, Gołab J. Inhibition of cyclooxygenase-2 indirectly potentiates antitumor effects of photodynamic therapy in mice. Clin Cancer Res. 2003; 9:5417-5422. [PubMed: 14614028]

218. Foultier MT, Patrice T, Yactayo S, Lajat Y, Resche F. Photodynamic treatment of normal endothelial cells or glioma cells in vitro. Surg Neurol. 1992; 37:83-88. [PubMed: 1546381]

219. Esteban FJ, Horcajadas A, El-Rubaidi O, Luque-Barona R, Ibáñez G, García-Carriazo A, Segovia M, del Moral-Leal ML. Nitric oxide in malignant astrocytes. Rev Neurol. 2005; 40:437-440. [PubMed: 15849679]

220. Porro A, Chrochemore C, Cambuli F, Iraci N, Contestabile A, Perini G. Nitric oxide control of MYCN expression and multi drug resistance genes in tumours of neural origin. Curr Pharm Des. 2010; 16:431-439. [PubMed: 20236072]

221. Fetz V, Bier C, Habtemichael N, Schuon R, Schweitzer A, Kunkel M, Engels K, Kovács AF, Schneider S, Mann W, Stauber RH, Knauer SK. Inducible NO synthase confers chemoresistance in head and neck cancer by modulating survivin. Int J Cancer. 2009; 124:2033-2041. [PubMed: 19130609]

222. Leung EL, Fraser M, Fiscus RR, Tsang BK. Cisplatin alters nitric oxide synthase levels in human ovarian cancer cells: involvement in p53 regulation and cisplatin resistance. Br J Cancer. 2008; 98:1803-1809. [PubMed: 18506185]

223. Rubbo H, Radi R, Trujillo M, Kalyanaraman B, Barnes S, Freeman BA. Nitric oxide regulation of superoxide and peroxynitrite-dependent lipid peroxidation. J Biol Chem. 1994; 269:2606626075. [PubMed: 7929318]

224. Niziolek M, Korytowski W, Girotti AW. Chain-breaking antioxidant and cytoprotective action of nitric oxide on photodynamically stressed tumor cells. Photochem Photobiol. 2003; 78:262-270. [PubMed: 14556313]

225. Kim YM, Bergonia H, Lancaster JR. Nitric oxide-induced autoprotection of isolated rat hepatocytes. FEBS Lett. 1995; 374:228-232. [PubMed: 7589541]

226. Joshi MS, Ponthier JL, Lancaster JR. Cellular antioxidant and prooxidant actions of nitric oxide. Free Radic Biol Med. 1999; 27:1357-1366. [PubMed: 10641730]

227. Niziolek-Kierecka M, Pilat A, Korytowski W, Girotti AW. Apoptosis-accommodating effect of nitric oxide in photodynamically stressed tumor cells. Photochem Photobiol. 2010; 86:681-686. [PubMed: 20331521]

228. Zareba M, Niziolek M, Korytowski W, Girotti AW. Merocyanine 540-sensitized photokilling of leukemia cells: role of post-irradiation chain peroxidation of plasma membrane lipids as revealed by nitric oxide protection. Biochim Biophys Acta. 2005; 1722:51-59. [PubMed: 15716134]

229. Di Venosa G, Casas A, Fukuda H, Perotti C, Batlle A. No cross-resistance between ALAmediated photodynamic therapy and nitric oxide. Nitric Oxide. 2005; 13:155-162. [PubMed: 16115785]

230. Di Venosa G, Perotti C, Fukuda H, Batlle A, Casas A. Sensitivity to ALA-PDT of cell lines with different nitric oxide production and resistance to NO cytotoxicity. J Photochem Photobiol B. 2005; 80:195-202. [PubMed: 15967676] 
231. Bhowmick R, Girotti AW. Cytoprotective Induction of Nitric Oxide Synthase in a Cellular Model of 5-Aminolevulinic Acid-Based Photodynamic Therapy. Free Radic Biol Med. 2010; 48:12961301. [PubMed: 20138143]

232. Mita AC, Mita MM, Nawrocki ST, Giles FJ. Survivin: key regulator of mitosis and apoptosis and novel target for cancer therapeutics. Clin Cancer Res. 2008; 14:5000-5005. [PubMed: 18698017]

233. Altieri DC. Validating survivin as a cancer therapeutic agent. Nat Rev Cancer. 2003; 3:46-54. [PubMed: 12509766]

234. Zhen HN, Zhang X, Hu PZ. Survivin expression and its relation with proliferation, apoptosis, and angiogenesis in brain gliomas. Cancer. 2005; 104:2775-2783. [PubMed: 16284993]

235. Fortugno P, Beltrami E, Plescia J, Fontana J, Pradhan D, Marchisio PC, Sessa WC, Altieri DC. Regulation of survivin function by HSP90. Proc Natl Acad Sci USA. 2003; 100:13791-13796. [PubMed: 14614132]

236. Ferrario A, Rucker N, Wong S, Luna M, Gomer CJ. Survivin, a member of the inhibitor of apoptosis family, is induced by photodynamic therapy and is a target for improving treatment response. Cancer Res. 2007; 67:4989-4995. [PubMed: 17510430]

237. He GF, Bian ML, Zhao YW, Xiang Q, Li HY, Xiao C. A study on the mechanism of 5aminolevulinic acid photodynamic therapy in vitro and in vivo in cervical cancer. Oncol Rep. 2009; 21:861-868. [PubMed: 19287980]

238. He GF, Bian ML, Zhao YW, Xiang Q, Li HY, Xiao C. Apoptosis-inducing effect of 5aminolevulinic acid-mediated photodynamic therapy (5-ALA-PDT) on cervical cancer cell lines. Ai Zheng. 2008; 27:897-904. [PubMed: 18799024]

239. Ferrario A, Gomer CJ. Targeting the $90 \mathrm{kDa}$ heat shock protein improves photodynamic therapy. Cancer Lett. 2010; 289:188-194. [PubMed: 19733005]

240. Vaupel P, Harrison L. Tumor hypoxia: causative factors, compensatory mechanisms, and cellular response. Oncologist. 2004; 9(Suppl 5):4-9. [PubMed: 15591417]

241. Ferrario A, von Tiehl KF, Rucker N, Schwarz MA, Gill PS, Gomer CJ. Antiangiogenic treatment enhances photodynamic therapy responsiveness in a mouse mammary carcinoma. Cancer Res. 2000; 60:4066-4069. [PubMed: 10945611]

242. Okunaka T, Usuda J, Ichinose S, Hirata H, Ohtani K, Maehara S, Inoue T, Imai K, Kubota M, Tsunoda Y, Kuroiwa Y, Tsutsui H, Furukawa K, Nishio K, Kato H. A possible relationship between the anti-cancer potency of photodynamic therapy using the novel photosensitizer ATX$\mathrm{s} 10-\mathrm{Na}(\mathrm{II})$ and expression of the vascular endothelial growth factor in vivo. Oncol Rep. 2007; 18:679-683. [PubMed: 17671719]

243. Reyal J. Arterial flow focalization could increase tissue oxygen partial pressure, or trigger endothelial shear stress -A new concept to overcome cancer hypoxia-induced radiotherapy resistance, or stimulate liver regeneration during fulminant hepatitis. Med Hypotheses. 2009; 74:301-308. [PubMed: 19796881]

244. Boyer M. Bioreductive agents: a clinical update. Oncol Res. 1997; 9:391-395. [PubMed: 9406245]

245. Patterson A, Williams K, Cowen R, Jaffar M, Telfer B, Saunders M, Airley R, Honess D, van der Kogel A, Wolf C, Stratford U. Oxygen-sensitive enzyme-prodrug gene therapy for the eradication of radiation-resistant solid tumours. Gene Ther. 2002; 9:946-954. [PubMed: 12085243]

246. Datta S, Allman R, Loh C, Mason M, Matthews P. Effect of photodynamic therapy in combination with mitomycin $\mathrm{C} n$ a mitomycin-resistant bladder cancer cell line. Br J Cancer. 1997; 76:312-317. [PubMed: 9252197]

247. Miyagi K, Sampson RW, Sieber-Blum M, Sieber F. Crystal violet combined with Merocyanine 540 for the ex vivo purging of hematopoietic stem cell grafts. J Photochem Photobiol B. 2003; 70:133-144. [PubMed: 12962637]

248. Nishii Y, Morishima M, Kakehi Y, Umehara K, Kioka N, Terano Y, Amachi T, Ueda K. CROP/ Luc7A, a novel serine/arginine-rich nuclear protein, isolated from cisplatin-resistant cell line. FEBS Lett. 2000; 465:153-156. [PubMed: 10631324] 
249. Lottner C, Knuechel R, Bernhardt G, Brunner H. Combined chemotherapeutic and photodynamic treatment on human bladder cells by hematoporphyrin-platinum(II) conjugates. Cancer Lett. 2004; 203:171-180. [PubMed: 14732225]

250. Fisher A, Ferrario A, Gomer C. Adriamycin resistance in chinese hamster fibroblasts following oxidative stress induced by photodynamic therapy. Photochem Photobiol. 1993; 58:581-588. [PubMed: 8248335]

251. Guo B, Hembruff SL, Villeneuve DJ, Kirwan AF, Parissenti AM. Potent killing of paclitaxel- and doxorubicin-resistant breast cancer cells by calphostin $\mathrm{C}$ accompanied by cytoplasmic vacuolization. Breast Cancer Res Treat. 2003; 82:125-141. [PubMed: 14692656]

252. Kobayashi E, Ando K, Nakano H, Iida T, Ohno H, Morimoto M, Tamaoki T. Calphostins (UCN-1028), novel and specific inhibitors of protein kinase C. I. Fermentation, isolation, physico-chemical properties and biological activities. J Antibiot (Tokyo). 1989; 42:1470-1474. [PubMed: 2478514]

253. Zacal N, Rainbow AJ. Photodynamic therapy resistant human colon carcinoma HT29 cells show cross-resistance to UVA but not UVC light. Photochem Photobiol. 2007; 83:730-737. [PubMed: 17576382]

254. Rodriguez L, Batlle A, Di Venosa G, Battah S, Dobbin P, Macrobert AJ, Casas A. Mechanisms of 5-aminolevulinic acid ester uptake in mammalian cells. Br J Pharmacol. 2006; 147:825-833. [PubMed: 16432502]

255. Correa García S, Casas A, Perotti C, Batlle A, Bermúdez Moretti M. Mechanistic studies on delta-aminolevulinic acid uptake and efflux in a mammary adenocarcinoma cell line. $\mathrm{Br} \mathrm{J}$ Cancer. 2003; 89:173-177. [PubMed: 12838320]

256. Gomer C, Rucker N, Ferrario A, Murphree A. Expression of potentially lethal damage in Chinese hamster cells exposed to hematoporphyrin derivative photodynamic therapy. Cancer Res. 1986; 46:3348-3352. [PubMed: 3011247]

257. Gerlinger M, Swanton C. How Darwinian models inform therapeutic failure initiated by clonal heterogeneity in cancer medicine. Br J Cancer. 2010; 103:1139-1143. [PubMed: 20877357]

258. Fodale V, Pierobon M, Liotta L, Petricoin E. Mechanism of cell adaptation: when and how do cancer cells develop chemoresistance? Cancer J. 2011; 17:89-95. [PubMed: 21427552]

259. Mathews LA, Cabarcas SM, Farrar WL. DNA repair: the culprit for tumor-initiating cell survival? Cancer Metastasis Rev. 2011 (in press).

260. Nahabedian M, Cohen R, Contino M, Terem T, Wright W, Berns M, Wile A. Combination cytotoxic chemotherapy with cisplatin or doxorubicin and photodynamic therapy in murine tumors. J Natl Cancer Inst. 1988; 80:739-743. [PubMed: 3385781]

261. Creekmore S, Zaharko D. Modification of chemotherapeutic effects on L1210 cells using hematoporphyrin and light. Cancer Res. 1983; 43:5252-5257. [PubMed: 6616462]

262. Casas A, Fukuda H, Riley P, Batlle A. Enhancement of aminolevulinic acid based photodynamic therapy by adriamycin. Cancer Lett. 1997; 121:105-113. [PubMed: 9459181]

263. Casas A, Fukuda H, Batlle A. Potentiation of the 5-aminolevuliniv acid-based photodynamic therapy with cyclophosphamide. Cancer Biochem Biophys. 1998; 16:183-196. [PubMed: 9923976]

264. Sato Y, Yamazaki T, Yasukawa K, Kaneita Y, Mochimaru J, Hanai M, Irie T, Kura Y, Sawada U, Horie T. Merocyanine 540-mediated photodynamic therapy inhibits P-glycoprotein (P-gp) activity in adriamycin-resistant K562 cells. Gan To Kagaku Ryoho. 1999; 26:2195-2200. [PubMed: 10635304]

265. Sinha AK, Anand S, Ortel BJ, Chang Y, Mai Z, Hasan T, Maytin EV. Methotrexate used in combination with aminolaevulinic acid for photodynamic killing of prostate cancer cells. $\mathrm{Br} \mathbf{J}$ Cancer. 2006; 95:485-495. [PubMed: 16868543]

266. Anand S, Honari G, Hasan T, Elson P, Maytin EV. Low-dose methotrexate enhances aminolevulinate-based photodynamic therapy in skin carcinoma cells in vitro and in vivo. Clin Cancer Res. 2009; 15:3333-3343. [PubMed: 19447864]

267. Kessel D. Prohing modes of multi-drug resistance via photodynamic effects of anthrapyrazoles. Anticancer Drugs. 1989; 191:223-232. 
268. Edwards B, Horn L, Twomey P. Buthionine sulfoxirnine potentiates in vitro phototoxicity in rhodamine-sensitive but not in resistant melanoma cells (Abstract). 31. Proc Am Assoc Cancer Res Annu Meet. 1990; 31:A2317.

269. Mitchell JB, Glatstein E, Cowan KH, Russo A. Photodynamic therapy of 33. multi-drug resistant cell lines. Proc Am Assoc Cancer Res Annu Meet. 1988; 29:A1254.

270. Lemoli R, Igarashi T, Knizewski M, Acaba L, Richter A, Jain A, Mitchell D, Levy J, Gulati S. Dye-mediated photolysis is capable of eliminating drug-resistant (MDR+) tumor cells. Blood. 1993; 81:793-800. [PubMed: 8427970]

271. Canti G, Lattuada D, Morelli S, Nicolin A, Cubeddu R, Taroni P, Valentini G. Efficacy of photodynamic therapy against doxorubicin-resistant murine tumors. Cancer Lett. 1995; 93:255259. [PubMed: 7621437]

272. Kusuzaki K, Minami G, Takeshita H, Murata H, Hashiguchi S, Nozaki T, Ashihara T, Hirasawa Y. Photodynamic inactivation with acridine orange on a multidrug-resistant mouse osteosarcoma cell line. Jpn J Cancer Res. 2000; 91:439-445. [PubMed: 10804293]

273. Trindade G, Farias S, Rumjanek V, Capella M. Methylene blue reverts multidrug resistance: sensitivity of multidrug resistant cells to this dye and its photodynamic action. Cancer Lett. 2000; 151:161-167. [PubMed: 10738110]

274. Gianotti, C.; Andriamanpandry, A.; Werner, GH. Studies on resistance of human cancer cells to photosensitizing phthalocyanines (Abstract). Presented at the 3rd Biennial Meeting of the International Photodynamic Association; Buffalo, NY. July, 1990;

275. Novichenko NL, Mamchur AA, Lisniak IO, Gamaliya MF. Study of photodynamic efficiency of the hematoporphyrin conjugated with antibody to VEGF in mouse Lewis carcinoma. Exp Oncol. 2008; 30:315-318. [PubMed: 19112430]

276. Khdair A, Handa H, Mao G, Panyam J. Nanoparticle-mediated combination chemotherapy and photodynamic therapy overcomes tumor drug resistance in vitro. Eur J Pharm Biopharm. 2009; 71:214-222. [PubMed: 18796331]

277. Khdair A, Di Chen, Patil Y, Ma L, Dou QP, Shekhar MP, Panyam J. Nanoparticle-mediated combination chemotherapy and photodynamic therapy overcomes tumor drug resistance. J Control Release. 2010; 141:137-144. [PubMed: 19751777]

278. Hornung R, Walt H, Crompton N, Keefe K, Jentsch B, Perewusnyk G, Haller U, Kochli O. mTHPC-mediated photodynamic therapy (PDT) does not induce resistance to chemotherapy, radiotherapy or PDT on human breast cancer cells in vitro. Photochem Photobiol. 1998; 68:569574. [PubMed: 9796440]

279. Baroja A, de la Hoz C, Alvarez A, Vielba R, Sarrat R, Arechaga J, Gandarias J. Polyploidization and exit from cell cycle as mechanisms of cultured melanoma cell resistance to methotrexate. Life Sci. 1998; 62:2275-2282. [PubMed: 9651116]

280. Brodsky, V.; Uryvaeva, I. Genome multiplication in growth and development. Cambridge University Press; Cambridge, UK: 1985. p. 205-210.

281. Tew K. Glutathione-associated enzymes in anticancer drug resistance. Cancer Res. 1994; 54:4313-4320. [PubMed: 8044778]

282. Goodwin A, Mesiter A, O'Dwyer P, Huang C, Hamilton T, Anderson M. High resistance to cisplatin in human ovarian cancer cell lines is associated with marked increase of glutathione synthesis. Proc Natl Acad Sci USA. 1992; 89:3070-3074. [PubMed: 1348364]

283. Yeung BH, Wong KY, Lin MC, Wong CK, Mashima T, Tsuruo T, Wong AS. Chemosensitisation by manganese superoxide dismutase inhibition is caspase- 9 dependent and involves extracellular signal-regulated kinase 1/2. Br J Cancer. 2008; 99:283-293. [PubMed: 18594523]

284. Sarkaria JN, Kitange GJ, James CD, Plummer R, Calvert H, Weller M, Wick W. Mechanisms of chemoresistance to alkylating agents in malignant glioma. Clin Cancer Res. 2008; 14:2900-2908. [PubMed: 18483356]

285. Rosell R, Cecere F, Santarpia M, Reguart N, Taron M. Predicting the outcome of chemotherapy for lung cancer. Curr Opin Pharmacol. 2006; 6:323-331. [PubMed: 16765644]

286. Jorgensen TJ. Enhancing radiosensitivity: targeting the DNA repair pathways. Cancer Biol Ther. 2009; 8:665-670. [PubMed: 19287209] 
287. Tetu B, Lacasse B, Bouchard HL, Lagace R, Huot J, Landry J. Prognostic influence of HSP-27 expression in malignant fibrous histiocytoma: a clinicopathological and immunohistochemical study. Cancer Res. 1992; 52:2325-2328. [PubMed: 1313743]

288. Huot J, Roy G, Lambert H, Chretien P, Landry J. Increased survival after treatments with anticancer agents of Chinese hamster cells expressing the human Mr 27,000 heat shock protein. Cancer Res. 1991; 51:5245-5252. [PubMed: 1913647]

289. Lee AS. The glucose-regulated proteins: stress induction and clinical applications. Trends Biochem Sci. 2001; 26:504-510. [PubMed: 11504627]

290. Lee E, Nichols P, Spicer D, Groshen S, Yu MC, Lee AS. GRP78 as a novel predictor of responsiveness to chemotherapy in breast cancer. Cancer Res. 2006; 66:7849-7853. [PubMed: 16912156]

291. Ling V, Thompson L. Reduced permeability in CHO cells as a mechanism of resistance to colchicine. J Cell Physiol. 1974; 83:103-116. [PubMed: 4855907]

292. Keizer HG, Schuurhuis GJ, Broxterman HJ, Lankelma J, Schoonen WG, van Rijn J, Pinedo HM, Joenje H. Correlation of multidrug resistance with decreased drug accumulation, altered subcellular drug distribution, and increased P-glycoprotein expression in cultured SW-1573 human lung tumor cells. Cancer Res. 1989; 49:2988-2993. [PubMed: 2566376]

293. Luna MC, Wong S, Gomer CJ. Photodynamic therapy mediated induction of early response genes. Cancer Res. 1994; 54:1374-1380. [PubMed: 8118827]

294. Øyan AM, Anensen N, Bø TH, Stordrange L, Jonassen I, Bruserud Ø, Kalland KH, Gjertsen BT. Genes of cell-cell interactions chemotherapy detoxification and apoptosis are induced during chemotherapy of acute myeloid leukemia. BMC Cancer. 2009; 9:77. [PubMed: 19265549]

295. Jones HA, Hahn SM, Bernhard E, McKenna WG. Ras inhibitors and radiation therapy. Semin Radiat Oncol. 2001; 11:328-337. [PubMed: 11677657]

296. Andrews P, Albright K. Mitochondrial defects in cis-diamminedichloro-platinum(II)-resistant human ovarian carcinoma cell lines. Cancer Res. 1992; 52:1895-1901. [PubMed: 1551118]

297. Hazlehurst L, Damiano J, Buyuksal I, Pledger W, Dalton W. Adhesion to fibronectin via $\beta 1$ integrins regulates $\mathrm{p} 27^{\mathrm{kip} 1}$ levels and contributes to cell adhesion mediated drug resistance (CAM-DR). Oncogene. 2000; 19:4319-4327. [PubMed: 10980607]

298. Puchner M, Giese A. Tamoxifen-resistant glioma-cell sub-populations are characterized by increased migration and proliferation. Int J Cancer. 2000; 86:468-473. [PubMed: 10797257]

299. Liang Y, Meleady P, Cleary I, McDonnell S, Connolly L, Clynes M. Selection with melphalan or paclitaxel (Taxol) yields variants with different patterns of multidrug resistance, integrin expression and in vitro invasiveness. Cancer. 2001; 37:1041-1052.

300. Tsujimoto Y. Stress-resistance conferred by high level of bcl-2 alpha protein in human B lymphoblastoid cell. Oncogene. 1989; 4:1331-1336. [PubMed: 2554236]

301. Jansen B, Schlagbauer-Wadl H, Brown B, Bryan R, van Elsas A, Muller M, Wolff K, Eichler H, Pehamberger H. Bcl-2 antisense therapy chemosensitizes human melanoma in SCID mice. Nat Med. 1998; 4:232-234. [PubMed: 9461199]

302. Strano S, Dell'Orso S, Di Agostino S, Fontemaggi G, Sacchi A, Blandino G. Mutant p53: an oncogenic transcription factor. Oncogene. 2007; 26:2212-2219. [PubMed: 17401430]

303. Bichat F, Mouawad R, Solis-Recendez G, Khayat D, Bastian G. Cytoskeleton alteration in MCF7R cells, a multidrug resistant human breast cancer cell line. Anticancer Res. 1997; 17:3393-3401. [PubMed: 9413178]

304. Gilchrist A, Meuser R, Turchinsky J, Shaw A, Pasdar M, Dixon W. Cell adhesion-mediated transformation of a human SCLC cell line is associated with the development of a normal phenotype. Exp Cell Res. 2002; 276:63-78. [PubMed: 11978009]

305. Conforti G, Codegoni A, Scanziani E, Dolfini E, Dasdia T, Calza M, Caniatti M, Broggini M. Different vimentin expression in two clones derived from a human colocarcinoma cell line (LoVo) showing different sensitivity to doxorubicin. Br J Cancer. 1995; 71:505-11. [PubMed: 7880731]

306. Byun Y, Chen F, Chang R, Trivedi M, Green K, Cryns V. Caspase cleavage of vimentin disrupts intermediate filaments and promotes apoptosis. Cell Death Differ. 2001; 8:443-450. [PubMed: $11423904]$ 


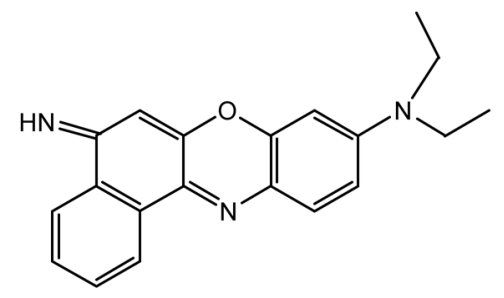

Nile Blue A

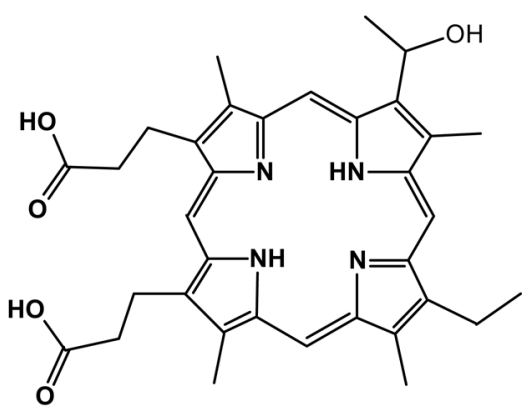

PII

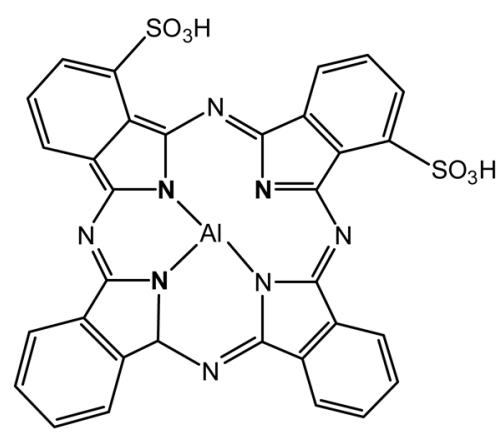

AlPCS4

Figure 1.

PS with different intracellular localization [16] employed to induce PDT-resistant variants. 

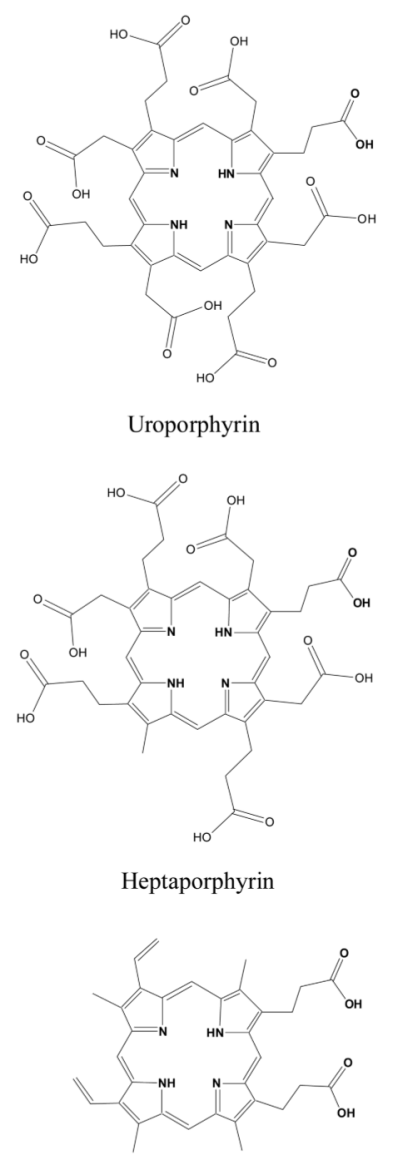

Protoporphyrin

Figure 2.

Porphyrins synthesized from ALA in LM3 cells and its ALA-PDT derived resistant clones isolated by Casas et al. [7]. 


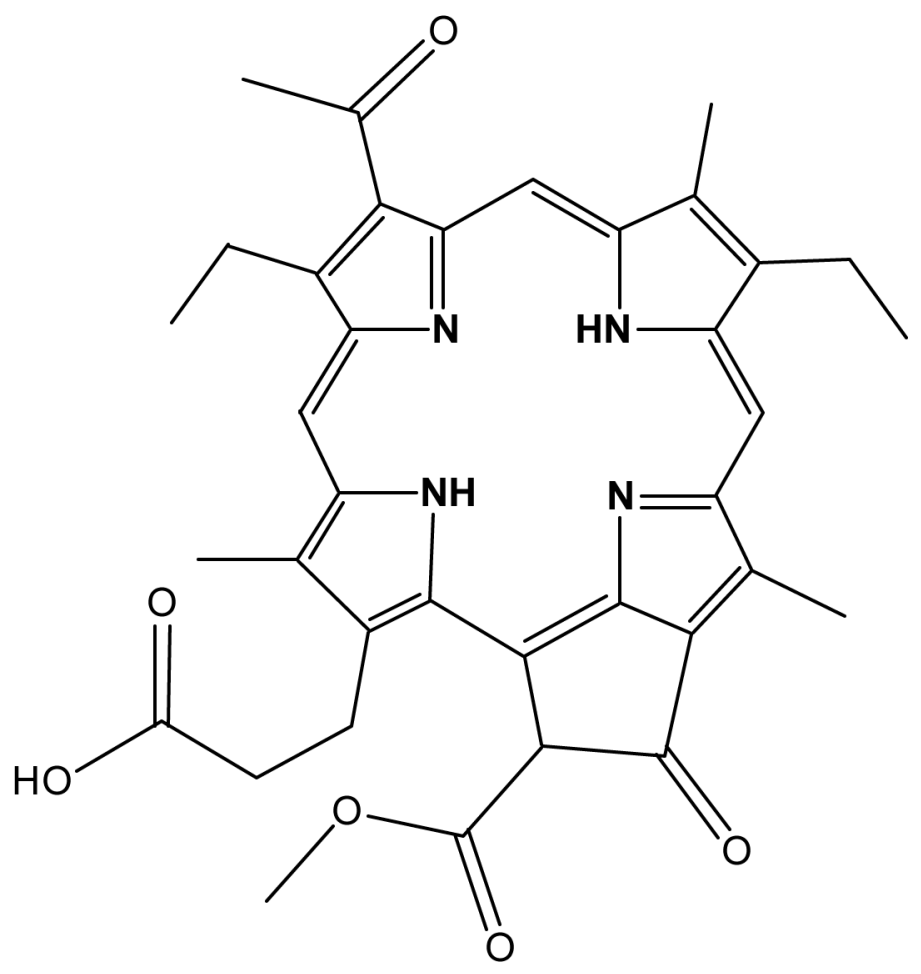

\section{TOOKAD}

Figure 3.

Structure of TOOKAD, a vascular-targeted PS found to indirectly overcome MDR resistance in experimental tumors [59]. 

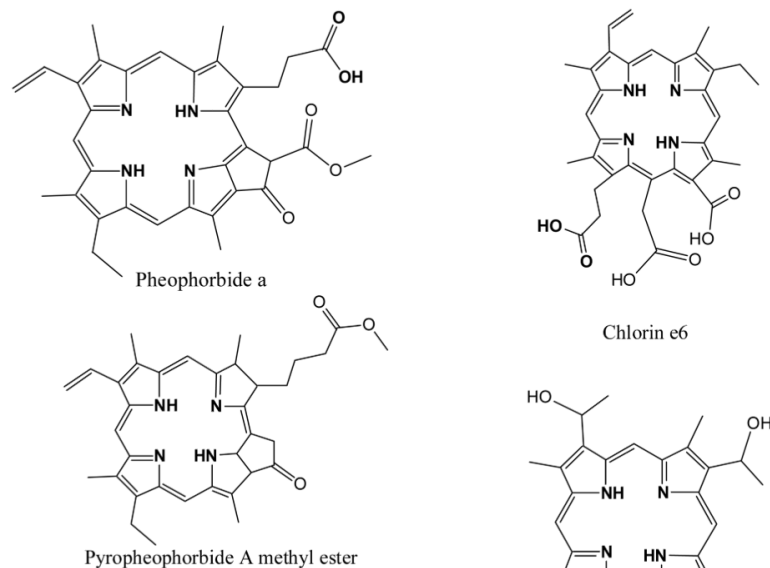

Chlorin e6
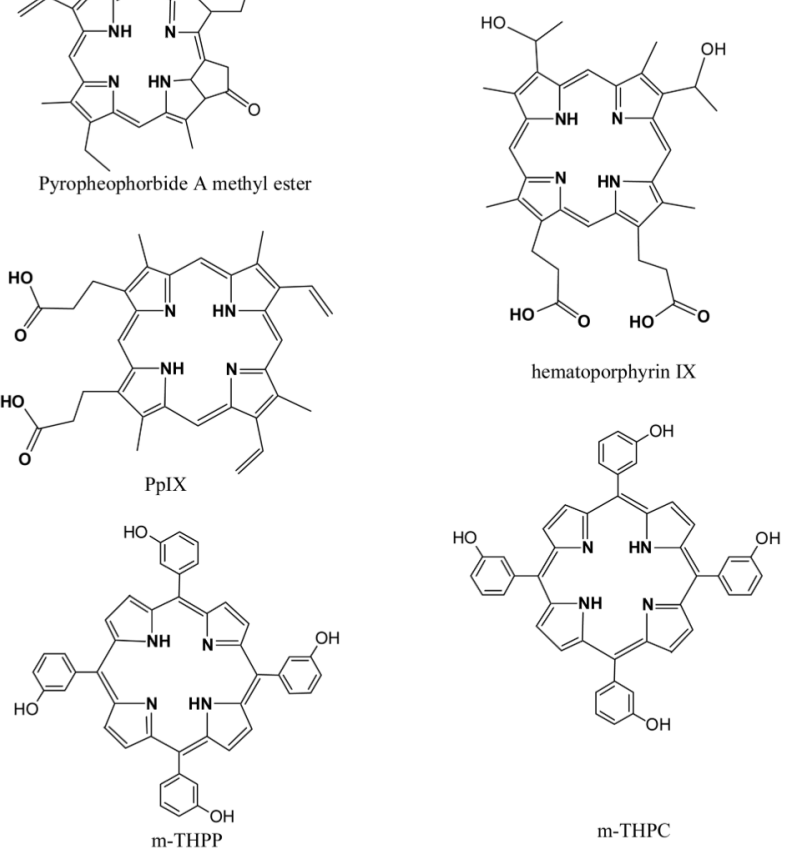

Figure 4.

PS tested by Robey et al. [51, 69] as putative ABCG2 transporter substrates in NCI-H1650 MX50 bronchoalveolar carcinoma cells. 


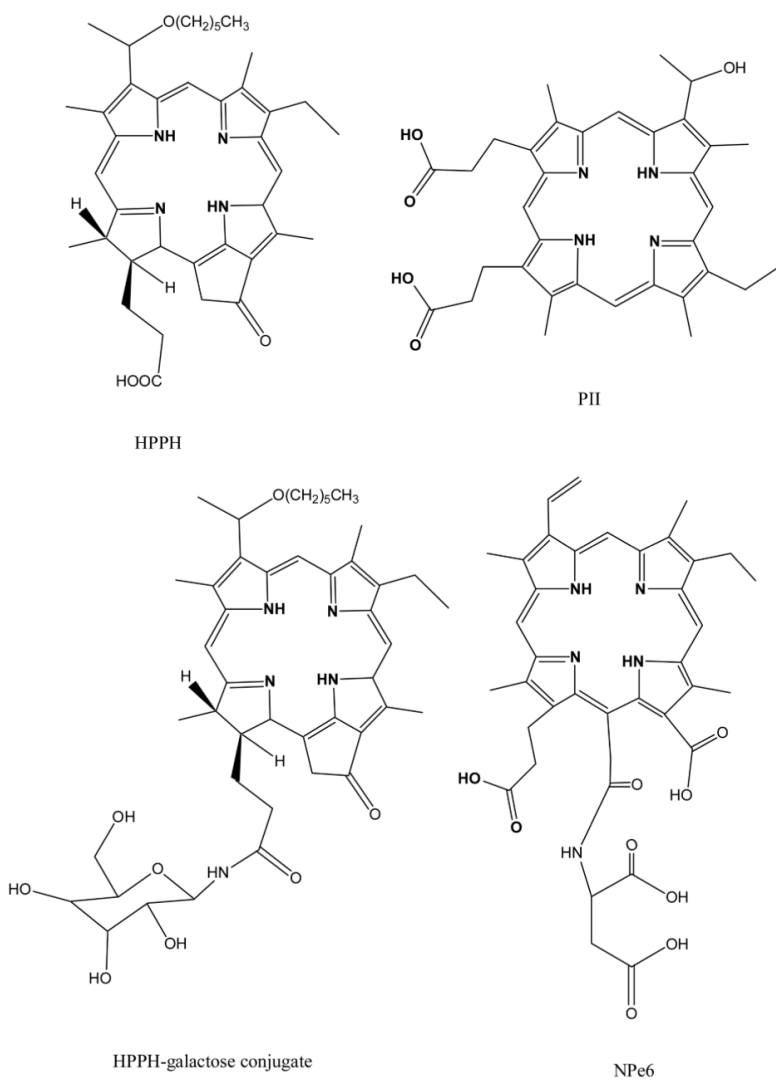

Figure 5.

PS tested by Liu et al.. [71] as putative ABCG2 transporter substrates in Colo 26 colon carcinoma cells, and by Usuda et al. [72] in epidermoid carcinoma A431 cells. 

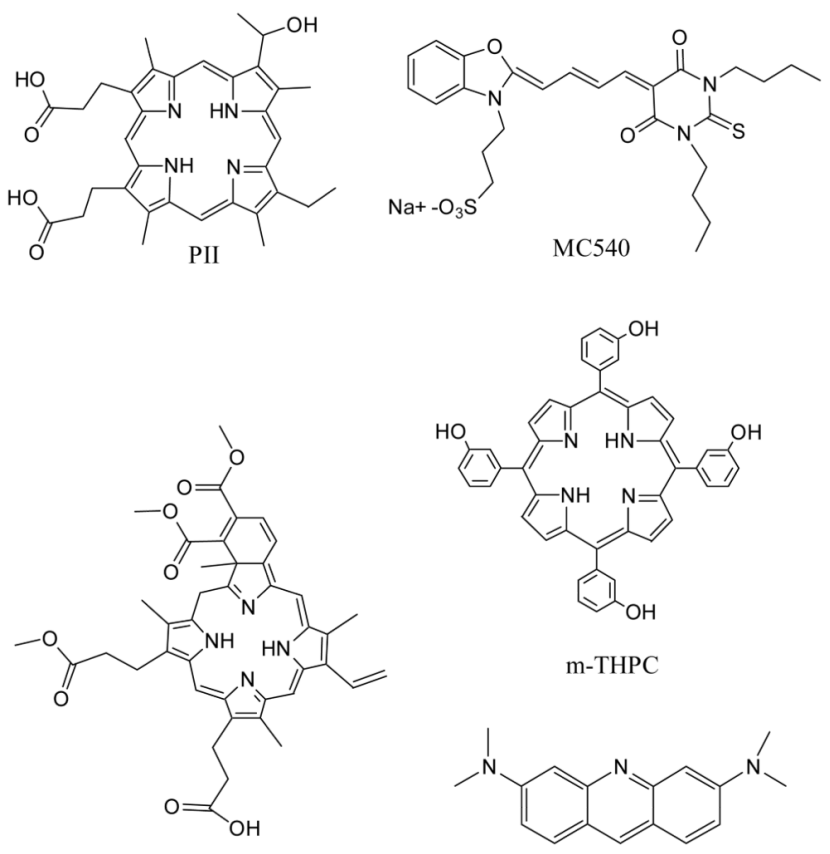

BPD-MA

Acridine orange

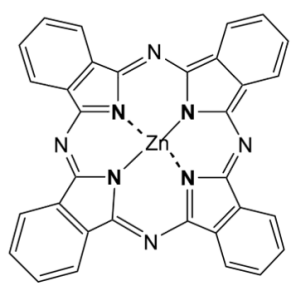

$\mathrm{Zn}-\mathrm{PC}$

Figure 6.

PS employed by Rodriguez et al. [107] and Espada et al. [96] in PDT studies of Rastransfected cells. 


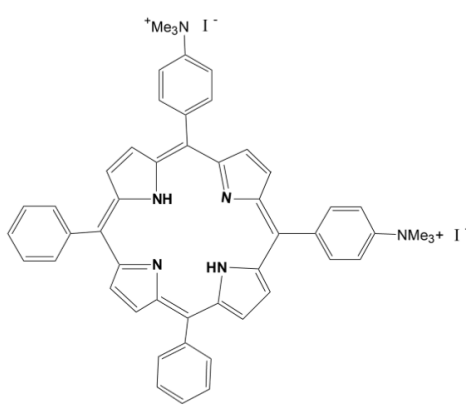

DADP-a (mitochondria)

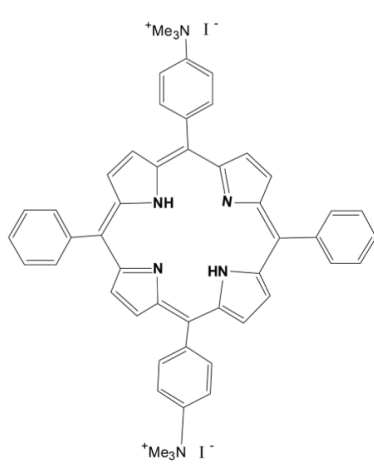

DADP-o (lysosomes)

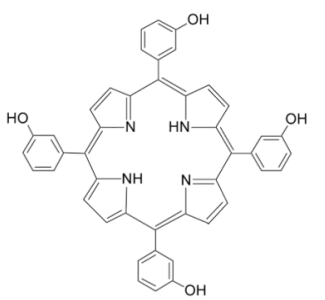

m-THPC (ER)
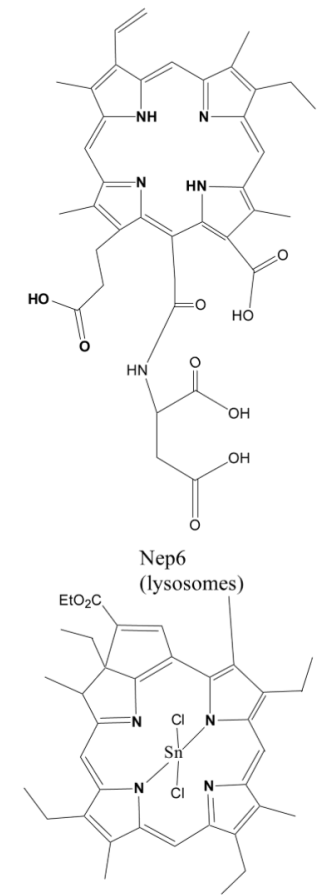

SnET2 (Lysosomes and ER)

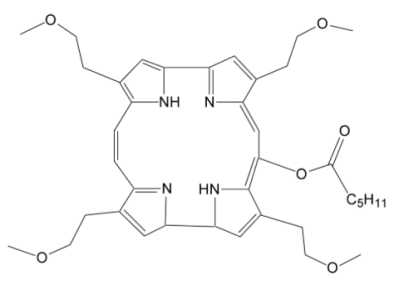

CPO (ER)

Figure 7.

PS structures employed by Kessel group with different organelle localization, but all of them leading to apoptotic cell death. 

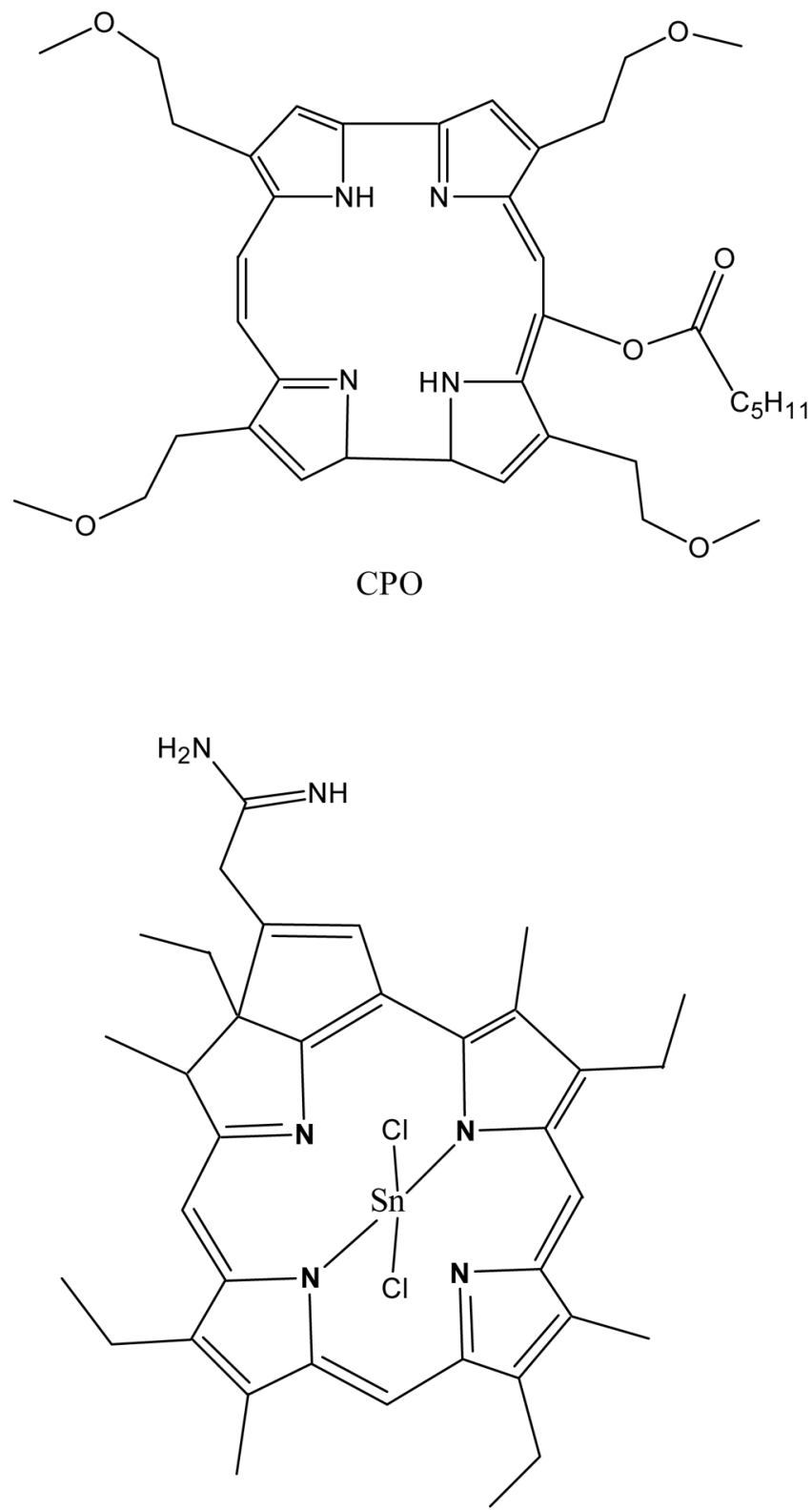

SnOPA

Figure 8.

Structures of two PS having affinity for plasma membranes, leading to a delayed apoptosis [110]. 

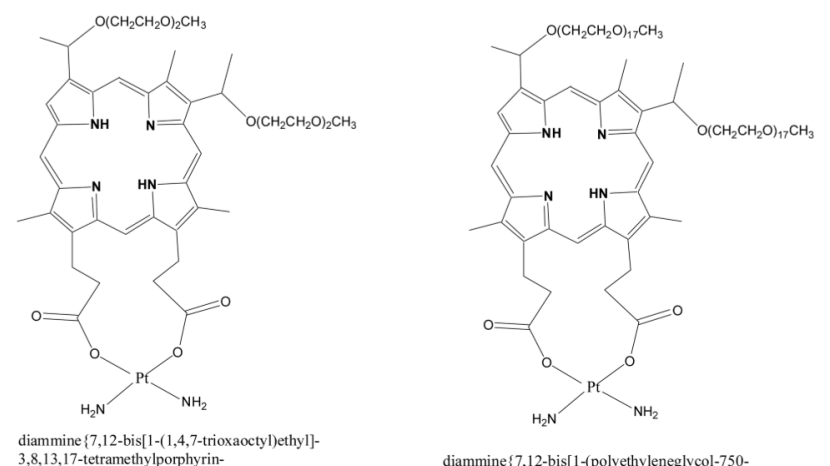
2.18-dipropionato platinum(II)

diammine $\{7,12$-bis $[1$-(polyethyleneglycol-750-
monomethylether-1-yl)ethyl] $3,3,8,13,17$-tetramethylporphyrin2,18-dipropionato ; platinum(II)
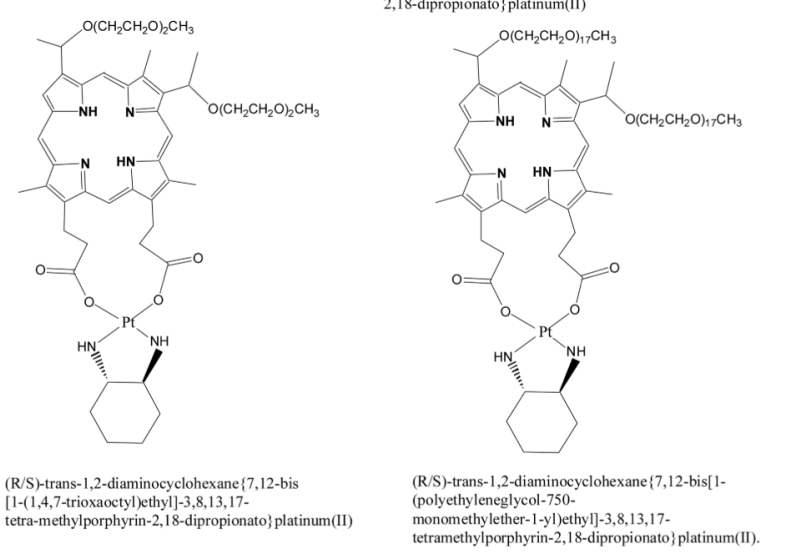

Figure 9.

Hematoporphyrin-platinum(II) conjugates synthesised by Lottner [249]. 


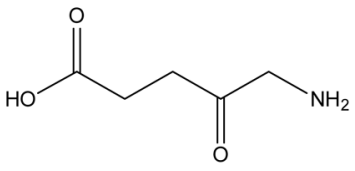

ALA

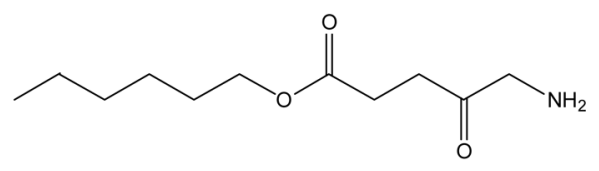

Hexyl-ALA

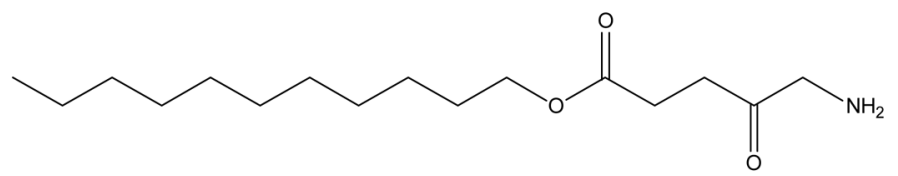

Undecanoyl-ALA

Figure 10.

ALA derived esters found to be cross resistant to ALA-PDT derived resistant cells [7]. 


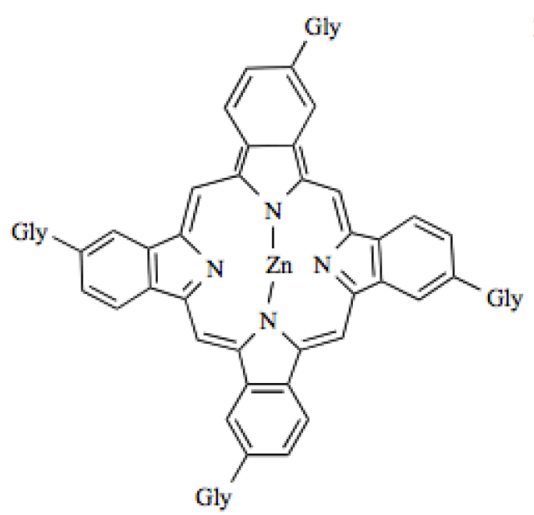

PHP

TGly

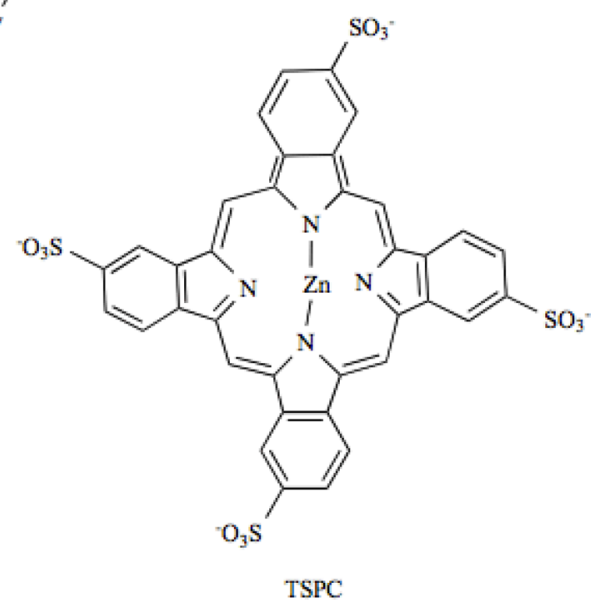

Figure 11.

Anionic PS cross resistant when employed in PDT of cell lines resistant to PHP-PDT treatment [4]. 

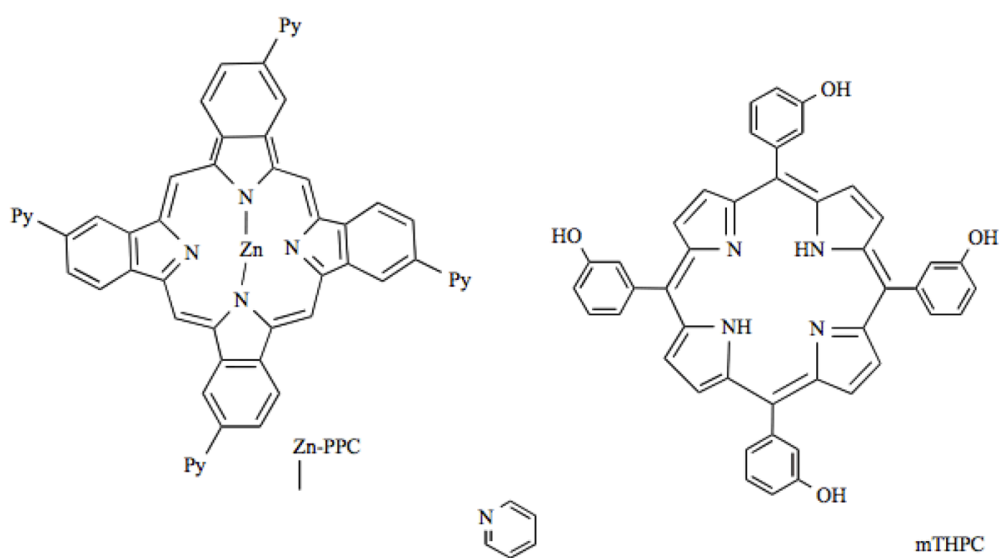

Figure 12.

Cationic and neutral PS not cross resistant when employed in PDT of cell lines resistant to Zn-PCP-PDT treatment [4]. 
Table 1

HPLC Analysis Porphyrin Synthesis from ALA in LM3 Cells and ALA-PDT Resistant Clones

\begin{tabular}{lccc}
\hline & LM3 & Clone 4 & Clone 8 \\
Uroporphyrin & $53 \pm 3.2$ & $66.2 \pm 4.1$ & $74 \pm 5.4$ \\
Heptaporphyrin & $3.6 \pm 0.1$ & $8.5 \pm 0.6$ & $4.7 \pm 0.2$ \\
Protoporphyrin & $43.4 \pm 2.6$ & $25.3 \pm 1.3$ & $21.3 \pm 1.5$ \\
\hline
\end{tabular}

Porphyrins synthesized after 3-hr of ALA exposure, expressed as percentage of the total porphyrins (Taken from [7]). 
Table 2

Changes on Gene Expression Induced After PDT Treatment

\begin{tabular}{|c|c|c|c|}
\hline Gene & PDT-Photosensitizer & Effect & Reference \\
\hline \multicolumn{4}{|l|}{ Early response genes } \\
\hline c-FOS, c-JUN, FOSB, p55-c-fos & ALA-PDT & Upregulation & $11,91,92$ \\
\hline FOSB, c-JUN & Hypericin-PDT & Upregulation & 90 \\
\hline c-MYC & ALA-PDT & Downregulation & 11 \\
\hline c-FOS & PII-PDT & Upregulation & 86 \\
\hline ETR101 & ALA-PDT & Upregulation & 92 \\
\hline \multicolumn{4}{|l|}{ Kinases } \\
\hline JNK (c-Jun N-terminal Kinase) & Pheophorbide-PDT & Upregulation & 56 \\
\hline DUSP1 (the dual specificity phosphatase 1 ) & ALA-PDT & Upregulation & 92 \\
\hline DUSP1 & Hypericin-PDT & Upregulation & 90,92 \\
\hline Histones $\mathrm{H} 2$ and $\mathrm{H} 3$ & Hypericin-PDT & Upregulation & 90,99 \\
\hline GDF15 (growth and differentiation factor 15) & ALA-PDT & Upregulation & 92 \\
\hline
\end{tabular}


Table 3

Summary of the Role of the Different Apoptotic and Antiapoptotic Proteins in PDT resistance

\begin{tabular}{|l|l|l|}
\hline & Impact on PDT resistance & References \\
\hline Apoptotic proteins & \multicolumn{3}{|l|}{} \\
\hline Mitochondia/ER targeted PDT & $\downarrow$ Bcl-2 and PDT resistance & $123,124,135$ \\
\hline Bcl-2 overexpressed & PDT resistance & $120,126,127,137$ \\
\hline Bcl-2 blockage & $\downarrow$ PDT resistance & 128,124 \\
\hline Proapoptotic proteins & \multicolumn{2}{|l}{} \\
\hline Lysosomal targeted PDT & Bid and PDT resistance & 36 \\
\hline P53 overexpressed & $\downarrow$ PDT resistance & $128,141,142,143$ \\
\hline Bax blockage & PDT resistance & 134 \\
\hline Bid blockage & $\uparrow$ PDT resistance & 136 \\
\hline
\end{tabular}


Table 4

Cells Resistant to Chemotherapy, Radiotherapy and Hyperthermia Challenged Against PDT

\begin{tabular}{|c|c|c|c|}
\hline Cell type and resistance & Challenge (PDT) & Response & Reference \\
\hline Heat resistant mouse radiation-induced fibrosarcoma cells & PII & NR & [173] \\
\hline Melanoma MDR+ & Anthrapyrazole PD 110095 & $\mathrm{CR}$ & [267] \\
\hline Melanoma MDR+ & Rhodamine & $\mathrm{CR}$ & [268] \\
\hline Hamster ovary MDR+ & PII & $\mathrm{CR}$ & [5] \\
\hline Hamster ovary MDR+ & Hematoporphyrin Derivative & $\mathrm{CR}$ & [269] \\
\hline Breast cancer DXR resistant MDR + & ALA & $\mathrm{CR}$ & [55] \\
\hline Breast cancer DXR resistant & m-THPC & NR & {$[52]$} \\
\hline Leukemic cells with mdr-1 gene transfected & ALA & NR & {$[101]$} \\
\hline Leukemic cells MDR induced & ALA & NR & [101] \\
\hline Leukemia cells resistant to Vinblastine and Vincristine & BPD & NR & [270] \\
\hline Bladder, mitomycin c resistant & ALA & NR & [246] \\
\hline Melanoma, leukemia, lymphoma, DXR & A1S2PC & NR & [271] \\
\hline Osteosarcoma MDR+ & Acridine Orange & $\mathrm{NR}$ & [272] \\
\hline Five lines MDR+ & Methylene Blue & NR & [273] \\
\hline Leukemic, MDR+ & MC540 & NR & [264] \\
\hline Murine leukemia, MDR & Mesoporphyrin & NR & {$[50]$} \\
\hline Murine leukemia, MDR & Copper benzochlorin iminium salt & $\mathrm{CR}$ & [41] \\
\hline Erythroleukemic cells, MDR & A1S2PC & NR & [274] \\
\hline Heat resistant hamster fibroblasts & PII & NR & [173] \\
\hline Colon carcinoma, MDR & TOOKAD vascular targeted- PDT & $\mathrm{CR}$ in vitro & [59] \\
\hline Colon carcinoma, MDR & TOOKAD vascular targeted- PDT & NR in vivo & [59] \\
\hline Heat resistant RIF cells & PII & NR & [173] \\
\hline Ovary cisplatin resistant $\mathrm{C} 13^{*}$ & PII & $\mathrm{CR}$ & [44] \\
\hline Melphalan-resistant and adriamycin-resistant leukemia cells & Crystal violet & $\mathrm{CR}$ & [247] \\
\hline Cisplatin-resistant small cell lung cancer & Crystal violet & NR & [247] \\
\hline $\begin{array}{l}\text { Lewis lung carcinoma cells and low metastatic angiogenesis- } \\
\text { dependent variant resistant to chemotherapy }\end{array}$ & $\begin{array}{l}\text { hematoporphyrin conjugated with antibodies to } \\
\text { VEGF }\end{array}$ & $\overline{N R}$ & [275] \\
\hline Breast carcinoma cells resistant to DXRs & $\begin{array}{l}\text { Aerosol OT-alginate nanoparticles as carriers } \\
\text { for the simultaneous cellular delivery of } \\
\text { doxorubicin and methylene blue. }\end{array}$ & NR & [276] \\
\hline $\mathrm{BALB} / \mathrm{c}$ mice bearing syngeneic JC resistant tumor $s$ & $\begin{array}{l}\text { Aerosol OT-alginate nanoparticles as carriers } \\
\text { for DXR and methylene blue. }\end{array}$ & NR & [277] \\
\hline Human uterine sarcoma cells expressing MDR1 & hexyl-ALA & Slightly CR & {$[54]$} \\
\hline Human uterine sarcoma cells expressing MDR1 & TPPS2a & $\mathrm{CR}$ & [57] \\
\hline ABCG2-transfected human embryonic kidney cells & $\begin{array}{l}\text { pheophorbide a, pyropheophorbide a methyl } \\
\text { ester, chlorin e6 and ALA }\end{array}$ & $\mathrm{CR}$ & [51] \\
\hline Human epidermoid carcinoma cells overexpressing ABCG2 & PII & $\mathrm{CR}$ & [72] \\
\hline Human epidermoid carcinoma cells overexpressing ABCG2 & NPe6 & NR & [72] \\
\hline ABCG2-transfected human embryonic kidney cells & m-THPC & NR & [51] \\
\hline
\end{tabular}




\begin{tabular}{|c|c|c|c|}
\hline Cell type and resistance & Challenge (PDT) & Response & Reference \\
\hline Human hepatoma cell line +MDR & pheophorbide a & NR & {$[56]$} \\
\hline
\end{tabular}

CR: cross resistant, NR: non-resistant. 
Table 5

Cells Resistant to PDT Challenged Against Chemotherapy, Radiotherapy or Hyperthermia

\begin{tabular}{|c|c|c|c|}
\hline Resistance agent & Challenge & Response & Reference \\
\hline m-THPC-PDT & Chemotherapy & NR & {$[278]$} \\
\hline m-THPC-PDT & Ionizing radiation & NR & {$[278]$} \\
\hline PII-PDT & Cisplatin & CR & {$[48]$} \\
\hline PII-PDT & Doxorubicin & CR & {$[250]$} \\
\hline PII-PDT & Doxorubicin & NR & {$[5]$} \\
\hline PII-PDT & Y-irradiation & Slight CR & {$[6]$} \\
\hline PII-PDT & Hyperthermia & NR & {$[6]$} \\
\hline PII-PDT & UV & CR & {$[81]$} \\
\hline PHP-PDT and Zn-PCP-PDT & UVA, UVC & NR & {$[4]$} \\
\hline PHP-PDT and Zn-PCP-PDT & Hyperthermia & NR & {$[4]$} \\
\hline PHP-PDT and Zn-PCP-PDT & Cisplatin & NR & {$[4]$} \\
\hline HT29 cells resistant to PII, Nile blue A and AlPcS4- PDT. & Cisplatin & NR & {$[125]$} \\
\hline HT29 cells resistant to PII, Nile blue A and AlPcS4- PDT. & UVA light & CR & {$[253]$} \\
\hline HT29 cells resistant to PII, Nile blue A and AlPcS4- PDT. & UVC light & NR & {$[253]$} \\
\hline
\end{tabular}

CR: cross resistant, NR: non-resistant. 
Table 6

Cells Resistant to PDT Challenged Against PDT with a Different PS

\begin{tabular}{|c|c|c|c|}
\hline Resistance agent (PDT) & Challenge (PDT) & Response & Reference \\
\hline PII (short exposure)-PDT & PII (long exposure)-PDT & $\mathrm{NR}$ & {$[6]$} \\
\hline PII (long exposure)-PDT & PII (short exposure)-PDT & $\mathrm{CR}$ & {$[6]$} \\
\hline PHP (short exposure)-PDT & PHP (long exposure)-PDT & $\mathrm{CR}$ & {$[4]$} \\
\hline Zn-PCPP (short exposure)-PDT & Zn-PCP (long exposure)-PDT & $\mathrm{NR}$ & {$[4]$} \\
\hline PHP-PDT & PpIX, TSPC TGly-PDT & $\mathrm{CR}$ & {$[4]$} \\
\hline PHP-PDT & Zn-PCP, m-THPC, mTPyP, PPIX-PDT & $\mathrm{NR}$ & {$[4]$} \\
\hline Zn-PCP-PDT & PpIX, PHP, TSPC, TGly, m- THPC-PDT & $\mathrm{NR}$ & {$[4]$} \\
\hline Zn-PCP-PDT and PHP-PDT & ALA-PDT & $\mathrm{NR}$ & {$[4]$} \\
\hline PII-PDT & PpIX-PDT & $\mathrm{CR}$ & {$[26]$} \\
\hline PII-PDT & ALA-PDT & $\mathrm{NR}$ & {$[26]$} \\
\hline ALA-PDT & MC540 and BPD-MA-PDT & $\mathrm{NR}$ & {$[7]$} \\
\hline ALA-PDT & PII-PDT & Slight CR & {$[7]$} \\
\hline ALA-PDT & ALA esters-PDT & $\mathrm{CR}$ & {$[7]$} \\
\hline PII-PDT & Exogenous PpIX-PDT & $\mathrm{CR}$ & {$[26]$} \\
\hline PII-PDT & ALA-PDT & $\mathrm{NR}$ & {$[26]$} \\
\hline
\end{tabular}

CR: cross resistant, NR: non-resistant. 
Table 7

Mechanisms of Resistance to PDT and to Chemotherapy

\begin{tabular}{|c|c|}
\hline PDT resistant cells & Chemoresistant cells \\
\hline $\begin{array}{c}\text { Increased cell spreading }[7,44] . \\
\text { Increased cell size and protein content }[6,7] .\end{array}$ & $\begin{array}{l}\text { Increased cell size in samples from patients with chemoresistant } \\
\text { SCLC [204]. }\end{array}$ \\
\hline Increased ploidy in RIF-1 PDT resistant variants [6]. & $\begin{array}{l}\text { Polyploidization as a mechanism of resistance to chemotherapy, } \\
\text { mutagenic drugs and ionizing radiation }[279,280] \text {. }\end{array}$ \\
\hline $\begin{array}{l}\text { Cells transfected with glutathione-associated enzymes protects from } \\
\text { PDT-damage [43]. } \\
\text { Glutathione content per cell is increased in some PDT resistant cells } \\
{[6,7] .} \\
\text { SOD2 upregulated after ALA-PDT [92]. }\end{array}$ & $\begin{array}{c}\text { Elevatated levels of glutathione-associated enzymes [281]. } \\
\text { Elevated GSH synthesis associated with resistance [282]. } \\
\text { Overexpression of MnSOD as a mechanism increasing resistance to } \\
\text { apoptosis in cancer cells [283]. }\end{array}$ \\
\hline $\begin{array}{c}\text { Increased capacity for viral DNA synthesis was observed in the } \\
\text { RIF-8A PDT resistant cells [81]. }\end{array}$ & $\begin{array}{l}\text { DNA repair as a resistance mechanism to alkylating agents and other } \\
\text { drugs }[284,285] \text {, as well as radioresistance [286]. }\end{array}$ \\
\hline $\begin{array}{l}\text { Increased mRNA and expression of several HSPs }[6,43,174] \text { and } \\
\text { GRPs [169]. }\end{array}$ & HSPs and GRPs associated with chemoresistance [287-290]. \\
\hline $\begin{array}{l}\text { No demonstrated overexpression of P-gp in PDT resistant cells, but } \\
\text { many MDR+ cell lines are cross-resistant to PDT (see Table 4). } \\
\text { Subcellular distribution of PS modified in P- gp expressing cells [58]. }\end{array}$ & $\begin{array}{l}\text { P-gp associated to MDR resistant tumors [291], correlated to } \\
\text { decreased intracellular drug accumulation and subcellular } \\
\text { localization [292]. }\end{array}$ \\
\hline $\begin{array}{l}\text { Early response genes and signal transduction pathways activated after } \\
\text { PDT }[11,87-90,293] \text {. }\end{array}$ & $\begin{array}{l}\text { Early response genes and signal transduction pathways activated } \\
\text { after chemotherapy [294]. }\end{array}$ \\
\hline $\begin{array}{l}\text { Ras transfected cells are resistant to PDT employing ALA [107] and } \\
\text { other PS [96]. }\end{array}$ & $\begin{array}{l}\text { Ras oncogene involved in chemo and radio resistance }[104,105 \text {, } \\
295] .\end{array}$ \\
\hline $\begin{array}{c}\text { ABCG2 efflux PpIX [67]. Some ABCG2 overexpressing cells are } \\
\text { resistant to PDT [51,72]. }\end{array}$ & $\begin{array}{l}\text { ABCG2 effluxes mitoxantrone, camptothecin-derived and } \\
\text { indolocarbazole topoisomerase I inhibitors, methotrexate, } \\
\text { flavopiridol, and quinazoline ErbB1 inhibitors [65]. }\end{array}$ \\
\hline $\begin{array}{c}\text { RIF-1 PII-PDT resistant cells have smaller mitochondria, produce } \\
\text { more ATP, have higher succinate dehydrogenase activity, but } \\
\text { diminished membrane potential [44]. } \\
\text { A cell line lacking mitDNA was resistant to PDT [41]. }\end{array}$ & $\begin{array}{c}\text { The ovarian carcinoma cell C13* cisplatin-resistant variant has } \\
\text { similar features [296]. } \\
\text { A cell line lacking mitDNA was resistant to DXR but not to } \\
\text { alkylating agents [42]. }\end{array}$ \\
\hline $\begin{array}{c}\text { PDT modifies cell adhesion, invasiveness and metastasis }[186,189, \\
190,197] .\end{array}$ & $\begin{array}{c}\text { Cell adhesion-mediated drug resistance [297]. } \\
\text { Increased adhesion to ECM proteins, decreased or increased } \\
\text { expression of integrins, increased motility, invasiveness and } \\
\text { metastasis [297-299]. }\end{array}$ \\
\hline $\begin{array}{l}\text { Transfection of Bcl-2 confers resistance to PDT [126, 127]. } \\
\text { Wild-type p53 transfected cells are more sensitive to PDT [128, 140]. }\end{array}$ & $\begin{array}{c}\text { Bcl-2 overexpression related to chemoresistance [300]. } \\
\text { Bcl-2 antisense therapy chemosensitizes cells [301]. } \\
\text { P53 mutations contribute to resistance to chemo- and radiotherapy } \\
\text { [302]. }\end{array}$ \\
\hline $\begin{array}{l}\text { PDT resistant cells show signs of cytoskeleton disorganization [197]. } \\
\text { Vimentin confers resistance impairing nuclear apoptosis after PDT } \\
\text { [200]. }\end{array}$ & $\begin{array}{c}\text { Cytoskeleton alterations are present in MDR cells [303]. } \\
\text { Epithelial-mesenchymal conversion involved in invasiveness and } \\
\text { metastasis [304]. Vimentin can be considered as a marker of } \\
\text { resistance [305]. Caspase cleavage of vimentin promotes apoptosis } \\
\text { [306]. }\end{array}$ \\
\hline $\begin{array}{l}\text { Indirect evidence of the role of COX-2 in photoresistance such as } \\
\text { combination of PDT with COX-2 inhibitors, resulting in enhanced } \\
\text { photodamage }[26,211,214] \text {. }\end{array}$ & $\begin{array}{l}\text { COX-2 is associated by resistance to standard cancer treatment } \\
\qquad[210] .\end{array}$ \\
\hline $\begin{array}{l}\text { Bhowmick [231] et al. reported evidence for increased tumor cell } \\
\text { resistance due to iNOS upregulation in a PDT model. }\end{array}$ & $\begin{array}{l}\text { NO involved in resistance to radiotherapy [219]. } \\
\text { Blocking NOS reverses apoptosis [222]. }\end{array}$ \\
\hline $\begin{array}{l}\text { PDT-induced tissue hypoxia as a result of vascular damage and } \\
\text { photochemical oxygen consumption limit its efficacy [240]. } \\
\text { PDT induce stabilization of (HIF1)-alpha [131, 241]. }\end{array}$ & $\begin{array}{l}\text { Hypoxia reduces the effectiveness of radiotherapy and some } \mathrm{O}_{2-} \\
\text { dependent cytotoxic agents [240]. }\end{array}$ \\
\hline $\begin{array}{l}\text { Survivin was found to be target for PDT, but there are still no reports } \\
\text { on upregulation in PDT resistant cells }[236,239,238] .\end{array}$ & $\begin{array}{l}\text { In various tumors, highsurvivin levels are correlated with poor } \\
\text { prognosis, decreased apoptosis, increased angiogenesis, and } \\
\text { chemoresistance in cancercells [233, 234]. }\end{array}$ \\
\hline
\end{tabular}

